\title{
Targeting the Ubiquitin-Proteasome System for Cancer Therapeutics by Small-Molecule Inhibitors
}

\author{
Gabriel LaPlante ${ }^{1}$ and Wei Zhang ${ }^{1,2, *}$ \\ 1 Department of Molecular and Cellular Biology, College of Biological Science, University of Guelph, \\ 50 Stone Rd E, Guelph, ON N1G2W1, Canada; glaplant@uoguelph.ca \\ 2 CIFAR Azrieli Global Scholars Program, Canadian Institute for Advanced Research, MaRS Centre West \\ Tower, 661 University Avenue, Toronto, ON M5G1M1, Canada \\ * Correspondence: weizhang@uoguelph.ca
}

check for updates

Citation: LaPlante, G.; Zhang, W. Targeting the Ubiquitin-Proteasome System for Cancer Therapeutics by Small-Molecule Inhibitors. Cancers 2021, 13, 3079. https://doi.org/ 10.3390/cancers13123079

Academic Editors: Alberto Inga and Lucília Saraiva

Received: 27 May 2021

Accepted: 17 June 2021

Published: 20 June 2021

Publisher's Note: MDPI stays neutral with regard to jurisdictional claims in published maps and institutional affiliations.

Copyright: (c) 2021 by the authors. Licensee MDPI, Basel, Switzerland. This article is an open access article distributed under the terms and conditions of the Creative Commons Attribution (CC BY) license (https:// creativecommons.org/licenses/by/ $4.0 /)$.
Simple Summary: The ubiquitin-proteasome system regulates multiple facets of protein homeostasis to modulate signal transduction in numerous biological processes. Not surprisingly, dysregulation of this delicately balanced system is frequently observed in cancer progression. In the past two decades, researchers in both academia and industry have made significant progress in developing small-molecule inhibitors targeting various components in the ubiquitin-proteasome system for cancer therapy. Here, we aim to provide a comprehensive summary of these efforts. Additionally, we overview the advancements of targeted protein degradation, a recently emerging drug discovery concept in cancer therapy.

Abstract: The ubiquitin-proteasome system (UPS) is a critical regulator of cellular protein levels and activity. It is, therefore, not surprising that its dysregulation is implicated in numerous human diseases, including many types of cancer. Moreover, since cancer cells exhibit increased rates of protein turnover, their heightened dependence on the UPS makes it an attractive target for inhibition via targeted therapeutics. Indeed, the clinical application of proteasome inhibitors in treatment of multiple myeloma has been very successful, stimulating the development of small-molecule inhibitors targeting other UPS components. On the other hand, while the discovery of potent and selective chemical compounds can be both challenging and time consuming, the area of targeted protein degradation through utilization of the UPS machinery has seen promising developments in recent years. The repertoire of proteolysis-targeting chimeras (PROTACs), which employ E3 ligases for the degradation of cancer-related proteins via the proteasome, continues to grow. In this review, we will provide a thorough overview of small-molecule UPS inhibitors and highlight advancements in the development of targeted protein degradation strategies for cancer therapeutics.

Keywords: ubiquitin (Ub); ubiquitin-proteasome system (UPS); cancer; small-molecule; proteolysistargeting chimera (PROTAC); E3 ligase; deubiquitinase (DUB)

\section{Introduction}

The ubiquitin-proteasome system (UPS) is vital for protein homeostasis and is implicated in many cellular processes, including DNA repair [1], endocytic trafficking [2], and the immune response [3]. The wide range of activities regulated by the UPS stems from the remarkable specificity and diversity of signal transduction events enabled by the process of ubiquitination. Ubiquitination is a post-translational protein modification involving the covalent attachment of ubiquitin ( $\mathrm{Ub})$, a highly conserved 76-amino acid polypeptide, to a substrate via the coordinated activities of a Ub-activating enzyme (E1), a Ub-conjugating enzyme (E2), and a Ub ligase (E3) (Figure 1) [4-6]. In the presence of ATP, $\mathrm{Ub}$ is activated by E1 before being delivered to the E2 enzyme, and this is followed by its eventual transfer to the substrate proteins, catalyzed by a E3 ligase [5,7]. Most commonly, $\mathrm{Ub}$ is reversibly conjugated either at a lysine $(\mathrm{K})$ residue or an N-terminal amino acid 
and can be attached as a single polypeptide (mono-ubiquitination) or a polymer of at least four (poly-ubiquitination) [4,7-10]. Ub itself contains seven lysines, any of which can be an attachment site for the next molecule in a poly-Ub chain. Additional layers of complexity arise by post-translational modifications and the addition of Ub-like molecules, such as NEDD8, to Ub chains [11]. The resulting diverse possibilities of mixed, branched, or modified chains provides the basis for the functional diversity of $\mathrm{Ub}$ signaling.

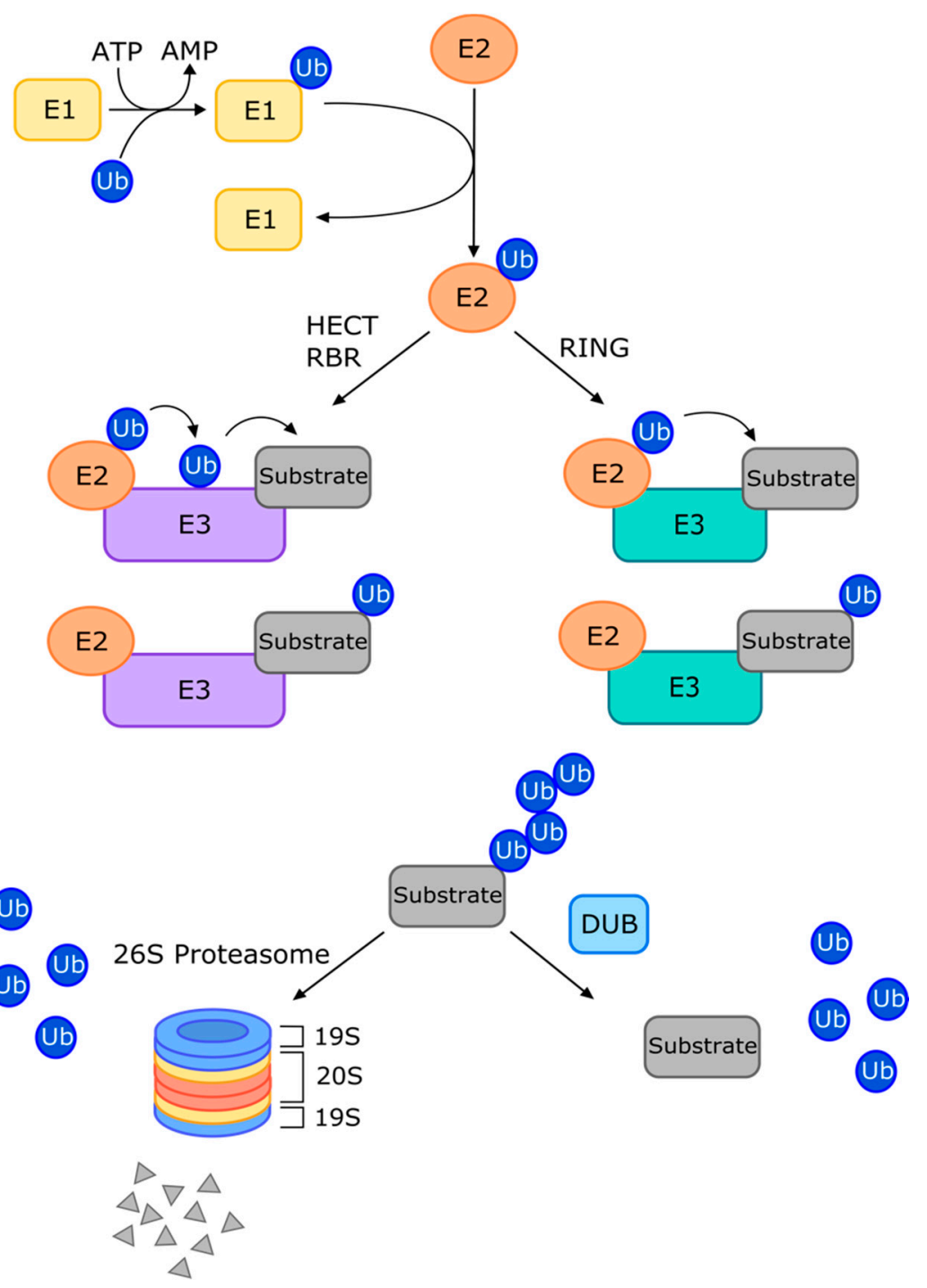

Figure 1. Overview of the ubiquitin-proteasome system (UPS). The E1, E2, E3 enzyme cascade results in the ubiquitination of a protein substrate. HECT and RBR-type E3 ligases perform a two-step ubiquitination, whereas RING E3s perform direct Ub transfer. K48-linked poly-ubiquitination results in proteasomal degradation, whereby the 19S proteasomal subunit removes $\mathrm{Ub}$ moieties prior to the substrate's proteolytic degradation by the $26 \mathrm{~S}$ subunit. DUBs can rescue substrate expression or alter cell signaling by removing $\mathrm{Ub}$ moieties. $\mathrm{Ub}$, ubiquitin; HECT, Homologous to E6-AP carboxyl terminus; RBR, RING-between-RING; RING, really interesting new gene; DUB, deubiquitinase.

The eventual fate of a ubiquitinated protein depends on the nature of the $\mathrm{Ub}$ chain. The most well-studied linkage is the K48-linked polyubiquitination, which generally targets proteins for proteasomal degradation [6]. The $26 \mathrm{~S}$ proteasome is a large protein complex consisting of the $20 \mathrm{~S}$ catalytic core and $19 \mathrm{~S}$ regulatory subunit(s) [12]. The 19S subunit cleaves the $\mathrm{Ub}$ moiety from the protein substrate and threads the unfolded protein into the catalytic core, where the substrate is degraded via chymotrypsin-like, trypsin-like, and 
caspase-like proteolysis activities $[10,12,13]$. The second-best understood linkage, K63, has important non-proteolytic roles, including functions in protein trafficking [2,14] and the DNA damage response pathways [1]. Importantly, K48 chains can also be involved in nonproteolytic functions, while K63 chains, conversely, have known proteolytic functions [7]. The other five lysine linkages (K6, K11, K27, K29, and K33) are less well-studied, although this topic has recently been comprehensively reviewed [15]. Briefly, K6-linked poly-Ub chains have been shown to be involved in autophagy and the DNA damage response; K11 chains are implicated in cell cycle regulation and proteasomal degradation or stabilization; K27 chains are important actors in the innate immune response; K29 chains are involved in cell signaling, with potentially protective roles in neurodegenerative diseases; and K33 chains have purported roles in cell signaling and protein trafficking. The diverse arsenal of $\mathrm{Ub}$ signals implies that $\mathrm{Ub}$-interacting proteins must possess some means of deciphering the code, and indeed, the eukaryotic genome contains an array of $\mathrm{Ub}$ binding domains (UBDs) that can confer linkage specificity to a Ub receptor [16]. While many UBDs are promiscuous on their own, the structural environment created between the UBD and its surrounding domains, whether on the same protein or adjacent proteins within a complex, can confer remarkable selectivity [7].

While the specific mechanism of ubiquitination can vary, the process is generally catalyzed by the $\mathrm{E} 1 \rightarrow \mathrm{E} 2 \rightarrow \mathrm{E} 3$ signaling cascade [5,7]. There are two known E1 activating enzymes, dozens of E2 enzymes, and over 600 E3 ligases encoded in the human genome [17]. The E3 ligases can be classified depending on their structural domains and mechanism of action into three major families, termed homologous to E6-AP carboxyl terminus (HECT), really interesting new gene (RING), and RING-between-RING (RBR) families [18]. Intriguingly, an additional accessory factor called an E4 enzyme can be involved in the lengthening of $\mathrm{Ub}$ chains [7]. On the other side of the spectrum, a class of enzymes called deubiquitinases (DUBs) oppose the action of the E3 ligases. DUBs can trim, edit, and remove $\mathrm{Ub}$ moieties from protein substrates, thereby preventing their degradation or altering cell signaling [19-21]. Around 100 DUB enzymes are encoded in the human genome, for which seven phylogenetically-delineated families exist: the Ub-specific proteases (USPs), Ub carboxyl-terminal hydrolases (UCHs), the otubain/ovarian-tumor-domain containing proteins (OTUs), the Machado-Joseph disease domain superfamily (MJDs), the JAB1/MPN/MOV34 proteases (JAMMs), the motif interacting with Ub-containing DUB family (MINDYs), and the zinc finger containing peptidase (ZUP1) family, which has one human representative $[5,11,22]$. Similar to other Ub-interacting proteins, DUBs contain UBDs that dictate their linkage specificity [22].

A harmonious balance between ubiquitination and deubiquitination is essential for protein homeostasis. Definitive links between aberrant $\mathrm{Ub}$ signaling and disease have been identified, and the misregulation of the UPS is a contributing factor for many types of cancers $[13,23]$. Evidence underscoring roles of the UPS in tumorigenesis, tumor metabolism, and tumor survival has been recently summarized [17]. For example, mutations in the E3 ligase F-box/WD repeat-containing protein 7 (FBXW7) can contribute to tumorigenesis through accumulation of its oncogenic targets including MYC and mTOR [24,25]. The UPS can ubiquitinate mitochondrial outer membrane proteins [26,27], turn over mitochondrial oxidative phosphorylation proteins [28], and modulate redox balance [29], all of which signal its role in regulating tumor metabolism [17]. Tumor survival is dependent on the UPS' regulation of various pro-apoptotic pathways, including modulation of TNF signaling through RIP1 ubiquitination [17,30]. Additionally, cancer cells may particularly rely on the UPS for protein homeostasis and tumor survival because of their increased rates of protein turnover [5,31]. For all of these reasons, the UPS has been identified as an attractive target for development of cancer therapeutics.

To date, the proteasome; E1, E2, E3; and DUBs have all been targeted for inhibition by small-molecule inhibitors. The early success achieved by proteasome inhibitors such as bortezomib [32] encouraged researchers to look for small-molecule inhibitors of the other UPS players. Over the past number of years, both traditional and innovative ap- 
proaches to small-molecule screens have been employed for the identification of novel chemical inhibitors [33]. Another promising strategy exploiting the UPS is targeted protein degradation, such as the proteolysis-targeting chimera (PROTAC) technology [34]. PROTAC therapeutics can utilize small-molecule "warheads" to hijack UPS machinery and selectively target proteins of interest for proteasomal degradation via their ubiquitination, offering the promise of a greatly expanded scope of druggable targets within the human proteome. Here, this review will provide an updated overview of small-molecule inhibitors of the UPS, as well as developments in targeted protein degradation and PROTAC technology, in the context of cancer therapeutics.

\section{Small-Molecule Inhibitors Targeting the UPS}

\subsection{Proteasome Inhibitors}

The proteasome was the first UPS component to achieve clinical success as a therapeutic target [32]. The high rate of protein turnover in cancer cells, paired with the marked absence of proteasome abnormalities in human cancers, indicated that cancer cells may require increased use of the proteasome [5,35]. Subsequently, proteasome inhibitors (PIs) targeting the 20S catalytic core particle, such as bortezomib [12,32], carfilzomib [36,37], oprozomib [38], and ixazomib [39], or targeting the 19S regulatory particle, such as IU1 [40], b-AP15 [41], VLX1570 [42], RA-9 [43], WP1130 [44], and RA190 [45], have been widely developed as cancer therapies (Table 1).

Bortezomib is the first and most successful of the PIs used in clinics for cancer therapy. Bortezomib downregulates NF- $k$ B signalling (activation of which has been implicated in the progression of many cancers) by reversibly binding the $20 \mathrm{~S}$ subunit active site and preventing proteasomal degradation of inhibitors of NF- $\kappa$ B (I $\kappa \mathrm{Bs})[12,35,46]$. Bortezomib was also shown to inhibit NF- $\kappa$ B activation in multiple myeloma (MM) cells via inhibition of tumor necrosis factor alpha (TNF- $\alpha$ ) [47]. Bortezomib has been approved by the U.S. Food and Drug Administration (FDA) for treatment of MM [32,48], mantle cell lymphoma (MCL), non-small-cell lung cancer (NSCLC), and pancreatic cancer [12,49-53]. However, similar to other PIs, its use is limited by adverse effects and drug resistance. For example, Bortezomib-induced peripheral neuropathy (BIPN) is a common limiting toxicity that can result in sensory alteration, motor weakness, and severe pain, sometimes permanently impairing the patient's quality of life $[54,55]$. Furthermore, acquired Bortezomib resistance is relatively common, limiting its applicability. Two separate studies revealed resistance mechanisms hinging on acquired mutations in the proteasome $\beta 5$-subunit (PSMB5) protein that impacted Bortezomib binding to the proteasome in Borteomib-resistant cell models $[56,57]$. Due to the broad nature of inhibition and the relatively common acquisition of resistance for PIs, targeting upstream UPS regulators such as the E1-E2-E3 enzyme cascade or DUB enzymes is an attractive alternative [58]. 
Table 1. Small-molecule inhibitors of the proteasome, E1 activating enzymes, and E2 conjugating enzymes.

\begin{tabular}{|c|c|c|c|c|c|c|}
\hline $\begin{array}{l}\text { Compound } \\
\text { Name }\end{array}$ & UPS Target & Mode of Action & $\begin{array}{c}\text { Current } \\
\text { Clinical Stage }\end{array}$ & $\begin{array}{c}\text { Cancer Models } \\
\text { Targeted in } \\
\text { Preclinical Studies }\end{array}$ & $\begin{array}{c}\text { Targeted Cancer } \\
\text { Types in Clinical } \\
\text { Trials }\end{array}$ & $\begin{array}{c}\text { Clinical } \\
\text { Trial } \\
\text { Results }\end{array}$ \\
\hline \multicolumn{7}{|c|}{ Proteasome Inhibitors } \\
\hline Bortezomib & $\begin{array}{c}\text { Proteasome } \\
(20 \mathrm{~S} \\
\text { particle })\end{array}$ & $\begin{array}{l}\text { Reversibly binds } \\
\text { active sites of } 20 \mathrm{~S} \\
\text { proteasome }\end{array}$ & $\begin{array}{l}\text { FDA approved } \\
\text { (Phase 4) }\end{array}$ & $\begin{array}{l}\text { MM, lymphocytic } \\
\text { leukemia cells, oral } \\
\text { squamous } \\
\text { carcinoma cells, } \\
\text { and more [32] }\end{array}$ & $\begin{array}{c}\text { MM, AML, } \\
\text { colorectal cancer, } \\
\text { head and neck } \\
\text { cancer, mantle cell } \\
\text { lymphoma, and } \\
\text { more }\end{array}$ & [59-61] \\
\hline Carfilzomib & $\begin{array}{c}\text { Proteasome } \\
(20 \mathrm{~S} \\
\text { particle })\end{array}$ & $\begin{array}{c}\text { Irreversibly binds } \\
\text { active sites of } 20 S \\
\text { proteasome }\end{array}$ & $\begin{array}{l}\text { FDA approved } \\
\text { (Phase } 4)\end{array}$ & $\begin{array}{l}\text { Hematologic } \\
\text { tumors [37] }\end{array}$ & $\begin{array}{l}\text { MM, lymphoma, } \\
\text { thyroid cancer, } \\
\text { lung cancer, kidney } \\
\text { cancer, and more }\end{array}$ & {$[36,62-64]$} \\
\hline Oprozomib & $\begin{array}{c}\text { Proteasome } \\
\text { (20S } \\
\text { particle })\end{array}$ & $\begin{array}{l}\text { Irreversibly binds } \\
\text { active sites of } 20 S \\
\text { proteasome }\end{array}$ & Phase $1 b / 2$ & MM [65] & $\begin{array}{l}\text { Solid tumors, } \\
\text { hepatocellular } \\
\text { carcinoma, MM, } \\
\text { waldenstrom } \\
\text { macroglobuline- } \\
\text { mia, and } \\
\text { more }\end{array}$ & {$[66]$} \\
\hline Ixazomib & $\begin{array}{c}\text { Proteasome } \\
(20 \mathrm{~S} \\
\text { particle })\end{array}$ & $\begin{array}{c}\text { Inhibits } \\
\text { chymotrypsin- } \\
\text { like activity of } \\
\text { 20S proteasome }\end{array}$ & $\begin{array}{l}\text { FDA approved } \\
\text { (Phase 4) }\end{array}$ & $\begin{array}{c}\text { Solid and } \\
\text { hematologic } \\
\text { tumors [67], MM } \\
\text { [68], B-cell, plasma } \\
\text { cell malignancies } \\
\text { [69] }\end{array}$ & $\begin{array}{c}\text { MM, re- } \\
\text { lapsed/refractory } \\
\text { MM, AML, } \\
\text { Hodgkin and T-cell } \\
\text { lymphoma, breast } \\
\text { cancer, and more }\end{array}$ & {$[70,71]$} \\
\hline $\begin{array}{l}\text { IU1, IU1-47, } \\
\text { 1B10, IU1-248 }\end{array}$ & $\begin{array}{c}\text { Proteasome } \\
(19 S \\
\text { particle })\end{array}$ & $\begin{array}{l}\text { Inhibit USP14 } \\
\text { (proteasome- } \\
\text { associated DUB) } \\
\text { via steric site }\end{array}$ & Preclinical & $\mathrm{N} / \mathrm{A}$ & $\mathrm{N} / \mathrm{A}$ & $\mathrm{N} / \mathrm{A}$ \\
\hline b-AP15 & $\begin{array}{c}\text { Proteasome } \\
\text { (19S } \\
\text { particle) }\end{array}$ & $\begin{array}{l}\text { Targets UCHL5 } \\
\text { and USP14 } \\
\text { (proteasome- } \\
\text { associated } \\
\text { DUBs) }\end{array}$ & Preclinical & $\begin{array}{c}\text { Solid tumors, MM } \\
{[40,72-74]}\end{array}$ & $\mathrm{N} / \mathrm{A}$ & $\mathrm{N} / \mathrm{A}$ \\
\hline VLX1570 & $\begin{array}{c}\text { Proteasome } \\
\text { (19S } \\
\text { particle) }\end{array}$ & $\begin{array}{c}\text { Analog of } \\
\text { b-AP15, also } \\
\text { targets UCHL5 } \\
\text { and USP14 }\end{array}$ & $\begin{array}{c}\text { Preclinical } \\
\text { (Phase } 1 / 2 \\
\text { terminated) }\end{array}$ & MM [42] & MM & $\mathrm{N} / \mathrm{A}$ \\
\hline WP1130 & $\begin{array}{c}\text { Proteasome } \\
\text { (19S } \\
\text { particle })\end{array}$ & $\begin{array}{c}\text { Inhibits USP9X, } \\
\text { UCHL, and } \\
\text { USP14 }\end{array}$ & Preclinical & $\begin{array}{c}\text { Chronic } \\
\text { myelogenous } \\
\text { leukemia }(\mathrm{CML}), \\
\text { melanoma, } \\
\text { glioblastoma, } \\
\text { myeproliferative } \\
\text { disorders [44,75,76], } \\
\text { MCL [77], AML } \\
\text { [78] }\end{array}$ & $\mathrm{N} / \mathrm{A}$ & $\mathrm{N} / \mathrm{A}$ \\
\hline RA-9 & $\begin{array}{c}\text { Proteasome } \\
\text { (19S } \\
\text { particle) }\end{array}$ & $\begin{array}{l}\text { Inhibits } \\
\text { proteasome- } \\
\text { associated } \\
\text { DUBs }\end{array}$ & Preclinical & Ovarian cancer [43] & $\mathrm{N} / \mathrm{A}$ & $\mathrm{N} / \mathrm{A}$ \\
\hline
\end{tabular}


Table 1. Cont.

\begin{tabular}{|c|c|c|c|c|c|c|}
\hline $\begin{array}{l}\text { Compound } \\
\text { Name }\end{array}$ & UPS Target & Mode of Action & $\begin{array}{c}\text { Current } \\
\text { Clinical Stage }\end{array}$ & $\begin{array}{c}\text { Cancer Models } \\
\text { Targeted in } \\
\text { Preclinical Studies }\end{array}$ & $\begin{array}{c}\text { Targeted Cancer } \\
\text { Types in Clinical } \\
\text { Trials }\end{array}$ & $\begin{array}{c}\text { Clinical } \\
\text { Trial } \\
\text { Results }\end{array}$ \\
\hline RA190 & $\begin{array}{c}\text { Proteasome } \\
(19 S \\
\text { particle })\end{array}$ & $\begin{array}{c}\text { Inhibits RNP13 } \\
\text { and inactivates } \\
\text { Uch37 }\end{array}$ & Preclinical & $\begin{array}{l}\text { MM, ovarian } \\
\text { cancer [45] }\end{array}$ & $\mathrm{N} / \mathrm{A}$ & $\mathrm{N} / \mathrm{A}$ \\
\hline $\begin{array}{l}\text { Capzimin, } \\
\text { 8TQ }\end{array}$ & $\begin{array}{c}\text { Proteasome } \\
(19 S \\
\text { particle })\end{array}$ & $\begin{array}{c}\text { Specifically target } \\
\text { RPN11 }\end{array}$ & Preclinical & $\begin{array}{c}\text { Leukemia, NSCLC, } \\
\text { breast cancer [79] }\end{array}$ & $\mathrm{N} / \mathrm{A}$ & $\mathrm{N} / \mathrm{A}$ \\
\hline $\begin{array}{l}\text { Thiolutin, } \\
\text { SOP11 }\end{array}$ & $\begin{array}{c}\text { Proteasome } \\
(19 S \\
\text { particle })\end{array}$ & $\begin{array}{l}\text { Targets RPN11 } \\
\text { and other } \\
\text { JAMM-family } \\
\text { DUBs }\end{array}$ & Preclinical & $\begin{array}{c}\text { Colon cancer, } \\
\text { bortezomib- } \\
\text { resistant RPE cells } \\
{[80]}\end{array}$ & $\mathrm{N} / \mathrm{A}$ & $\mathrm{N} / \mathrm{A}$ \\
\hline \multicolumn{7}{|c|}{ E1 inhibitors } \\
\hline PYR-41 & UBA1 & $\begin{array}{l}\text { Irreversibly binds } \\
\text { active site } \\
\text { cysteine of UBA1 }\end{array}$ & Preclinical & $\mathrm{N} / \mathrm{A}$ & $\mathrm{N} / \mathrm{A}$ & $\mathrm{N} / \mathrm{A}$ \\
\hline $\begin{array}{l}\text { MLN4942 } \\
\text { (Pevonedis- } \\
\text { tat) }\end{array}$ & NAE & $\begin{array}{l}\text { Binds NEDD8, } \\
\text { prevents CRL } \\
\text { neddylation to } \\
\text { inhibit activity }\end{array}$ & Phase 3 & $\begin{array}{l}\text { Colon cancer, lung } \\
\text { cancer, myeloma, } \\
\text { lymphoma } \\
\text { [81-83] }\end{array}$ & $\begin{array}{c}\text { AML, MM, } \\
\text { lymphoma, } \\
\text { melanoma, lung } \\
\text { cancer, PCM, and } \\
\text { more }\end{array}$ & [84-87] \\
\hline \multicolumn{7}{|c|}{ E2 inhibitors } \\
\hline CC0651 & hCdc34 & $\begin{array}{l}\text { Binds allosteric } \\
\text { pocket causing } \\
\text { structural } \\
\text { displacement }\end{array}$ & Preclinical & $\begin{array}{l}\text { Prostate and } \\
\text { colorectal cancer } \\
\text { cell lines [88] }\end{array}$ & $\mathrm{N} / \mathrm{A}$ & $\mathrm{N} / \mathrm{A}$ \\
\hline NSC697923 & Ubc-Uev1A & $\begin{array}{c}\text { Impedes } \\
\text { formation of } \\
\text { Ubc13 and Ub } \\
\text { thioester } \\
\text { conjugate }\end{array}$ & Preclinical & $\begin{array}{l}\text { Diffuse large B-cell } \\
\text { lymphoma } \\
\text { (DLBCL) [89] }\end{array}$ & $\mathrm{N} / \mathrm{A}$ & $\mathrm{N} / \mathrm{A}$ \\
\hline
\end{tabular}

\subsection{Targeting E1 and E2 Enzymes}

There are only two inhibitors targeting the E1 activating step in the E1-E2-E3 cascade: PYR-41 for the inhibition of UBA1 [90,91] and MLN4942 (i.e., Pevonedistat), a smallmolecule inhibitor of NEDD8-activating enzyme (NAE) [81]. NEDD8 is a Ub-like protein whose conjugation to cullin-RING E3 ligases (CRLs) is imperative for the degradation of CRL substrates, many of which are relevant in various cancers [92]. The E1 enzyme NAE activates NEDD8, and Pevonedistat covalently binds NEDD8, forming a complex that prevents NAE's conjugation of NEDD8 to CRL and causing accumulation of CRL substrates $[81,93]$. Pevonedistat is being investigated in several clinical trials, including two Phase 3 trials currently recruiting for treatment of patients with acute myelogenous leukemia (AML) (Table 1).

E2 enzymes confers significantly more potential targets for small-molecule inhibitors compared to the E1s. However, since E2 can associate with multiple E3s, less attention has been given to the E2s as drug targets compared to the E3s due to specificity concerns [17]. Nevertheless, CC0651 and NSC697923 (Table 1) are small molecules that inhibit human E2 enzymes and have shown some success at reducing cancer cell growth [88,89]. The vast number of available E3 and DUB enzymes and their characteristically substrate-specific mechanisms make them ideal downstream UPS targets for inhibition by cancer therapeutics, as described below. 


\subsection{Targeting E3 Ligases}

As mentioned above, the E3 ligases can be divided into three main classes with different structures and catalytic mechanisms. The RING E3 ligases are defined by the RING domain that coordinates two Zinc ions at the structural level [94]. Mechanistically, the RING E3 ligases act as a scaffold to bring the E2-Ub complex and the substrate together and facilitate direct $\mathrm{Ub}$ transfer from E2 to substrate [95]. Within the RING E3 class, there is the CRL superfamily, which consists of a cullin protein (CUL) acting as a scaffold to interact with an adaptor and substrate receptor [96]. The CRLs are well represented by the Skp1Cul1-F-box protein (SCF) E3s, in which one of the $\sim 70$ human F-box proteins can perform substrate recognition [97]. In contrast to the RING E3s, the HECT E3s performs a more catalytic role in ubiquitination by forming a thioester bond with $\mathrm{Ub}$ via a cysteine residue in the HECT domain before Ub transfer [98]. The 28 known human HECTs are divided into three families based on their N-term structure: NEDD4, HERC, and "other" [99]. The third major class of E3 ligases, the RBRs, consists of around 13 members in humans, defined by two RING domains separated by a cysteine-rich in-between-ring (IBR) domain [95]. RBR E3s employ a hybrid mechanism of the RING and HECT E3s, and well-known RBR members include PARKIN, HOIP, and HOIL-1L [95,100].

Due to the high substrate selectivity by which E3s mediate protein degradation, their inhibition poses little risk of off-target effects [10]. However, it is important to consider the context of the target tissue/tumor type, as E3 ligases can have tumor suppressing or promoting effects at the same time [17]. Inhibition of cancer promoting substrates without affecting normal cells is desired, but the complicated regulatory systems at play can pose challenges. To this end, many small-molecule inhibitors have been identified for human E3 ligases, with varying levels of success seen in vitro, in cells, in animal models, and in clinical trials (Table 2).

Table 2. Small-molecule inhibitors of the E3 ubiquitin ligases.

\begin{tabular}{|c|c|c|c|c|c|c|}
\hline $\begin{array}{l}\text { Compound } \\
\text { Name }\end{array}$ & $\begin{array}{l}\text { UPS } \\
\text { Target }\end{array}$ & Mode of Action & $\begin{array}{c}\text { Current } \\
\text { Clinical Stage }\end{array}$ & $\begin{array}{l}\text { Cancer Models } \\
\text { Targeted in } \\
\text { Preclinical Studies }\end{array}$ & $\begin{array}{c}\text { Targeted Cancer } \\
\text { Types in Clinical } \\
\text { Trials }\end{array}$ & $\begin{array}{c}\text { Published } \\
\text { Clinical Trial } \\
\text { Results }\end{array}$ \\
\hline \multicolumn{7}{|c|}{ MDM2 inhibitors } \\
\hline Nutlin-3 & MDM2 & $\begin{array}{c}\text { Competitive } \\
\text { inhibitor of p53 } \\
\text { binding site on } \\
\text { MDM2 }\end{array}$ & Preclinical & $\begin{array}{c}\text { AML [101], } \\
\text { hematologic } \\
\text { malignancies } \\
\text { [102-105], breast } \\
\text { cancers [106,107], } \\
\text { glioblastoma [108] }\end{array}$ & $\mathrm{N} / \mathrm{A}$ & $\mathrm{N} / \mathrm{A}$ \\
\hline $\begin{array}{c}\text { RG7112 } \\
(\text { RO5045337) }\end{array}$ & MDM2 & $\begin{array}{c}\text { Nutlin derivative, } \\
\text { inhibits } \\
\text { MDM2-p53 } \\
\text { binding site }\end{array}$ & Phase 1 & $\begin{array}{c}\text { Cancer cell lines } \\
\text { expressing } \\
\text { wild-type p53 [109] }\end{array}$ & $\begin{array}{c}\text { Leukemia, } \\
\text { hematologic } \\
\text { neoplasms, } \\
\text { liposarcoma, } \\
\text { advanced solid } \\
\text { tumors, } \\
\text { myeloproliferative } \\
\text { neoplasms }\end{array}$ & [110-112] \\
\hline $\begin{array}{l}\text { RG7388 } \\
\text { (RO5503781, } \\
\text { Idasanutlin) }\end{array}$ & MDM2 & $\begin{array}{c}\text { Nutlin derivative, } \\
\text { inhibits } \\
\text { MDM2-p53 } \\
\text { binding site }\end{array}$ & $\begin{array}{c}\text { Phase } 2 \text { (Phase } \\
3 \text { terminated) }\end{array}$ & $\begin{array}{l}\text { Cancer cell lines } \\
\text { expressing } \\
\text { wild-type p53, } \\
\text { osteosarcoma } \\
\text { xenografts [113] }\end{array}$ & $\begin{array}{l}\text { AML, ALL, solid } \\
\text { tumors, } \\
\text { neuroblastoma, } \\
\text { plasma cell } \\
\text { myeloma, breast } \\
\text { cancer, PV and ET, } \\
\text { and more }\end{array}$ & [114-116] \\
\hline
\end{tabular}


Table 2. Cont.

\begin{tabular}{|c|c|c|c|c|c|c|}
\hline $\begin{array}{l}\text { Compound } \\
\text { Name }\end{array}$ & $\begin{array}{l}\text { UPS } \\
\text { Target }\end{array}$ & Mode of Action & $\begin{array}{c}\text { Current } \\
\text { Clinical Stage }\end{array}$ & $\begin{array}{c}\text { Cancer Models } \\
\text { Targeted in } \\
\text { Preclinical Studies }\end{array}$ & $\begin{array}{c}\text { Targeted Cancer } \\
\text { Types in Clinical } \\
\text { Trials }\end{array}$ & $\begin{array}{c}\text { Published } \\
\text { Clinical Trial } \\
\text { Results }\end{array}$ \\
\hline $\begin{array}{c}\text { MI-77301 } \\
\text { (SAR405838) }\end{array}$ & MDM2 & $\begin{array}{l}\text { Selectively binds } \\
\text { MDM2-p53 } \\
\text { binding site, } \\
\text { improved affinity } \\
\text { via MDM2 } \\
\text { N-term refolding }\end{array}$ & Phase 1 & $\begin{array}{c}\text { Leukemia, } \\
\text { osteosarcoma, } \\
\text { prostate and colon } \\
\text { cancer cell lines } \\
\text { [117] }\end{array}$ & $\begin{array}{c}\text { Malignant } \\
\text { neoplasms, } \\
\text { advanced solid } \\
\text { tumors, lymphoma }\end{array}$ & {$[118,119]$} \\
\hline $\begin{array}{c}\text { MK-8242 } \\
\text { (SCH-900242) }\end{array}$ & MDM2 & $\begin{array}{l}\text { Oral MDM2-p53 } \\
\text { inhibitor }\end{array}$ & Phase 1 & $\mathrm{~N} / \mathrm{A}$ & $\begin{array}{l}\text { AML, advanced } \\
\text { solid tumors }\end{array}$ & {$[120,121]$} \\
\hline AMG 232 & MDM2 & $\begin{array}{c}\text { Inhibits } \\
\text { MDM2-p53 } \\
\text { interaction with } \\
\text { improved } \\
\text { potency due to } \\
\text { hydrophobic } \\
\text { interactions with } \\
\text { MDM2 "glycine } \\
\text { shelf" }\end{array}$ & Phase 1 & $\begin{array}{l}\text { Various tumor cell } \\
\text { lines and } \\
\text { xenografts } \\
{[122-124]}\end{array}$ & $\begin{array}{l}\text { AML, advanced } \\
\text { solid tumors, } \\
\text { glioblastoma, } \\
\text { gliosarcoma, } \\
\text { metastatic } \\
\text { melanoma, MM, } \\
\text { and more }\end{array}$ & {$[125,126]$} \\
\hline $\begin{array}{c}\text { Ds3032b } \\
\text { (Milademetan) }\end{array}$ & MDM2 & $\begin{array}{l}\text { Oral MDM2-p53 } \\
\text { inhibitor }\end{array}$ & Phase 2 & $\begin{array}{l}\text { Neuroblastoma } \\
\text { [127], BCL [10] }\end{array}$ & $\begin{array}{l}\text { Myeloma, AML, re- } \\
\text { current/refractory } \\
\text { myeloid leukemia, } \\
\text { advanced solid } \\
\text { tumors, } \\
\text { lymphomas }\end{array}$ & {$[128,129]$} \\
\hline $\begin{array}{l}\text { HDM } 201 \\
\text { (Siremadlin) }\end{array}$ & MDM2 & $\begin{array}{l}\text { Binds to MDM2, } \\
\text { inhibits } \\
\text { interaction with } \\
\text { p53 }\end{array}$ & Phase 2 & $\begin{array}{l}\text { Wild-type-p53 } \\
\text { cancer cell lines } \\
\text { [130] }\end{array}$ & $\begin{array}{l}\text { AML, colorectal } \\
\text { cancer, liposarcoma, } \\
\text { malignant solid } \\
\text { tumors, and more }\end{array}$ & {$[131,132]$} \\
\hline APG-115 & MDM2 & $\begin{array}{l}\text { Oral MDM2-p53 } \\
\text { inhibitor }\end{array}$ & Phase 2 & $\begin{array}{c}\text { Osteosarcoma } \\
\text { xenografts [133] }\end{array}$ & $\begin{array}{c}\text { AML, } \\
\text { T-prolymphocytic } \\
\text { leukemia, } \\
\text { liposarcoma, } \\
\text { advanced solid } \\
\text { tumors, melanoma, } \\
\text { salivary gland } \\
\text { cancer }\end{array}$ & {$[134,135]$} \\
\hline CGM097 & MDM2 & $\begin{array}{l}\text { MDM2-p53 } \\
\text { inhibitor }\end{array}$ & Phase 1 & $\begin{array}{c}\text { Colorectal cancer, } \\
\text { osteosarcoma cells } \\
\text { [136] }\end{array}$ & $\begin{array}{l}\text { Solid tumors with } \\
\text { wild-type p53 }\end{array}$ & $\mathrm{N} / \mathrm{A}$ \\
\hline $\begin{array}{l}\text { PRIMA1, } \\
\text { APR-246 }\end{array}$ & MDM2 & $\begin{array}{l}\text { Binds core } \\
\text { domain of p53, } \\
\text { preventing } \\
\text { MDM2 } \\
\text { association }\end{array}$ & Phase 3 & $\begin{array}{c}\text { Osteosarcoma, } \\
\text { NSCLC, } \\
\text { adenocarcinoma } \\
\text { cell lines and } \\
\text { xenografts } \\
{[137,138], \text { myeloma }} \\
\text { [139] }\end{array}$ & $\begin{array}{c}\text { AML, myeloid } \\
\text { malignancies, } \\
\text { NSCLC, gastric } \\
\text { cancer, esophageal } \\
\text { carcinoma, } \\
\text { non-Hodgkin's } \\
\text { lymphoma, CLL, } \\
\text { MCL, hematologic } \\
\text { neoplasms, and } \\
\text { more }\end{array}$ & [140] \\
\hline MI-63 & MDM2 & $\begin{array}{l}\text { Binds MDM2, } \\
\text { preventing p53 } \\
\text { association }\end{array}$ & Preclinical & $\begin{array}{c}\text { Prostate cancer } \\
\text { cells with wt-p53 } \\
\text { [141] }\end{array}$ & $\mathrm{N} / \mathrm{A}$ & $\mathrm{N} / \mathrm{A}$ \\
\hline
\end{tabular}


Table 2. Cont.

\begin{tabular}{|c|c|c|c|c|c|c|}
\hline $\begin{array}{l}\text { Compound } \\
\text { Name }\end{array}$ & $\begin{array}{l}\text { UPS } \\
\text { Target }\end{array}$ & Mode of Action & $\begin{array}{c}\text { Current } \\
\text { Clinical Stage }\end{array}$ & $\begin{array}{l}\text { Cancer Models } \\
\text { Targeted in } \\
\text { Preclinical Studies }\end{array}$ & $\begin{array}{c}\text { Targeted Cancer } \\
\text { Types in Clinical } \\
\text { Trials }\end{array}$ & $\begin{array}{c}\text { Published } \\
\text { Clinical Trial } \\
\text { Results }\end{array}$ \\
\hline MI-219 & MDM2 & $\begin{array}{l}\text { Binds MDM2, } \\
\text { preventing p53 } \\
\text { association; can } \\
\text { also induce } \\
\text { degradation of } \\
\text { MDMX. }\end{array}$ & Preclinical & $\begin{array}{l}\text { Various solid } \\
\text { cancer cell lines, } \\
\text { osteosarcoma } \\
\text { xenografts [142] }\end{array}$ & $\mathrm{N} / \mathrm{A}$ & $\mathrm{N} / \mathrm{A}$ \\
\hline Sempervirine & MDM2 & $\begin{array}{l}\text { MDM2-p53 } \\
\text { inhibitor }\end{array}$ & Preclinical & $\begin{array}{l}\text { Wt-p53 mouse } \\
\text { embryonic } \\
\text { fibroblast cell } \\
\text { model [143] }\end{array}$ & $\mathrm{N} / \mathrm{A}$ & $\mathrm{N} / \mathrm{A}$ \\
\hline RITA & MDM2 & $\begin{array}{l}\text { Binds wt-p53, } \\
\text { preventing } \\
\text { association with } \\
\text { MDM2 }\end{array}$ & Preclinical & $\begin{array}{c}\text { Fibrosarcoma and } \\
\text { colon cancer cell } \\
\text { lines and wt-p53 } \\
\text { tumor xenografts } \\
{[144]}\end{array}$ & $\mathrm{N} / \mathrm{A}$ & $\mathrm{N} / \mathrm{A}$ \\
\hline Syl-155 & MDM2 & $\begin{array}{l}\text { Competitively } \\
\text { inhibits } \\
\text { MDM2-p53 } \\
\text { binding }\end{array}$ & Preclinical & $\begin{array}{c}\text { Wt-p53 } \\
\text { fibrosarcoma cell } \\
\text { line [145] }\end{array}$ & $\mathrm{N} / \mathrm{A}$ & $\mathrm{N} / \mathrm{A}$ \\
\hline HLI373 & MDM2 & $\begin{array}{l}\text { Competitively } \\
\text { inhibits } \\
\text { MDM2-p53 } \\
\text { binding }\end{array}$ & Preclinical & $\begin{array}{l}\text { Colon carcinoma } \\
\text { cell line, wt-p53 } \\
\text { transformed MEF } \\
\text { cell model [146] }\end{array}$ & $\mathrm{N} / \mathrm{A}$ & $\mathrm{N} / \mathrm{A}$ \\
\hline MEL24 & MDMX/N & $\begin{array}{l}\text { Inhibits E3 ligase } \\
\text { DM2 activity of } \\
\text { MDM2-MDMX } \\
\text { complex }\end{array}$ & Preclinical & $\begin{array}{c}\text { Various wt-p53 } \\
\text { cancer cell lines } \\
{[147]}\end{array}$ & $\mathrm{N} / \mathrm{A}$ & $\mathrm{N} / \mathrm{A}$ \\
\hline $\begin{array}{l}\text { NSC207895 } \\
(\text { XI-006) }\end{array}$ & MDMX & $\begin{array}{c}\text { Represses MDMX } \\
\text { transcription, } \\
\text { activates p53 } \\
\text { pathway }\end{array}$ & Preclinical & $\begin{array}{l}\text { Various solid tumor } \\
\text { cell lines [148] }\end{array}$ & $\mathrm{N} / \mathrm{A}$ & $\mathrm{N} / \mathrm{A}$ \\
\hline \multicolumn{7}{|c|}{ CRL/SCF RING E3 inhibitors } \\
\hline Oridonin & FBW7 & $\begin{array}{c}\text { Promotes } \\
\text { proteasomal } \\
\text { degradation of } \\
\text { c-Myc via FBW7 } \\
\text { agonism }\end{array}$ & Preclinical & $\begin{array}{l}\text { Leukemia and } \\
\text { lymphoma cell } \\
\text { lines [149] }\end{array}$ & $\mathrm{N} / \mathrm{A}$ & $\mathrm{N} / \mathrm{A}$ \\
\hline SCF-I2 & FBW7 & $\begin{array}{l}\text { Blocks substrate- } \\
\text { binding pocket, } \\
\text { inhibits Cdc4, } \\
\text { prevents } \\
\text { substrate } \\
\text { recognition }\end{array}$ & Preclinical & $\begin{array}{c}\text { Colon and prostate } \\
\text { cancer cell lines } \\
\text { [150] }\end{array}$ & $\mathrm{N} / \mathrm{A}$ & $\mathrm{N} / \mathrm{A}$ \\
\hline SMER3 & Met30 & $\begin{array}{l}\text { Directly binds } \\
\text { Met30, } \\
\text { preventing } \\
\text { association with } \\
\text { SCF complex }\end{array}$ & Preclinical & $\mathrm{N} / \mathrm{A}$ & $\mathrm{N} / \mathrm{A}$ & $\mathrm{N} / \mathrm{A}$ \\
\hline
\end{tabular}


Table 2. Cont.

\begin{tabular}{|c|c|c|c|c|c|c|}
\hline $\begin{array}{l}\text { Compound } \\
\text { Name }\end{array}$ & $\begin{array}{l}\text { UPS } \\
\text { Target }\end{array}$ & Mode of Action & $\begin{array}{c}\text { Current } \\
\text { Clinical Stage }\end{array}$ & $\begin{array}{c}\text { Cancer Models } \\
\text { Targeted in } \\
\text { Preclinical Studies }\end{array}$ & $\begin{array}{c}\text { Targeted Cancer } \\
\text { Types in Clinical } \\
\text { Trials }\end{array}$ & $\begin{array}{c}\text { Published } \\
\text { Clinical Trial } \\
\text { Results }\end{array}$ \\
\hline Compound A & SKP2 & $\begin{array}{c}\text { Prevents } \\
\text { association of } \\
\text { SKP2 with SCF } \\
\text { complex, results } \\
\text { in accumulation } \\
\text { of p27 }\end{array}$ & Preclinical & $\begin{array}{c}\text { MM cell lines, } \\
\text { primary } \\
\text { hematological } \\
\text { malignancy cells } \\
\text { [151] }\end{array}$ & $\mathrm{N} / \mathrm{A}$ & $\mathrm{N} / \mathrm{A}$ \\
\hline SMIP004 & SKP2 & $\begin{array}{c}\text { Downregulates } \\
\text { SKP2, stabilizes } \\
\text { p27 }\end{array}$ & Preclinical & $\begin{array}{c}\text { Prostate } \\
\text { adenocarcinoma } \\
\text { cell lines [152] }\end{array}$ & $\mathrm{N} / \mathrm{A}$ & $\mathrm{N} / \mathrm{A}$ \\
\hline $\mathrm{C} 1, \mathrm{C} 2, \mathrm{C} 3$ & SKP2 & $\begin{array}{l}\text { Sterically inhibits } \\
\text { SKP2-Cks1-p27 } \\
\text { interface }\end{array}$ & Preclinical & $\begin{array}{c}\text { Metastatic } \\
\text { melanoma cell } \\
\text { lines, breast cancer } \\
\text { cells }[153]\end{array}$ & $\mathrm{N} / \mathrm{A}$ & $\mathrm{N} / \mathrm{A}$ \\
\hline $\begin{array}{l}\text { SZL-P1-41 } \\
\text { (Compound } \\
\text { \#25) }\end{array}$ & SKP2 & $\begin{array}{l}\text { Directly binds } \\
\text { SKP2 to inhibit } \\
\text { E3 activity }\end{array}$ & Preclinical & $\begin{array}{c}\text { Prostate, lung, liver, } \\
\text { and osteosarcoma } \\
\text { tumor cell lines } \\
{[154]}\end{array}$ & $\mathrm{N} / \mathrm{A}$ & $\mathrm{N} / \mathrm{A}$ \\
\hline $\begin{array}{c}\text { Longikaurin } \\
\text { A }\end{array}$ & SKP2 & $\begin{array}{l}\text { Downregulates } \\
\text { SKP2 expression }\end{array}$ & Preclinical & $\begin{array}{l}\text { Hepatocellular } \\
\text { carcinoma [155] }\end{array}$ & $\mathrm{N} / \mathrm{A}$ & $\mathrm{N} / \mathrm{A}$ \\
\hline Curcumin & SKP2 & $\begin{array}{l}\text { Downregulates } \\
\text { SKP2 }\end{array}$ & Phase 3 & $\begin{array}{c}\text { Breast cancers } \\
\text { [156], pancreatic } \\
\text { cancer [157], } \\
\text { glioma cells [158] }\end{array}$ & $\begin{array}{c}\text { Prostate cancer, } \\
\text { pancreatic cancer, } \\
\text { colorectal cancer, } \\
\text { MM, gastric cancer, } \\
\text { breast cancer, } \\
\text { leukemias and } \\
\text { lymphomas, and } \\
\text { more }\end{array}$ & {$[159,160]$} \\
\hline Erioflorin & $\beta-\operatorname{TrCP} 1$ & $\begin{array}{l}\text { Interferes with } \beta \text { - } \\
\text { TrCP1 to stabilize } \\
\text { tumor suppressor } \\
\text { Pdcd } 4\end{array}$ & Preclinical & $\begin{array}{c}\text { Kidney, breast, } \\
\text { ovarian, and colon } \\
\text { cancer cell lines } \\
{[161]}\end{array}$ & $\mathrm{N} / \mathrm{A}$ & $\mathrm{N} / \mathrm{A}$ \\
\hline GS143 & $\beta-\operatorname{TrCP} 1$ & $\begin{array}{l}\text { Inhibits } \beta \text {-TrCP1 } \\
\text { ubiquitination of } \\
\text { IkB, suppresses } \\
\text { NF-kB signaling }\end{array}$ & Preclinical & $\mathrm{N} / \mathrm{A}$ & $\mathrm{N} / \mathrm{A}$ & $\mathrm{N} / \mathrm{A}$ \\
\hline \multicolumn{7}{|c|}{ Other RING E3 inhibitors } \\
\hline CCW 28-3 & RNF4 & $\begin{array}{l}\text { Binds RNF4 to } \\
\text { facilitate } \\
\text { degradation of } \\
\text { BRD4 }\end{array}$ & Preclinical & $\begin{array}{c}\text { Breast cancer cells } \\
\text { [162] }\end{array}$ & $\mathrm{N} / \mathrm{A}$ & $\mathrm{N} / \mathrm{A}$ \\
\hline GDC-0152 & IAPs & $\begin{array}{l}\text { SMAC mimetic, } \\
\text { induces IAP } \\
\text { degradation, } \\
\text { activates caspases }\end{array}$ & $\begin{array}{l}\text { Preclinical } \\
\text { (Phase } 1 \\
\text { terminated) }\end{array}$ & $\begin{array}{c}\text { Breast cancer cell } \\
\text { lines and } \\
\text { xenografts [163] }\end{array}$ & Solid cancers & $\mathrm{N} / \mathrm{A}$ \\
\hline
\end{tabular}


Table 2. Cont.

\begin{tabular}{|c|c|c|c|c|c|c|}
\hline $\begin{array}{l}\text { Compound } \\
\text { Name }\end{array}$ & $\begin{array}{l}\text { UPS } \\
\text { Target }\end{array}$ & Mode of Action & $\begin{array}{c}\text { Current } \\
\text { Clinical Stage }\end{array}$ & $\begin{array}{c}\text { Cancer Models } \\
\text { Targeted in } \\
\text { Preclinical Studies }\end{array}$ & $\begin{array}{c}\text { Targeted Cancer } \\
\text { Types in Clinical } \\
\text { Trials }\end{array}$ & $\begin{array}{c}\text { Published } \\
\text { Clinical Trial } \\
\text { Results }\end{array}$ \\
\hline LCL161 & IAPs & $\begin{array}{l}\text { SMAC mimetic, } \\
\text { induces } \\
\text { degradation of } \\
\text { cIAP-1 }\end{array}$ & Phase 2 & $\begin{array}{l}\text { Various solid tumor } \\
\text { cell lines [164], } \\
\text { hepatocellular } \\
\text { carcinoma [165], } \\
\text { osteosarcoma [166], } \\
\text { and more }\end{array}$ & $\begin{array}{l}\text { Neoplasms, plasma } \\
\text { cell myeloma, } \\
\text { metastatic } \\
\text { pancreatic cancer, } \\
\text { myelofibrosis, } \\
\text { small cell lung } \\
\text { cancer, ovarian } \\
\text { cancer, breast } \\
\text { cancer, MM, and } \\
\text { more }\end{array}$ & [167] \\
\hline $\begin{array}{c}\text { AT-406 } \\
(\text { DEBIO1143, } \\
\text { SM-406) }\end{array}$ & IAPs & $\begin{array}{l}\text { SMAC mimetic; } \\
\text { binds XIAP, } \\
\text { cIAP-1, and } \\
\text { cIAP-2; and } \\
\text { activates caspases }\end{array}$ & Phase 3 & $\begin{array}{l}\text { Breast cancer [168], } \\
\text { colorectal cancer } \\
\text { [169], ovarian } \\
\text { cancer [170] }\end{array}$ & $\begin{array}{l}\text { Lymphoma, solid } \\
\text { tumors, AML, } \\
\text { NSCLC, squamous } \\
\text { cell carcinoma of } \\
\text { head and neck, } \\
\text { MM, and more }\end{array}$ & {$[171,172]$} \\
\hline $\begin{array}{c}\text { AEG 35,156 } \\
(\text { GEM640), } \\
\text { AEG 40826 }\end{array}$ & XIAP & $\begin{array}{c}\text { Antisense } \\
\text { oligonucleotides } \\
\text { targeting XIAP } \\
\text { mRNA to lower } \\
\text { apoptotic } \\
\text { threshold of } \\
\text { cancer cells }\end{array}$ & Phase 2 & $\begin{array}{l}\text { Various cancer cell } \\
\text { lines, xenograft } \\
\text { models of colon, } \\
\text { breast and } \\
\text { osteosarcoma } \\
\text { tumors [173] }\end{array}$ & $\begin{array}{c}\text { Advanced solid } \\
\text { tumors, leukemia, } \\
\text { mammary } \\
\text { carcinoma, } \\
\text { pancreatic } \\
\text { carcinoma, BCL, } \\
\text { NSCLC, } \\
\text { hepatocellular } \\
\text { carcinoma, and } \\
\text { more }\end{array}$ & [174] \\
\hline TL 32711 & IAPs & $\begin{array}{l}\text { SMAC mimetic, } \\
\text { induces } \\
\text { degradation of } \\
\text { CIAP-1, and } \\
\text { caspase } \\
\text { activation }\end{array}$ & Phase 2 & $\begin{array}{l}\text { MM cell lines and } \\
\text { animal models } \\
{[175]}\end{array}$ & $\begin{array}{c}\text { Chronic } \\
\text { myelomonocytic } \\
\text { leukemia, relapsed } \\
\text { epithelial ovarian } \\
\text { cancer, } \\
\text { myelodysplastic } \\
\text { syndrome, } \\
\text { peritoneal } \\
\text { neoplasms, and } \\
\text { more }\end{array}$ & [176] \\
\hline $\begin{array}{l}\text { YM155 (sepa- } \\
\text { ntronium } \\
\text { bromide) }\end{array}$ & IAPs & $\begin{array}{l}\text { Inhibits promoter } \\
\text { of survivin gene } \\
\text { (IAP protein) }\end{array}$ & Phase 2 & $\begin{array}{c}\text { Prostate cancer cell } \\
\text { lines and } \\
\text { xenografts [177] }\end{array}$ & $\begin{array}{l}\text { Prostate cancer, } \\
\text { melanoma, } \\
\text { non-Hodgkin's } \\
\text { lymphoma, breast } \\
\text { cancer, diffuse } \\
\text { large-cell } \\
\text { lymphoma, } \\
\text { refractory B-cell } \\
\text { lymphoma, and } \\
\text { more }\end{array}$ & [178] \\
\hline C25-140 & TRAF6 & $\begin{array}{c}\text { Inhibits } \\
\text { TRAF6-Ubc13 } \\
\text { interaction } \\
\text { specifically }\end{array}$ & Preclinical & $\begin{array}{l}\text { Only studied in } \\
\text { autoimmune and } \\
\text { inflammatory } \\
\text { disease models } \\
\text { [179] }\end{array}$ & $\mathrm{N} / \mathrm{A}$ & $\mathrm{N} / \mathrm{A}$ \\
\hline
\end{tabular}


Table 2. Cont.

\begin{tabular}{|c|c|c|c|c|c|c|}
\hline $\begin{array}{l}\text { Compound } \\
\text { Name }\end{array}$ & $\begin{array}{l}\text { UPS } \\
\text { Target }\end{array}$ & Mode of Action & $\begin{array}{c}\text { Current } \\
\text { Clinical Stage }\end{array}$ & $\begin{array}{l}\text { Cancer Models } \\
\text { Targeted in } \\
\text { Preclinical Studies }\end{array}$ & $\begin{array}{c}\text { Targeted Cancer } \\
\text { Types in Clinical } \\
\text { Trials }\end{array}$ & $\begin{array}{c}\text { Published } \\
\text { Clinical Trial } \\
\text { Results }\end{array}$ \\
\hline BC-1215 & $\begin{array}{l}\text { TRAF6 } \\
\text { (via } \\
\text { FBXO3 } \\
\text { inhibi- } \\
\text { tion) }\end{array}$ & $\begin{array}{c}\text { Antagonist of } \\
\text { FBXO3, } \\
\text { destabilizes } \\
\text { TRAF6 }\end{array}$ & Preclinical & $\begin{array}{l}\text { Only studied in } \\
\text { autoimmune and } \\
\text { inflammatory } \\
\text { disease models } \\
{[180,181]}\end{array}$ & $\mathrm{N} / \mathrm{A}$ & $\mathrm{N} / \mathrm{A}$ \\
\hline
\end{tabular}

HECT E3 ligase inhibitors

\begin{tabular}{|c|c|c|c|c|c|c|}
\hline HS-152 & SMURF1 & $\begin{array}{l}\text { Reversibly blocks } \\
\text { SMURF1- } \\
\text { mediated RHOB } \\
\text { ubiquitination }\end{array}$ & Preclinical & $\begin{array}{c}\text { Inhibited } \\
\text { protrusive } \\
\text { RHOB-dependent } \\
\text { activity in cell lines } \\
\text { [182] }\end{array}$ & $\mathrm{N} / \mathrm{A}$ & $\mathrm{N} / \mathrm{A}$ \\
\hline $\begin{array}{l}\text { BI8622 and } \\
\text { BI8626 }\end{array}$ & HUWE1 & $\begin{array}{l}\text { Inhibit HUWE1 } \\
\text { to stabilize } \\
\text { assembly of } \\
\text { Myc-repressive } \\
\text { MIZ1 complex on } \\
\text { Myc-activated } \\
\text { target genes }\end{array}$ & Preclinical & $\begin{array}{l}\text { Colorectal cancer } \\
\text { [183], MM [184] }\end{array}$ & $\mathrm{N} / \mathrm{A}$ & $\mathrm{N} / \mathrm{A}$ \\
\hline Compound 12 & E6AP & $\begin{array}{c}\text { Inhibits } \\
\text { oncogenic E6-p53 } \\
\text { interaction in } \\
\text { E6-E6AP-p53 } \\
\text { complex }\end{array}$ & Preclinical & $\begin{array}{l}\text { HPV-positive } \\
\text { cervical carcinoma } \\
\text { cell lines [185] }\end{array}$ & $\mathrm{N} / \mathrm{A}$ & $\mathrm{N} / \mathrm{A}$ \\
\hline $\begin{array}{l}\text { Lutolein and } \\
\text { CAF024 }\end{array}$ & E6AP & $\begin{array}{l}\text { Bind viral E6 to } \\
\text { prevent hijacking } \\
\text { of E6AP }\end{array}$ & Preclinical & $\begin{array}{c}\text { HPV-positive } \\
\text { cervical carcinoma } \\
\text { cells [186] }\end{array}$ & $\mathrm{N} / \mathrm{A}$ & $\mathrm{N} / \mathrm{A}$ \\
\hline $\begin{array}{l}\text { Lig1, Lig2, } \\
\text { Lig3 }\end{array}$ & E6AP & $\begin{array}{l}\text { Inhibit E6-E6AP } \\
\text { interaction }\end{array}$ & Preclinical & $\mathrm{N} / \mathrm{A}$ & $\mathrm{N} / \mathrm{A}$ & $\mathrm{N} / \mathrm{A}$ \\
\hline $\begin{array}{l}\mathrm{N} \text {-acetyl } \\
\text { phenylala- } \\
\text { nine }\end{array}$ & E6AP & $\begin{array}{l}\text { Dissociates active } \\
\text { E6AP trimer }\end{array}$ & Preclinical & $\mathrm{N} / \mathrm{A}$ & $\mathrm{N} / \mathrm{A}$ & $\mathrm{N} / \mathrm{A}$ \\
\hline CM11-1 & E6AP & $\begin{array}{c}\text { E6AP inhibitor, } \\
\text { prevents polyu- } \\
\text { biquitination of } \\
\text { Prx1 in } \\
\text { E6-independent } \\
\text { and -dependent } \\
\text { manner }\end{array}$ & Preclinical & $\mathrm{N} / \mathrm{A}$ & $\mathrm{N} / \mathrm{A}$ & $\mathrm{N} / \mathrm{A}$ \\
\hline Heclin & $\begin{array}{l}\text { HECT, } \\
\text { non- } \\
\text { specific }\end{array}$ & $\begin{array}{c}\text { Induces } \\
\text { conformational } \\
\text { change in HECT } \\
\text { domain to inhibit } \\
\text { activity }\end{array}$ & Preclinical & $\mathrm{N} / \mathrm{A}$ & $\mathrm{N} / \mathrm{A}$ & $\mathrm{N} / \mathrm{A}$ \\
\hline \multicolumn{7}{|c|}{ RBR E3 ligase inhibitors } \\
\hline BAY 11-7082 & LUBAC & $\begin{array}{l}\text { Covalently binds } \\
\text { active cysteine } \\
\text { residues of E2's } \\
\text { Ubc13 and } \\
\text { UbcH7 to prevent } \\
\text { Ub conjugation }\end{array}$ & Preclinical & $\begin{array}{l}\text { B-cell lymphoma, } \\
\text { leukemia [187], } \\
\text { gastric cancer [188] }\end{array}$ & $\mathrm{N} / \mathrm{A}$ & $\mathrm{N} / \mathrm{A}$ \\
\hline
\end{tabular}


Table 2. Cont.

\begin{tabular}{|c|c|c|c|c|c|c|}
\hline $\begin{array}{l}\text { Compound } \\
\text { Name }\end{array}$ & $\begin{array}{l}\text { UPS } \\
\text { Target }\end{array}$ & Mode of Action & $\begin{array}{c}\text { Current } \\
\text { Clinical Stage }\end{array}$ & $\begin{array}{c}\text { Cancer Models } \\
\text { Targeted in } \\
\text { Preclinical Studies }\end{array}$ & $\begin{array}{c}\text { Targeted Cancer } \\
\text { Types in Clinical } \\
\text { Trials }\end{array}$ & $\begin{array}{c}\text { Published } \\
\text { Clinical Trial } \\
\text { Results }\end{array}$ \\
\hline gliotoxin & LUBAC & $\begin{array}{l}\text { Selectively binds } \\
\text { RBR domain of } \\
\text { HOIP to inhibit } \\
\text { Ub chain } \\
\text { formation }\end{array}$ & Preclinical & $\mathrm{N} / \mathrm{A}$ & $\mathrm{N} / \mathrm{A}$ & $\mathrm{N} / \mathrm{A}$ \\
\hline HOIPIN-8 & LUBAC & $\begin{array}{l}\text { Inhibits LUBAC } \\
\text { activity and } \\
\text { suppresses } \\
\text { NF-kB activation }\end{array}$ & Preclinical & $\begin{array}{c}\text { ABC-DLBCL } \\
{[189,190]}\end{array}$ & $\mathrm{N} / \mathrm{A}$ & $\mathrm{N} / \mathrm{A}$ \\
\hline Bendamustine & LUBAC & $\begin{array}{l}\text { Specifically } \\
\text { inhibits HOIP }\end{array}$ & $\begin{array}{l}\text { FDA approved } \\
\text { (Phase 4) }\end{array}$ & $\begin{array}{c}\text { Chronic } \\
\text { lymphocytic } \\
\text { leukemia, MM, } \\
\text { non-Hodgkin's } \\
\text { lymphoma [191], } \\
\text { and more }\end{array}$ & $\begin{array}{l}\text { Ovarian cancer, } \\
\text { MM, relapsed } \\
\text { T-cell lymphoma, } \\
\text { non-Hodgkin's } \\
\text { lymphoma, } \\
\text { Hodgkin's } \\
\text { lymphoma, and } \\
\text { more }\end{array}$ & [192-195] \\
\hline
\end{tabular}

\subsubsection{RING-Type E3 Ligases}

Targeting the MDM2-p53 Interaction

MDM2 (murine double minute 2) negatively regulates protein and transcriptional levels of the tumor-suppressive p53 (Figure 2) $[196,197]$ and, therefore, is frequently observed as mutated or overexpressed in many cancers [198]. Thus, it was hypothesized that inhibition of MDM2-mediated p53 degradation could impair tumor formation and growth, and several small-molecules have been identified to impede the p53-MDM2 interaction [199]. The Nutlins, discovered in 2004, are cis-imidazoline analogs which structurally mimic p53 to bind MDM2, thereby preventing their association [199]. Nutlin-3a is a particularly active member that has been reported to selectively induce p53-dependent apoptosis in glioblastoma and AML cells $[101,108]$ and also induce p53-independent mechanisms of tumor cell death $[200,201]$. Several preclinical studies have shown promising results for Nutlin-3a in targeting various solid tumors and hematological malignancies, either as a single treatment or in combination with other drugs [102,103,105-107]. Subsequently, the optimized Nutlin derivative RG7112 (aka RO5045337) [109] became the first MDM2 inhibitor to advance to clinical trials. Phase 1 trials investigating RG7112 against MDM2-amplified liposarcoma [111], solid tumors [112], and leukemia [110] reported limited efficacies and high incidences of adverse events, especially hematological toxicities. RG7388 (aka RO5503781, Idasanutlin) was developed in response to the required high doses and the side-effects associated with RG7112 [113]. Recently, Phase 1 results were published reporting promising in vivo efficacy of RG7388 in patients with polycythemia vera (PV) and essential thrombocythemia (ET) [114] and AML [115], where the treatments were well-tolerated aside from low-grade gastrointestinal toxicities. However, the first Phase 3 study of Idasanutlin, investigated in combination with cytarabine to treat $\mathrm{AML}$, was recently terminated based on interim efficacy results (study identifier NCT0254). 


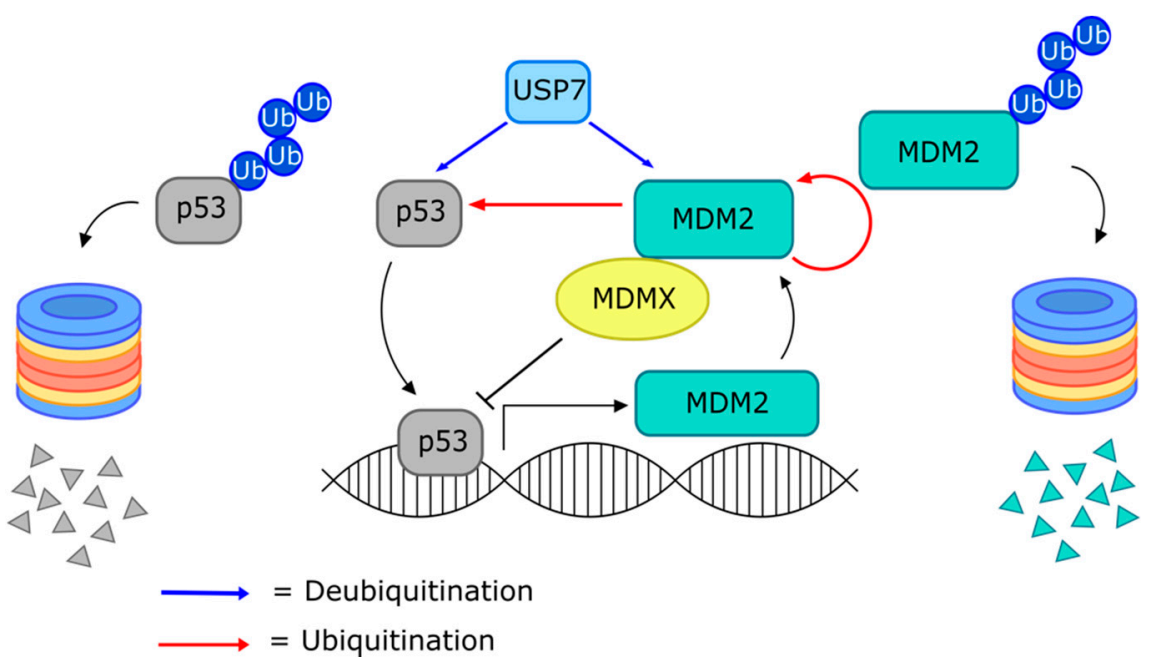

Figure 2. The USP7-MDM2-p53 axis. USP7 deubiquitinates both p53 and MDM2 but has stronger affinity for MDM2. MDM2 performs ubiquitination of p53 and self-ubiquitination. P53 promotes the expression of its target genes, including MDM2. MDMX can heterodimerize with MDM2 to facilitate p53 ubiquitination or directly block p53 action.

Many other small-molecule inhibitors of the MDM2-p53 interaction have been developed, and several clinical trials have recently published (Table 2). MI-77301 (aka SAR405838) is a molecule arising from affinity optimization of spirooxindole for binding to MDM2, and preclinical studies showed its ability to impair cell growth in a p53-dependent manner in acute leukemia, osteosarcoma, prostate, and colon cancer cell lines [117]. MI77301 was subjected to two clinical studies so far, with one suggesting safety and potential for use in combination treatments for advanced cancers, including solid tumors and lymphoma [118]. MK-8242 (aka SCH-900242) has been evaluated for treatment of AML [120] and advanced solid tumors [121], but limited efficacy was reported, and adverse events were common. AMG 232 has shown pre-clinical promise in vivo against various tumor xenografts and cell lines [123,124]. Clinical evaluation of AMG 232 for treatment of relapsed/refractory AML yielded promising results, despite some adverse effects noted at higher doses [125]. DS3032b is an MDM2 inhibitor that has been undergoing clinical evaluation for a number of years; two clinical trials were recently completed that have shown promising preliminary results $[128,129]$, but no further updates are available so far. HDM201 is an imidazolopyrrolidinone analogue that inhibits the p53-MDM2 interaction [202] and is currently being subjected to clinical evaluation alone or in combination treatments against various solid or hematological malignancies. Preliminary results reported good bioavailability and induced tumor regression in cancer cell and xenograft animal models [131,132]. Other MDM2 inhibitors currently undergoing clinical studies include APG-115 [134], APR-246 [138], and CGM097 [136]. Inhibitors of the p53-MDM2 interaction in preclinical stages include MI-63 [141], MI-219 [142], and the natural product sempervirine [143].

Some small-molecule inhibitors have been developed by directly targeting p53. One such compound is RITA (reactivation of p53 and induction of tumor cell apoptosis), which binds p53 directly and results in its accumulation in tumor cells [144]. Syl-155 [145] and HLI373 [146], on the other hand, are molecules that bind MDM2 in a competitive manner with p53 to cause accumulation. MDMX (murine double minute $X$ ) is another protein implicated in p53 regulation that can either bind p53 directly, blocking its transcriptional activity, or heterodimerize with MDM2 and facilitate p53 ubiquitination [203,204] (Figure 2). There is a need for dual inhibitors of MDM2/MDMX as it is highly expressed in some cancers [205,206]. NSC207895 [148] and MEL24 [147] are small molecules that target MDMX and have been shown to activate p53 and induce tumor cell apoptosis. 


\section{CRL/SCF RING E3 Ligases}

The SCF complexes are members of the CRL family of RING E3 ligases $[97,203]$. The variable F-box proteins (FBPs) are responsible for SCF substrate specificity and are often overexpressed in cancers or correlated with poor prognosis [204,205]. Drugs targeting components of various cancer-related SCFs, including FBXW7, SKP2, FBXO3, FBXL3, and $\beta$-TrCP1, have been developed [203]. Orodonin is a natural compound that promotes FBW7-mediated proteasomal degradation of the oncogenic c-MYC, inducing apoptosis in leukemia and lymphoma cells in preclinical studies [149]. SCF-I2 binds the substrateinteracting cleft of FBW7, allosterically inhibiting Cdc4 recognition, thereby impeding tumor progression in colon and prostate cancer models [150]. SMER3, a specific inhibitor of the FBP Met30 [206], was identified via screening for small molecules capable of enhancing rapamycin, which inhibits the activity of TOR (target of rapamycin), a protein kinase often overexpressed in human cancers [207-209]. SCF-SKP2 is thought to elicit oncogenic effects by promoting degradation of various tumor suppressors, including p27 [152,204]. Compound A [151]; SMIP004 [152]; and the compounds C1, C2, and C3 [153] are smallmolecule SKP2 inhibitors that have been shown to stabilize p27 in various preclinical cancer models. Many other molecules have reduced SKP2 expression in cancer cells, including SZL-P1-41 [154], longikaurin A [155], curcumin [156,157], and other natural compounds $[156,210-213]$. SCF- $\beta$-TrCP1 can induce proteasomal degradation of the inhibitor of nuclear factor- $\kappa \mathrm{B}(\mathrm{I} \kappa \mathrm{B})$ via ubiquitination, resulting in overexpression of NF- $\kappa \mathrm{B}$ signaling and tumorigenesis [214-216]. Inhibition of $\beta-\operatorname{TrCP} 1$ has been achieved by erioflorin, resulting in stabilization of tumor suppressor genes and decreased cancer cell proliferation [161]. GS143 operates similarly, inhibiting $\beta$-TrCP1-mediated I $\kappa$ B ubiquitination and suppressing NF- $\kappa$ B signaling [217].

\section{Other RING E3s}

RNF4 is a RING-type E3 ligase that promotes degradation of SUMOylated proteins via their ubiquitination [218]. An activity-based chemical library was screened against RNF4, and TRH 1-23 was identified as a binder with low inhibitory activity [162]. Using this ligand as a starting point, the analog CCW-16 was generated as a more potent RNF4 inhibitor. Subsequent addition of a linker to the BET bromodomain family inhibitor JQ1 generated CCW 28-3, a bifunctional degrader of RNF4, and interestingly, the final product showed even higher binding affinity for RNF4 than the CCW-16 ligand alone.

Inhibitor-of-apoptosis proteins (IAPs) inhibit apoptosis via suppression of caspase activity [219]. IAPs such as XIAP, cIAP1, and cIAP2 possess RING-finger domains and E3 ligase activity and are often overexpressed in many cancers $[163,219]$. Small-molecule mimetics of the IAP-inhibiting Smac proteins have been found to activate caspase and induce TNF $\alpha$ signaling [220]. GDC-0152 is a Smac mimetic that showed promising preclinical results in inhibiting tumor growth and inducing apoptosis of tumor cells [163], but clinical trials were terminated before proceeding from Phase I. Other IAP inhibitors that entered clinical trials include LCL161, AT-406, AEG 35156, AEG 40826, TL 32711, and YM155 [221]. Published results report that weekly oral doses of LCL161 was well-tolerated and efficacious in treating patients with advanced solid tumors, supporting further investigation [167]. Two publications have arisen from clinical evaluation of AT-406 (aka DEBIO1143, SM-406) against metastatic solid tumors [171] and head and neck cancers [172]. The recent Phase 2 study concluded that the addition of AT-406 augmented standard-of-care therapy with manageable safety, warranting Phase 3 investigation [172].

The tumor necrosis factor receptor-associated factor (TRAF) family of proteins are well-known as adaptor proteins important in cell signaling [222-224], but most TRAF proteins contain a RING domain, and some can act as E3 ligases [224,225]. TRAF6 is a RING E3 ligase whose overexpression has been implicated in lung cancer and osteosarcoma cells [226-228]. The binding of TRAF6 to the E2 enzyme Ubc13 results in the generation of K63-linked Ub chains that spur immune responses via NF- $k B$ signaling [179]. Researchers identified the molecule C25-140 through a high-throughput small-molecule screening 
approach and found it inhibits the TRAF6-Ubc13 interaction with high selectivity [179]. The molecule did not inhibit the action of other RING-type E3 ligases, nor tested HECT E3s. Through a different approach, researchers developed a series of molecules that decrease levels of TRAF6 [181]. BC-1215 is a small-molecule antagonist of FBXO3, which inhibits the degradation of Fbc12, which in turn, results in destabilization of TRAF6 and reduces cytokine-driven inflammation in mice [181].

\subsubsection{HECT-Type E3 Ligase Inhibitors}

HECT E3 ligases are associated with many types of human cancers, but discovery of small-molecule inhibitors for these targets has been limited, partly due to the poorlycharacterized binding surfaces of HECT E3s [229]. WWP2 (WW domain-containing E3 $\mathrm{Ub}$ protein ligase 2) is a NEDD4-family HECT E3 ligase that can cause degradation of tumor suppressor proteins PTEN and Oct4 in many cancers [230]. Researchers identified five potential small-molecule inhibitors through high-throughput screening (HTS) of a chemical library, representing the first generation of WWP2 inhibitors [230]. SMURF1 (SMAD Ub regulatory factor 1 ) is another NEDD4 HECT that targets tumor suppressor RhoB for degradation [182,231]. HS-152 is a small-molecule inhibitor discovered via a cell-based HTS approach that blocks the catalytic activity of SMURF1's HECT domains, stabilizing RhoB [182].

HUWE1 (HECT, UBA, and WWE domain-containing protein 1) is a regulator of several cancer-associated proteins, including MYC, p53, and MCL1, and its dysregulation or mutation is implicated in tumorigenesis [232]. Two relatively selective small-molecule inhibitors of HUWE1, BI8622 and BI8626, were identified via HTS and found to inhibit the growth of various colon cancer cell lines in vitro [183].

E6AP (E6-associated protein) is a HECT with well-documented roles in human papillomavirus (HPV)- and hepatitis C virus (HCV)-induced cancers. For example, E6AP can be hijacked by viral E6 protein to target p53 and/or retinoblastoma protein $(\mathrm{Rb})$ for proteasomal degradation, contributing to the development of malignancies [229]. Some small-molecule inhibitors targeting the E6AP-p53 interaction have been identified, such as compound 12 [185], which was shown to rescue p53 function and inhibit proliferation of $\mathrm{HPV}$ infected cells. Luteolin and CAF024 are two flavonoid compounds that may prevent the hijacking of E6AP by binding to the hydrophobic binding groove of the viral E6 protein and preventing its association with E6AP [186]. Recently, a rational in silico screening strategy yielded three promising small-molecule inhibitors, termed Lig1, Lig2, and Lig3 [233]. $\mathrm{N}$-acetyl phenylalanine prevents the trimerization of E6AP and inhibits its E3 functionality, albeit at high concentrations $[229,234]$. Finally, CM11- 1 is a macrocyclic N-methyl peptide inhibitor that has been shown to prevent the polyubiquitination of Prx1 and p53 by E6AP in a RaPID cell-free system [235].

Using a phage display method, bicyclic peptide inhibitors of HECT domains were identified that prevented E2 binding by SMURF2, WWP1, and other HECT E3 ligases [236]. Researchers screened for small molecules capable of displacing one of the peptides from SMURF2 and discovered a compound, termed Heclin (HECT ligase inhibitor), that caused a conformational change in the HECT domain to prevent its activity. Heclin indiscriminately inhibited HECT ligases in vitro and killed growing HEK293 cells, but the approach could potentially be used to find more specific inhibitors.

\subsubsection{RBR-Type E3 Ligase Inhibitors}

RBRs are the least frequently targeted class of E3 ligases for inhibitor development so far. The RBR structures, mechanisms, and relevance to cancer are less well-understood compared to the RING and HECT E3s, and the topic has been recently reviewed [237].

LUBAC (linear Ub chain assembly complex), consisting of HOIP, HOIL-1L, and SHARPIN, is the only E3 ligase known to perform polyubiquitination via Met1 linkages [238-241]. LUBAC activity and mutation is implicated in various diseases, including activated B cell-like diffuse large B cell lymphoma (ABC-DLBCL) [242]. BAY11-7082 [187], 
gliotoxin [243], and HOIPIN-8 [189] are three compounds reported to inhibit LUBAC. Bendamustine, an FDA-approved chemotherapeutic for leukemia and lymphoma, has been classified as an alkylating agent but was also found to selectively inhibit HOIP [244]. Three other small molecules that displayed promising selectivity for HOIP were identified via a covalent ligand screen [245]. Finally, the recent development of a strategy using singledomain antibodies (dAbs) shows promise for expeditious rational design of inhibitors for RBRs [246]. Tsai et al. (2020) screened a synthetic library of dAbs to obtain tight binders of the RBR domain of HIOP and solved the co-crystal structure of one complex to demonstrate the platform's amenability to ligand-soaking [246].

\subsection{Chemical Inhibitors of DUBs}

DUBs reverse the action of the E3 ligases by editing or removing $\mathrm{Ub}$ chains via their proteolytic activity [19-21]. Thus, inhibiting DUBs can promote the selective degradation of proteins by preventing the removal of their $\mathrm{Ub}$ tags. The target specificities and defined catalytic sites of DUBs make them easy to screen against small-molecule libraries and therefore became attractive therapeutic targets [247,248]. Multiple small-molecule DUB inhibitors have been reported, albeit with limited selectivity until recently [58]. Below, we summarize the discovery of inhibitors for the most popular DUB target, USP7, and highlight recent progress in the development of other DUB inhibitors (Table 3).

\subsubsection{USP7 Inhibitors}

The largest family of DUBs, the USPs, are characterized by a catalytic USP domain of variable size containing six conserved motifs [247]. USP7 deubiquitinates various substrates implicated in numerous cellular processes, but its important and paradoxical role in the p53-MDM3 axis has made it a popular target for cancer therapeutics [249]. On one hand, USP7 deubiquitinates and stabilizes p53, reversing the action of MDM2 [250]. However, USP7 can also stabilize MDM2 by opposing its auto-ubiquitination. Interestingly, when cellular USP7 levels are decreased, the net result is destabilized p53, but when USP7 activity is abolished, MDM2 is downregulated, stabilizing p53 [251] (Figure 2). Thus, discovery of potent small-molecule USP7 inhibitors is a long sought-after avenue for cancer therapeutics.

The first generation of small-molecule USP7 inhibitors included HBX 41,108; HBX 19,818; HBX 25,258; P5091; P50429; and P22077. HBX 41,108 was the first inhibitor of USP7 to be identified. It uncompetitively and reversibly inhibited USP7 but had poor selectivity [249]. HBX 19,818 was later shown to covalently bind the active site of USP7, selectively and irreversibly inhibiting its activity, resulting in increased p53 levels in human cancer cells, inducing apoptosis in a dose-dependent manner [252]. HBX 28,258 also inhibited USP7 by the same mechanism. Another group discovered P5091, which is selective for USP7, which caused apoptosis of Bortezomib-resistant MM cells and prolonged survival in mouse models [253]. P5091 is, in fact, a dual inhibitor of USP7 and USP47 [254]. Optimization of P5091 led to P50429 [254] and P22077 [255,256], which bind irreversibly to the catalytic cysteine C223 of USP7. However, none of these "first-generation" USP7 inhibitors had optimal potency or specificity $[257,258]$, perhaps as a result of their activitybased discovery approach. 
Table 3. Small-molecule inhibitors of the deubiquitinases (DUBs).

\begin{tabular}{|c|c|c|c|c|c|}
\hline Compound Name & UPS Target & Mode of Action & $\begin{array}{c}\text { Current Clinical } \\
\text { Stage }\end{array}$ & $\begin{array}{c}\text { Cancer Models } \\
\text { Targeted in } \\
\text { Preclinical } \\
\text { Studies }\end{array}$ & $\begin{array}{l}\text { Clinical Trial } \\
\text { Cancer Targets }\end{array}$ \\
\hline $\begin{array}{c}\text { HBX 41108, HBX } \\
19818, \text { HBX } 28258\end{array}$ & USP7 & $\begin{array}{l}\text { Covalently binds } \\
\text { USP7 active site, } \\
\text { increasing p53 }\end{array}$ & Preclinical & $\begin{array}{l}\text { Colon cancer cell } \\
\text { lines }[249,252]\end{array}$ & $\mathrm{N} / \mathrm{A}$ \\
\hline P5091 & USP7 and USP47 & $\begin{array}{l}\text { Dual inhibitor of } \\
\text { USP7 and USP47 }\end{array}$ & Preclinical & $\begin{array}{c}\text { MM cells, } \\
\text { bortezomib- } \\
\text { resistant MM, and } \\
\text { B-cell leukemia } \\
\text { mouse models } \\
\text { [253] }\end{array}$ & $\mathrm{N} / \mathrm{A}$ \\
\hline P50429, P22077 & USP7 & $\begin{array}{l}\text { Irreversibly bind } \\
\text { catalytic cysteine } \\
\text { residue of USP7 }\end{array}$ & Preclinical & $\begin{array}{c}\text { Colon cancer cell } \\
\text { line [254], } \\
\text { neuroblastoma } \\
\text { xenograft [255] }\end{array}$ & $\mathrm{N} / \mathrm{A}$ \\
\hline Compound 4 & USP7 & $\begin{array}{l}\text { Selectively binds } \\
\text { USP7 allosteric site }\end{array}$ & Preclinical & $\begin{array}{l}\text { Leukemia, prostate } \\
\text { adenocarcinoma } \\
\text { cell lines [259] }\end{array}$ & $\mathrm{N} / \mathrm{A}$ \\
\hline $\begin{array}{l}\text { GNE-6640, } \\
\text { GNE-6776 }\end{array}$ & USP7 & $\begin{array}{l}\text { Binds novel USP7 } \\
\text { functional site }\end{array}$ & Preclinical & $\begin{array}{l}\text { Colon cancer cells } \\
\text { [260] }\end{array}$ & $\mathrm{N} / \mathrm{A}$ \\
\hline XL188 & USP7 & $\begin{array}{l}\text { Non-covalent } \\
\text { inhibition of USP7 } \\
\text { active site, causing } \\
\text { accumulation of } \\
\text { p53 and p21 }\end{array}$ & Preclinical & $\begin{array}{l}\text { Breast cancer and } \\
\text { MM cell lines [261] }\end{array}$ & $\mathrm{N} / \mathrm{A}$ \\
\hline FT671, FT827 & USP7 & $\begin{array}{l}\text { Allosteric USP7 } \\
\text { inhibition }\end{array}$ & Preclinical & $\begin{array}{c}\text { Colon cancer, } \\
\text { osteosarcoma cell } \\
\text { lines, MM cells, } \\
\text { and xenografts } \\
\text { [262] }\end{array}$ & $\mathrm{N} / \mathrm{A}$ \\
\hline $\begin{array}{l}\text { Pimozide and } \\
\text { GW7647 }\end{array}$ & $\begin{array}{l}\text { USP1/UAP1 } \\
\text { complex }\end{array}$ & $\begin{array}{l}\text { Non-competitive } \\
\text { inhibition of USP1 }\end{array}$ & Preclinical & NSCLC cells [263] & $\mathrm{N} / \mathrm{A}$ \\
\hline $\begin{array}{l}\text { IU1, IU1-47, 1B10, } \\
\text { IU1-248 }\end{array}$ & USP14 & $\begin{array}{l}\text { Binds USP14 steric } \\
\text { site }\end{array}$ & Preclinical & $\mathrm{N} / \mathrm{A}$ & $\mathrm{N} / \mathrm{A}$ \\
\hline b-AP15 & USP14 and UCHL5 & $\begin{array}{c}\text { Blocks 19S DUB } \\
\text { activity }\end{array}$ & Preclinical & $\begin{array}{c}\text { Solid tumors, MM } \\
{[40,72-74]}\end{array}$ & $\mathrm{N} / \mathrm{A}$ \\
\hline VLX1570 & USP14 and UCHL5 & $\begin{array}{c}\text { b-AP15 analog, } \\
\text { also blocks 19S } \\
\text { DUBs }\end{array}$ & $\begin{array}{l}\text { Preclinical (Phase } \\
1 / 2 \text { terminated) }\end{array}$ & MM [42] & $\begin{array}{l}\text { Multiple Myeloma } \\
\text { (MM) }\end{array}$ \\
\hline Capzimin, 8TQ & Rpn11 & $\begin{array}{c}\text { Specific inhibitors } \\
\text { of Rpn11 }\end{array}$ & Preclinical & $\begin{array}{c}\text { Leukemia, NSCLC, } \\
\text { breast cancer [79] }\end{array}$ & $\mathrm{N} / \mathrm{A}$ \\
\hline Thiolutin, SOP11 & $\begin{array}{c}\text { Rpn11 } \\
\text { (nonspecific) }\end{array}$ & $\begin{array}{c}\text { Non-specifically } \\
\text { inhibits } \\
\text { JAMM-family } \\
\text { DUBs }\end{array}$ & Preclinical & $\begin{array}{c}\text { Colon cancer, } \\
\text { bortezomib- } \\
\text { resistant RPE cells } \\
{[80]}\end{array}$ & $\mathrm{N} / \mathrm{A}$ \\
\hline
\end{tabular}


Table 3. Cont.

\begin{tabular}{|c|c|c|c|c|c|}
\hline Compound Name & UPS Target & Mode of Action & $\begin{array}{c}\text { Current Clinical } \\
\text { Stage }\end{array}$ & $\begin{array}{l}\text { Cancer Models } \\
\text { Targeted in } \\
\text { Preclinical } \\
\text { Studies }\end{array}$ & $\begin{array}{l}\text { Clinical Trial } \\
\text { Cancer Targets }\end{array}$ \\
\hline $\begin{array}{l}\text { Celasterol, } \\
\text { mangaferin }\end{array}$ & UCHL1 & $\begin{array}{c}\text { Reversible } \\
\text { inhibitors of } \\
\text { UCHL1 }\end{array}$ & Preclinical & $\mathrm{N} / \mathrm{A}$ & $\mathrm{N} / \mathrm{A}$ \\
\hline $\begin{array}{l}\text { LDN-57444, } \\
\text { LDN-Pox }\end{array}$ & UCHL1 & $\begin{array}{l}\text { Incorporation of } \\
\text { LDN-57444 in Pox } \\
\text { micelle delivery } \\
\text { system inhibits } \\
\text { UCHL1 in cells }\end{array}$ & Preclinical & $\begin{array}{c}\text { Oral squamous cell } \\
\text { carcinoma cell line } \\
\text { [264] }\end{array}$ & $\mathrm{N} / \mathrm{A}$ \\
\hline 6RK73 and 8RK64 & UCHL1 & $\begin{array}{l}\text { Cell penetrable } \\
\text { probes bind } \\
\text { UCHL1 active site } \\
\text { cysteine in } \\
\text { activity-dependent } \\
\text { manner }\end{array}$ & Preclinical & $\mathrm{N} / \mathrm{A}$ & $\mathrm{N} / \mathrm{A}$ \\
\hline WP1130 & USP9X & $\begin{array}{l}\text { Inhibits USP9X, } \\
\text { UCHL, and USP14 } \\
\text { to a degree }\end{array}$ & Preclinical & $\begin{array}{c}\text { CML, melanoma, } \\
\text { glioblastoma, } \\
\text { myeloproliferative } \\
\text { disorders } \\
{[44,75,76], \text { MCL }} \\
\text { [77], AML [78] }\end{array}$ & $\mathrm{N} / \mathrm{A}$ \\
\hline EOAI3402143 (G9) & $\begin{array}{l}\text { USP9X/USP24 } \\
\text { (and partially } \\
\text { USP5) }\end{array}$ & WP1130 analog & Preclinical & $\begin{array}{c}\text { AML [78], MM } \\
\text { [265], melanoma } \\
\text { [76] }\end{array}$ & $\mathrm{N} / \mathrm{A}$ \\
\hline FT709 & USP9X & $\begin{array}{l}\text { Competitively } \\
\text { binds USP9X } \\
\text { active site }\end{array}$ & Preclinical & $\begin{array}{l}\text { Colon cancer cell } \\
\text { line [266] }\end{array}$ & $\mathrm{N} / \mathrm{A}$ \\
\hline OTUB2-COV-1 & OTUB2 & $\begin{array}{l}\text { Covalent OTUB2 } \\
\text { inhibitor }\end{array}$ & Preclinical & $\mathrm{N} / \mathrm{A}$ & $\mathrm{N} / \mathrm{A}$ \\
\hline BC-1471 & STAMBP & $\begin{array}{l}\text { Inhibits STAMBP, } \\
\text { prevents } \\
\text { interaction with } \\
\text { NALP7 }\end{array}$ & Preclinical & $\mathrm{N} / \mathrm{A}$ & $\mathrm{N} / \mathrm{A}$ \\
\hline
\end{tabular}

Almost a decade later, several potent and selective allosteric USP7 inhibitors were identified by different groups simultaneously through combination of fragment-based screens and structure-guided medicinal chemistry optimization. This strategy is likely to have general applicability for targeting other USP DUBs in the future. Gavory and colleagues first identified "Compound 1" through small-molecule fragment-based screening utilizing surface plasmon resonance (SPR), followed by specific modifications based on features of other known USP7 inhibitors [259]. Subsequent medicinal chemistry-based design produced "Compound 4", which noncompetitively binds an allosteric site distal to USP7's catalytic site. Compound 4 exhibited $\sim 2000$-fold increased potency over Compound 1, showed good cell permeability, and various cancer cells were found to be hypersensitive to the compound [259]. The allosteric inhibition mechanism could be part of the reason for Compound 4's dramatic potency and selectivity [267], and it might exploit mechanistic features of USP7 related to the conformational changes that occurred following Ub binding [258]. Another group similarly utilized NMR-based screening, followed by structure-based design, to generate the allosteric modulators GNE-6640 and GNE-6776 [268]. The compounds prevented Ub from interacting with USP7 by binding its catalytic domain at a novel functional site $12 \AA$ away from the catalytic cysteine 
residue [268]. They showed potent inhibition with high selectivity for USP7 and proved capable of inducing tumor cell death $[260,268]$. Lamberto et al. used structure-based design to optimize a previously identified small-molecule that had high specificity for USP7 but weak potency [261]. XL188 non-covalently inhibited the active site of USP7 with 100-fold higher potency than the original lead and was shown to increase the expression of p53 and of downstream tumor suppressor p21, resulting in impaired tumor growth [261]. Finally, Turnbull et al. (2017) reported FT671 and FT827 as specific allosteric inhibitors of USP7 with high affinity exhibited in vitro and in human cells [262]. In an approach similar to other groups, a small-molecule library was screened for binding and inhibitory activity against USP7, followed by structure-guided optimization. FT671 exhibited in-cell results consistent with successful USP7 inhibition and compromised tumor growth in a p53-dependent manner in a mouse model [262].

\subsubsection{Other DUB Inhibitors}

USP1 is a DUB whose catalytic activity is stimulated upon complex formation with UAF1 [269]. One of its targets is FANCD2, which has essential functions in the DNA repair pathway [270]. As a pharmacological target, inhibition of the USP1/UAF1 complex was proposed to impair tumorigenesis in malignant osteosarcoma and sensitize cells to chemotherapy [248]. Two small molecules, pimozide and GW7647, were identified in 2011 [263] and found to non-competitively inhibit USP1 and inhibit proliferation of cisplatin-resistant NSCLC cells in combination treatment with cisplatin.

USP14 is one of three proteasome-associated DUBs that perform their deubiquitination activities at the proteasome and are important therapeutic targets for chemical inhibition [247]. USP14 reversibly associates with the proteasome and inhibits the degradation of proteasome-targeted proteins via trimming of their $\mathrm{Ub}$ chains [40], and its dysregulation has been implicated in tumorigenesis and neurodegenerative disorders [58]. IU1 is a selective inhibitor of USP14, identified via a small-molecule HTS strategy, that was shown to promote the degradation of proteins, including the neurodegenerative diseaseassociated proteins Tau and ataxin-3 [40]. IU1-47 is one of 87 variants of IU1 developed by Boselli et al. (2017), with 10-fold higher potency and retained selectivity for USP14 inhibition [271]. Another IU1 analog, 1B10, also has heightened potency, as well as better membrane permeability [272]. IU1-248 was also recently discovered to be around 10-fold more potent than IU1 [72]. Interestingly, structural analysis revealed that this family of molecules functions by binding a previously unknown steric site on USP14. b-AP15 is an inhibitor of USP14 and another proteasome-associated DUB, UCHL5 [73]. b-AP15 selectively blocks $19 \mathrm{~S}$ regulatory particle DUB activity and has been shown to induce tumor cell apoptosis in various solid tumor types, as well as MM [41,73,74,273]. VLX1570 is an optimized lead of b-AP15 that also inhibits USP14 and UCHL5 [42], but limiting toxicities terminated clinical trials (study identifier NCT02372240). Rpn11 is the third proteasome-associated DUB [274]. Several small-molecule inhibitors of Rpn11 have been identified, including 8TQ and Capzimin $[79,275]$. Non-specific inhibitors of Rpn11 include SOP11, an epidithiodiketopiperazine molecule [80], and thiolutin, a naturally-occurring antibiotic [276], which both also inhibit other JAMM family DUBs.

Recently, UCHL1 became a popular target for inhibition in many cancers, as well as neurodegenerative diseases and liver and lung fibrosis [58]. Interestingly, Ott et al. (2017) utilized a fluorometric cell lysate-based assay called AlphaLisa to develop UCHL1 inhibitors as proof-of-principle for this strategy, yielding a series of inhibitory compounds, the most selective being celasterol and mangaferin [277]. LDN-57444 is an isatin O-acyl oxime molecule identified through HTS and medicinal chemistry that selectively inhibits UCHL1 [278]. Both LDN-57444 and its soluble version LDN-Pox exhibited anti-metastatic effects against oral squamous cell carcinoma (OSCC) cell line [264]. Finally, two selective inhibitors of UCHL1 called 6RK73 and 8RK64 were recently synthesized for the purpose of developing activity-based probes to monitor UCHL1 activity in cell systems [279]. 
USP9X is a DUB that stabilizes the oncogenic MCL-1 in cancer cells [280] and was shown to be overexpressed in MM [281]. WP1130 [282] is a DUB inhibitor with some selectivity for USP9X that was shown to reduce MCL-1 and induce cancer cell apoptosis, as well as reduce chemoresistance in various tumor types $[44,75,283]$. However, upregulation of USP24 in response to USP9X knockdown, promoting myeloma cell survival, demonstrated the need for dual USP9X/USP24 inhibitors, prompting the development of EOAI3402143 (aka G9) by improving the properties of WP1130 [265]. Both WP1130 and G9 also partially inhibit another DUB, USP5, but the resultant p53 accumulation only enhances anti-tumor effects in MM [265]. Recent preclinical results have shown WP1130 and G9 to be effective at inducing apoptosis in other cancers, such as AML [78] and melanoma [76]. More recently, FT709 [266] was identified as a potent inhibitor of USP9X, with greatly extremely improved specificity compared to WP1130.

OTUB2 (otubain-2) has been shown to be associated with various human diseases [284-286], including cancer, in which its deubiquitination of transcriptional regulators YAP and TAZ promotes metastasis [287]. OTUB2 preferentially cleaves Lys63-linked poly-Ub chains but also has activity against Lys11- and Lys48-linked chains [288]. Recently, an electrophilefragment screening approach was used to discover the first covalent inhibitor for OTUB2, termed OTUB2-COV-1 [289]. STAMBP is another Lys63-specific DUB, for which the small molecule BC-1471 was reported to be a potent and specific inhibitor [290]. Finally, many broad-spectrum DUB inhibitors, such as chalcone molecules G5 and F6 [291], PR-619 [256], and betulanic acid [292] have been discovered, but unspecific inhibition of DUBs can result in undesirable off-target effects and high toxicities, making them unideal for clinical application [293].

\section{Targeted Protein Degradation}

The chemical compounds described above fit the classical pharmacological model, where small molecules bind an active or allosteric site of a protein target to interfere with its catalytic function. While traditionally this is a reasonable approach, it has been pointed out that this model limits the druggable protein space, because less than $25 \%$ of the human proteome consists of proteins that can be targeted in this way [294-299]. Moreover, the so-called "occupancy-driven" approach requires high drug concentrations for inhibition, leading to unwanted toxicities and off-target effects $[297,298,300]$. A promising alternative strategy is targeting natural protein-protein interactions (PPIs) instead of focusing on ligand-binding sites [33]. The shift to an "event-driven" pharmacological model will expand the druggable space to include a much wider spectrum of proteins involved in critical cellular functions and pathologies [33,297,300]. By exploiting UPS machinery to capitalize on transient PPIs, selective degradation of protein targets can be achieved. Indeed, proteolysis-targeting-chimeras (PROTACs) are rapidly emerging as a technology holding great promise for cancer treatment [296,298,300-303].

\subsection{PROTACS}

A proteolysis-targeting chimaera (PROTAC) is a bivalent molecule comprising two selective binding moieties (termed "warheads") to recruit a protein target and an E3 ligase, which are linked together so that the target will be brought to close proximity of the E3 ligase for its ubiquitination (Figure 3) [298,301]. PROTACs have been shown in vitro and in vivo to deplete target proteins in a rapid and sustained fashion, providing a significant advantage versus small-molecule-based protein inhibition, where compensatory responses can increase target concentrations over time [304,305]. Other noteworthy advantages of PROTACs are their high selectivity, their ability to bypass the challenge of drug resistance due to mutated active sites, and the fact that the toolkit of possible warheads is vast due to the ability to use agonists, antagonists, or non-modulatory binders of the target at hand [306]. Finally, since PROTACs degrade rather than inhibit their targets, they are effective even at very low concentrations (in some cases 1000 times lower than traditional 
drugs) [302]. In the following sections, we will briefly summarize the history of PROTAC optimization and highlight recent developments and considerations.

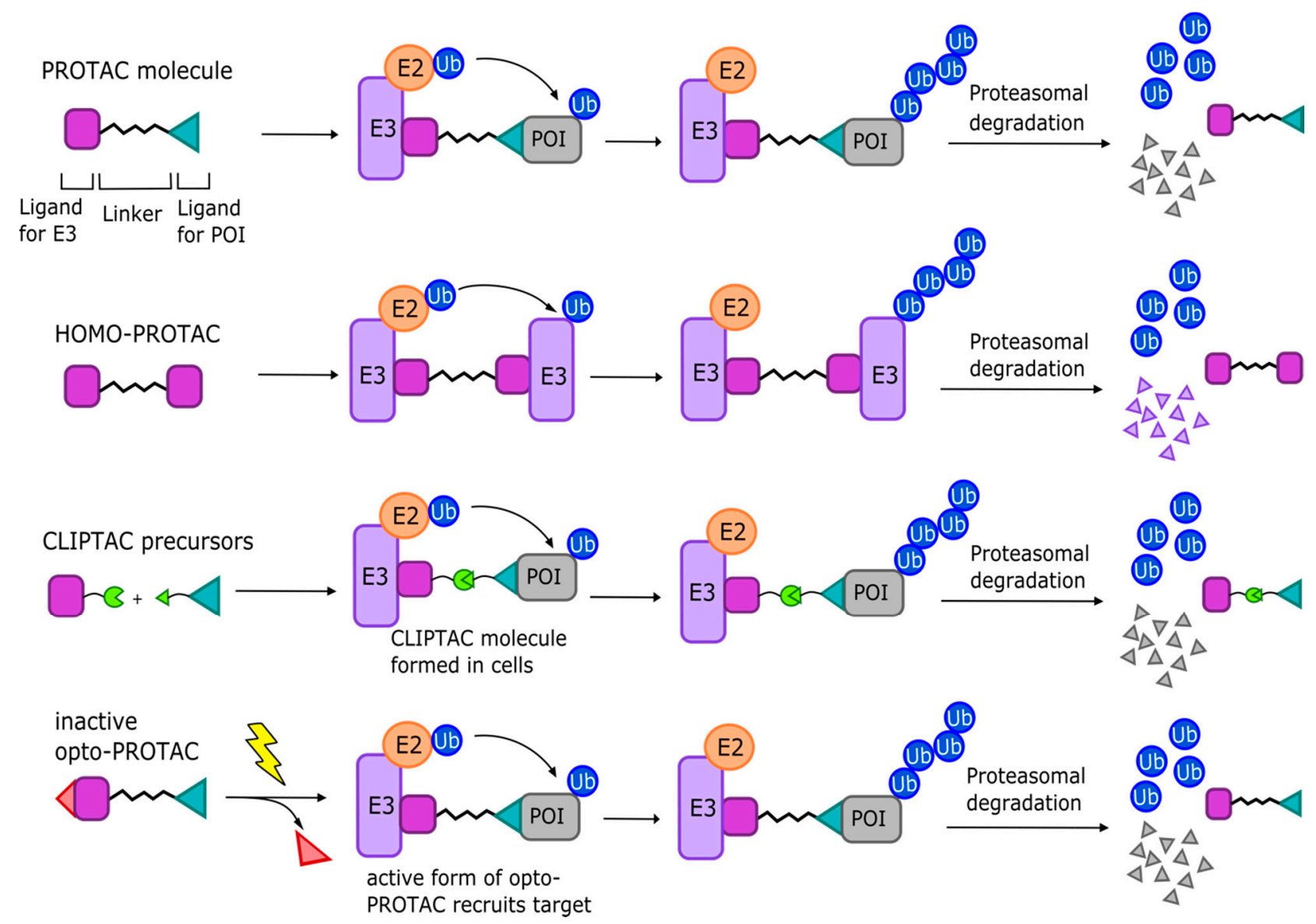

Figure 3. Schematic of the mode of action of PROTAC and selected variations. PROTAC (proteolysis-targeting chimera) molecules consist of a ligand for recruiting an E3 ligase and a ligand for recruiting a POI connected by a linker. PROTAC molecules and their variations aim to orient the POI in proximity to the E3 ligase to facilitate its ubiquitination and proteasomal degradation, after which the PROTAC can be used again. Homo-PROTACs contain two identical E3-recruiting moieties to perform E3 ubiquitination. CLIPTACs consist of cell-permeable precursors that join together via click-chemistry to form an active molecule in cells. Opto-PROTACs, photo-PROTACs, or PHOTACs are activated by UVA or visible light to recruit their targets in cells.

\subsubsection{First Generation PROTACs}

Early PROTACs were peptide-based, which had limitations due to instability, poor cell permeability, and low activity [300]. The first PROTAC was developed by Sakamoto et al. (2001) and used a peptidic recruiter of the E3 ligase SCF- $\beta$-TRCP [301]. IKB $\alpha$ is a natural target of SCF- $\beta$-TRCP, and its recruitment is mediated by a phosphorylated 10-aa sequence within I $B \alpha$, DRHDSGLDSM [307]. Sakamoto and colleagues exploited this IкB $\alpha$ phosphopeptide (IPP) as a SCF- $\beta$-TRCP ligand in the pioneering PROTAC study [301]. PROTAC-1, as it was termed, consisted of the IPP warhead linked to ovacilin, a covalent binder of MetAP-2. While it did induce degradation of MetAP in Xenopus extracts, it was not cell permeable, and its application was limited by instability of the molecule. Subsequently, PROTACs targeting the nuclear receptors AR and ER were developed but still required microinjection to function in cells [308]. In 2004, a PROTAC was developed that was capable of permeating cells due to the inclusion of a poly-D-arginine cell penetrating peptide [309]. Schneekloth et al. (2004) linked peptidic ligands for the E3 VHL and 
the target FK506 binding protein (FKBP), and the resulting PROTAC degraded FKBP in cells [309].

\subsubsection{Development of Small-Molecule PROTACs}

The second generation of PROTACs employed small-molecule warheads instead of peptides, first exemplified by the use of Nutlin-3a to recruit MDM2 and a selective androgen receptor modulator (SARM) ligand to target the androgen receptor (AR) [310]. This PROTAC's activity was still limited, requiring micromolar concentrations, but it partially degraded AR in cells. Researchers continued to search for ways to decrease size and employ novel E3 ligase recruiters for new PROTACs. The discovery of the pthalimide immunomodulatory drugs (IMiDs) as binders of cereblon (CRBN) in 2010 [311], shortly followed by the optimization of potent synthetic ligands for VHL, provided new tools for PROTAC development and significantly advanced the field forward [312-315].

The small-molecule VHL ligands were first utilized by Buckley et al. (2015) to degrade HaloTag7 (HT7)-GFP fusion proteins [316]. Incorporation of the VHL ligand in a socalled HaloPROTAC, along with a chloroalkane linker that binds HT7, resulted in GFP fluorescence depletion in cells. Bondeson et al. (2015) employed the VHL ligand to create PROTACs targeting estrogen-related receptor alpha (ERR $\alpha$ ) and the serine-threonine kinase RIPK2, and their activities were proven by the depletion of ERR $\alpha$ in breast cancer cells and depletion of RIPK2 in monocytes [302]. Furthermore, this study showed the first successful in vivo PROTAC results by the reduction ( 40\%) of ERR $\alpha$ in mouse tumors following intraperitoneal injection. Another study [317] used a VHL ligand-based PROTAC to degrade the bromo- and extra-terminal (BET) protein BRD4, which has been strongly linked to cancers, including AML and ovarian carcinoma [318-320]. By linking the VHL ligand to the BET inhibitor JQ1, the compound MZ1 was created, which induces selective degradation of BRD4 over BRD2 and BRD3 in cells [317]. Raina et al. (2016) also linked JQ1 to VHL ligand to produce the potent ARF-771, with high efficacy against castration-resistant prostate cancer (CRPC) models, showing the first successful application of PROTACs against solid tumor types [321].

Around the same time in 2015, two groups reported PROTACs employing IMiDs to recruit CRBN. The BRD4 inhibitor OTX015 was linked to pomalidomide to generate ARV-825, which reduced BRD4 in a superior manner to OTX015 alone in lymphoma cell lines [322]. Winter et al. (2015) utilized JQ1 tethered to a thalidomide derivative to produce ABET1, which reduced BET proteins, induced apoptosis of AML and lymphoma cells, and delayed leukemia progression in a mouse model [323]. Interestingly, by using only a different linker compared to the Zengerle et al. (2015) study [317], no preferential selectivity for BRD4 was observed by Winter et al. (2015), suggesting the importance of linker geometry in ternary complex formation and target specificity [323].

Recent progress in the field of small-molecule PROTACs has been thoroughly reviewed elsewhere [300,303,324-326]. While CRBN [327-339] and VHL [340-350] ligands are still by far the most utilized to recruit E3 ligases in PROTACs, other E3 ligases have been employed in small-molecule PROTACs, including MDM2 [351-353], KEAP1 [354], DCAF16 [355], RNF4 [162], and RNF114 [356]. It is noteworthy that two PROTACs, ARV-110 and ARV-471, entered clinical trials recently (study identifiers NCT03888612 and NCT04072952). These PROTACs, developed by Arvinas LLC, have proprietary structures, but ARV-110 targets AR, ARV-471 targets ER $\alpha$, and both have shown successful degradation of their targets in cell lines and mouse models for prostate cancer and breast cancer, respectively $[357,358]$.

\subsubsection{PROTAC Variations}

Another class of PROTAC-like molecules is the specific and non-genetic IAP-dependent protein erasers (SNIPERs). The first of these capitalized on the discovery that methyl bestatin (MeBS) interacts with cIAP1 and induces its autoubiquitination [359]. Researchers added a ligand for the target protein, cellular retinoic acid binding proteins (CRABPs) I and II, to the methyl residue of MeBS. Consequently, the first SNIPERs induced the 
simultaneous degradation of the recruited E3 and the target proteins [359]. This could be useful in targeting cancer cells where IAP E3 ligases are overexpressed [360]. However, in further developments of SNIPERs, researchers replaced an ester group with an amide group at the linker attachment site of MeBS to circumvent the autoubiquitination [361]. Subsequently, many SNIPERs have been developed with various target protein ligands, such as ER $\alpha$ [362,363], AR [364], and BRD4 [365]. We noted that SNIPERs have been reviewed extensively elsewhere [360].

Other variations of PROTACs have been developed as well (Figure 3). HomoPROTACs hijack E3 ligases to induce their self-degradation [366-368]. The first of these was developed by the Ciulli group in 2017 and induced the dimerization and auto-degradation of VHL, potentially serving as a useful research tool [366]. Another PROTAC variation, called CLIPTACs, or in-cell click-formed proteolysis targeting chimeras, were developed in an attempt to overcome the cell permeability issue [369]. CLIPTACs assemble intracellularly by click-chemistry following cell treatment with cell-permeable precursors. In 2016, this approach proved successful in the development of CLIPTACs that degraded protein targets BRD4 and ERK1/2 [369]. Interestingly, recent research has developed PROTACs that can be activated by UV or visible light, termed photo-PROTACs, opto-PROTACs, or PHOTACs [370-373]. These could be applied clinically to directly target tumors via photodynamic therapy (PDT), providing an encouraging new development for the field of photomedicine.

\subsubsection{PROTAC Future Directions}

Careful consideration of the design and optimization of PROTACs for clinical safety and efficacy has been thoroughly reviewed [300,374-377]. It is notable that the stability of the ternary complex (target-PROTAC-E3) is potentially more important than the binary affinities of each warhead for efficient target degradation [300,302]. The favorable or repulsive interactions between PROTAC components and the substrate protein lead to positive or negative cooperativity, which in turn influence the stability of the ternary complex $[300,378]$. For example, the crystal structure of a BRD4-degrading PROTAC's ternary complex revealed cooperativity via van der Waals contacts between BRD4 and both the VHL warhead and the linker, which heightened the PROTAC's specificity and potency [340]. While, historically, the linker design received much less attention, it is now becoming increasingly clear that linker composition is one of the most important factors contributing to PROTAC cellular activity, as linker length and attachment location can influence ternary complex conformation, target selectivity, and cell permeability [297,302,379]. Further advancement in computational analysis and structure-based optimization methods will likely result in better PROTAC linker design. A more extensive overview of the different linker classes, effects on the multiple aspects of PROTACs properties, and emerging design principles can be found here [380,381].

Expanding the repertoire of PROTAC warheads will enable the recruitment of more E3 ligases and the degradation of more protein targets. There is opportunity to utilize low affinity molecules or resurrect discarded "near-drugs", optimized binders that failed clinical trials, for inclusion as PROTAC warheads [297]. Screening small-molecule libraries for binders of target proteins without active sites will allow PROTACs to engage more diverse protein types. Protein engineering strategies could also be employed to develop warheads against E3 ligases or target proteins that have no small-molecule binders to date. Expanding the toolbox of E3 ligases will be critical for future PROTAC development, as only a handful of the over 600 human E3 ligases have been employed so far [377]. When choosing an E3 ligase, an important consideration is that it must be present in the target tissue or cell type for the PROTAC to be active, adding complexity as well as presenting an opportunity for tissue-specific applications [377]. For example, there are four human E3 ligases currently known to be expressed in specific tissues that also induce proteasomal degradation of protein targets. Recruitment of these in PROTACs against various cancerassociated targets could mediate tissue-specific degradation without effecting normal cells 
in other tissues [377]. As progress in the field of PROTACs continues to be made, care must be taken to investigate the efficacy, specificity, and pharmacological properties of each newly developed drug. Expansion of in vivo data and available pharmacokinetic and pharmacodynamic analysis models will be essential to bring PROTACs closer to clinical application [376].

\subsection{Other Notable Approaches to Targeted Protein Modulation}

The IMiDs, mentioned above as CRBN ligands in PROTACs, are successful mediators of targeted protein degradation in their own right. As "molecular glues", they can bring the CRL4-CRBN E3 ligase complex together with substrates including Ikaros, Aiolos and CK1 $\alpha$ to mediate their degradation $[311,382,383]$. Thalidomide, and its derivatives lenalidomide and pomalidomide, are FDA-approved for use against various hematological malignancies [311,383-385]. Other molecules currently undergoing clinical studies are avadomide and iberdomide [386,387]. Indisulam, tasisulam, and chloroquinoxaline sulfonamide (CQS, aka NSC 339004) are aryl sulfonamide molecules that induce the association of nuclear protein RBM39 with the E3 ligase complex Cul4-DCAF15, inducing its proteasomal degradation in a manner similar to the action of IMiDs [388]. Clinical trials using these molecules for the treatment of solid tumors have been performed, but none of them advanced due to limited efficacy. However, it has since been suggested that the molecules be revisited for the treatment of leukemias and lymphomas due to these cells' heightened dependence on RMB39 [388].

Hydrophobic tagging is another strategy for targeted protein degradation. Fulvestrant is a therapeutic that exposes a hydrophobic patch on the surface of ER $\alpha$ and thereby mediates its degradation [389]. Inspired by this modality, hydrophobic tagging mimics a partially unfolded protein state to induce proteasomal degradation [34]. In 2014, the previously "undruggable" target Her3 was potently degraded in cells by a bivalent molecule (TX2-121-1) derived from coupling a covalent ligand to a hydrophobic adamantyl moiety [390]. Similarly, selective degradation of the AR was induced by a molecule consisting of the hydrophobic adamantyl moiety and known AR ligand RU59063 [391], adding to the cohort of existing selective androgen receptor downregulators (SARDs).

Other means have also been pursued to achieve targeted protein degradation. Chimeric proteins similar to PROTACs have been developed, in which a CHIP E3 ligase was linked to either the scFv of an antibody or a fibronectin type III domain monobody; and these molecules successfully depleted protein targets in cells [392]. However, the disulfide bonds present in the scFvs caused challenges in achieving optimal folding within the cell cytoplasm. Finally, selective degradation of proteins was achieved by using a Boc3Arg moiety linked to small-molecule inhibitors of the protein targets; the mode of action involved no ubiquitination, instead relying on direct interaction between the Boc3Arg compound and the proteasome [393].

Finally, DUBs can be recruited for targeted protein stabilization. In the first ever reported study of targeted deubiquitination, Kanner et al. developed engineered DUBs (enDUBs) to facilitate $\mathrm{Ub}$ removal and rescue of target proteins [394]. The first-in-class enDUBs consisted of the catalytic domains of OTUD1 fused to a nanobody specific for their target. In their study, the researchers used enDUBs to rescue Ub-responsive mutations in deadly ion channelopathies, long QT syndrome (LQT), and cystic fibrosis (CF), but the enDUB technology could theoretically be applied to directly stabilize protective proteins in cancers. This idea opens the door for targeted protein deubiquitination by other means, for example, in a PROTAC-like molecule that recruits a DUB instead of an E3 ligase endogenously. As further developments in the strategy of targeted deubiquitination arise, they could provide a promising new avenue for therapeutic development.

\section{Conclusions}

The UPS is a rich resource of attractive targets for developing cancer therapeutics due to its essential role in controlling protein homeostasis. In cancer cells, precision targeting 
of UPS proteins via small-molecule inhibitors has been successful in affecting disease outcomes. However, the three main strategies for modulating the UPS (inhibiting the proteasome, inhibiting the E1-E2-E3 cascade, or inhibiting DUBs) are limited due to the important and complex roles served by each of these players. Unwanted effects of global modulation of individual UPS components can limit the utility of inhibitory molecules. Furthermore, the pharmacological model of inhibition by small molecules applies only to those members with well-defined active sites and catalytic functions, greatly limiting the druggable proteome. Thus, the emerging philosophy of targeted protein degradation, exemplified by the PROTAC technology, allows more fine-tuned control of pathological targets in cancer and other diseases.

Aside from the small-molecule strategies mentioned in this review, protein-based modulators (both activators and inhibitors) of UPS members have been widely developed. As an example, clinical trials are currently ongoing for a stapled $\alpha$-helical peptide-based dual inhibitor of MDM2 and MDMX [395]. In addition, the structure-based combinatorial $\mathrm{Ub}$ variant $(\mathrm{UbV})$ protein engineering technology leverages $\mathrm{Ub}$ as a scaffold to develop synthetic binders targeting Ub-interacting proteins, including those not easily targeted by small molecules [396]. UbVs have been developed so far to potently and specifically modulate DUBs [397-399], E2 enzymes [397,400], and E3 ligases [401]. The UbV platform has proven to be a robust research tool already, and its further development may represent an exciting future avenue in precision medicine. For example, UbVs can be used to develop small-molecule modulators through displacement screens or could be incorporated into targeted protein degradation applications, such as PROTACs [401].

Improving the specificity and efficacy of therapeutics by working towards tissueand tumor-specific target degradation will improve treatment outcomes. As different approaches to screening technologies reveal new small-molecule inhibitors and ligands for targeted degradation methods, the field of precision medicine in cancer will benefit. Advancements in PROTACs, UbVs, enDUBs, and the other strategies mentioned in this review are examples of this paradigm moving closer to clinical reality.

Author Contributions: Writing — original draft preparation, G.L.; writing—review and editing, G.L., W.Z.; supervision, W.Z.; funding acquisition, W.Z. All authors have read and agreed to the published version of the manuscript.

Funding: This research was funded by a Canadian Institutes for Health Research (CIHR) Project Grant (PJT-162249) awarded to W.Z.

Acknowledgments: We apologize to the researchers whose work was not included in this review. We thank all members of the Zhang laboratory for their comments and suggestions.

Conflicts of Interest: The authors declare no conflict of interest.

\section{References}

1. Uckelmann, M.; Sixma, T.K. Histone ubiquitination in the DNA damage response. DNA Repair 2017, 56, 92-101. [CrossRef]

2. Hicke, L. Protein regulation by monoubiquitin. Nat. Rev. Mol. Cell Biol. 2001, 2, 195-201. [CrossRef]

3. Bednash, J.S.; Mallampalli, R.K. Regulation of inflammasomes by ubiquitination. Cell. Mol. Immunol. 2016, 13, 722-728. [CrossRef]

4. Leestemaker, Y.; Ovaa, H. Tools to investigate the ubiquitin proteasome system. Drug Discov. Today Technol. 2017, 26, 25-31. [CrossRef] [PubMed]

5. Mennerich, D.; Kubaichuk, K.; Kietzmann, T. DUBs, Hypoxia, and Cancer. Trends Cancer 2019, 5, 632-653. [CrossRef] [PubMed]

6. Passmore, L.A.; Barford, D. Getting into position: The catalytic mechanisms of protein ubiquitylation. Biochem. J. 2004, 379, 513-525. [CrossRef]

7. Li, W.; Ye, Y. Polyubiquitin chains: Functions, structures, and mechanisms. Cell. Mol. Life Sci. 2008, 65, 2397-2406. [CrossRef]

8. Ronai, Z.A. Monoubiquitination in proteasomal degradation. Proc. Natl. Acad. Sci. USA 2016, 113, 8894-8896. [CrossRef]

9. Nakamura, N. Ubiquitin System. Int. J. Mol. Sci. 2018, 19, 1080. [CrossRef]

10. Deng, L.; Meng, T.; Chen, L.; Wei, W.; Wang, P. The role of ubiquitination in tumorigenesis and targeted drug discovery. Signal Transduct. Target. Ther. 2020, 5, 1-28. [CrossRef] [PubMed]

11. Clague, M.J.; Urbé, S.; Komander, D. Breaking the chains: Deubiquitylating enzyme specificity begets function. Nat. Rev. Mol. Cell Biol. 2019, 20, 338-352. [CrossRef] [PubMed]

12. Adams, J. The proteasome: Structure, function, and role in the cell. Cancer Treat. Rev. 2003, 29, 3-9. [CrossRef] 
13. Mofers, A.; Pellegrini, P.; Linder, S.; D’Arcy, P. Proteasome-associated deubiquitinases and cancer. Cancer Metastasis Rev. 2017, 36, 635-653. [CrossRef] [PubMed]

14. Lauwers, E.; Jacob, C.; André, B. K63-linked ubiquitin chains as a specific signal for protein sorting into the multivesicular body pathway. J. Cell Biol. 2009, 185, 493-502. [CrossRef]

15. Tracz, M.; Bialek, W. Beyond K48 and K63: Non-canonical protein ubiquitination. Cell. Mol. Biol. Lett. 2021, 26, 1-17. [CrossRef]

16. Hicke, L.; Schubert, H.L.; Hill, C.P. Ubiquitin-binding domains. Nat. Rev. Mol. Cell Biol. 2005, 6, 610-621. [CrossRef] [PubMed]

17. Zhang, X.; Linder, S.; Bazzaro, M. Drug Development Targeting the Ubiquitin-Proteasome System (UPS) for the Treatment of Human Cancers. Cancers 2020, 12, 902. [CrossRef] [PubMed]

18. Lin, H.; Li, S.; Shu, H.-B. The Membrane-Associated MARCH E3 Ligase Family: Emerging Roles in Immune Regulation. Front. Immunol. 2019, 10, 1751. [CrossRef]

19. Nijman, S.M.; Luna-Vargas, M.P.; Velds, A.; Brummelkamp, T.R.; Dirac, A.M.; Sixma, T.K.; Bernards, R. A Genomic and Functional Inventory of Deubiquitinating Enzymes. Cell 2005, 123, 773-786. [CrossRef]

20. Komander, D.; Clague, M.; Urbé, S. Breaking the chains: Structure and function of the deubiquitinases. Nat. Rev. Mol. Cell Biol. 2009, 10, 550-563. [CrossRef]

21. Fraile, J.M.; Quesada, V.; Rodríguez, D.; Freije, J.M.; Otín, C.L. Deubiquitinases in cancer: New functions and therapeutic options. Oncogene 2012, 31, 2373-2388. [CrossRef]

22. Coleman, K.E.; Huang, T.T. In a Class of Its Own: A New Family of Deubiquitinases Promotes Genome Stability. Mol. Cell 2018, 70, 1-3. [CrossRef] [PubMed]

23. Gallo, L.H.; Ko, J.; Donoghue, D.J. The importance of regulatory ubiquitination in cancer and metastasis. Cell Cycle 2017, 16, 634-648. [CrossRef]

24. Nakayama, K.I.; Nakayama, K. Ubiquitin ligases: Cell-cycle control and cancer. Nat. Rev. Cancer 2006, 6, 369-381. [CrossRef]

25. Mao, J.-H.; Kim, I.-J.; Wu, D.; Climent, J.; Kang, H.C.; DelRosario, R.; Balmain, A. FBXW7 Targets mTOR for Degradation and Cooperates with PTEN in Tumor Suppression. Science 2008, 321, 1499-1502. [CrossRef] [PubMed]

26. Karbowski, M.; Youle, R.J. Regulating mitochondrial outer membrane proteins by ubiquitination and proteasomal degradation. Curr. Opin. Cell Biol. 2011, 23, 476-482. [CrossRef]

27. Nakamura, N.; Kimura, Y.; Tokuda, M.; Honda, S.; Hirose, S. MARCH-V is a novel mitofusin 2- and Drp1-binding protein able to change mitochondrial morphology. EMBO Rep. 2006, 7, 1019-1022. [CrossRef] [PubMed]

28. Lavie, J.; De Belvalet, H.; Sonon, S.; Ion, A.M.; Dumon, E.; Melser, S.; Lacombe, D.; Dupuy, J.-W.; Lalou, C.; Bénard, G. UbiquitinDependent Degradation of Mitochondrial Proteins Regulates Energy Metabolism. Cell Rep. 2018, 23, 2852-2863. [CrossRef] [PubMed]

29. Aiken, C.T.; Kaake, R.M.; Wang, X.; Huang, L. Oxidative Stress-Mediated Regulation of Proteasome Complexes. Mol. Cell. Proteom. 2011, 10, R110-006924. [CrossRef] [PubMed]

30. O'Donnell, M.A.; Legarda-Addison, D.; Skountzos, P.; Yeh, W.C.; Ting, A.T. Ubiquitination of RIP1 Regulates an NF-kBIndependent Cell-Death Switch in TNF Signaling. Curr. Biol. 2007, 17, 418-424. [CrossRef]

31. Bazzaro, M.; Lee, M.K.; Zoso, A.; Stirling, W.L.; Santillan, A.; Shih, I.-M.; Roden, R.B. Ubiquitin-Proteasome System Stress Sensitizes Ovarian Cancer to Proteasome Inhibitor-Induced Apoptosis. Cancer Res. 2006, 66, 3754-3763. [CrossRef] [PubMed]

32. Richardson, P.G.; Hideshima, T.; Anderson, K.C. Bortezomib (PS-341): A Novel, First-in-Class Proteasome Inhibitor for the Treatment of Multiple Myeloma and Other Cancers. Cancer Control 2003, 10, 361-369. [CrossRef] [PubMed]

33. Veggiani, G.; Gerpe, M.C.R.; Sidhu, S.S.; Zhang, W. Emerging drug development technologies targeting ubiquitination for cancer therapeutics. Pharmacol. Ther. 2019, 199, 139-154. [CrossRef]

34. Bondeson, D.P.; Crews, C.M. Targeted Protein Degradation by Small Molecules. Annu. Rev. Pharmacol. Toxicol. 2017, 57, 107-123. [CrossRef]

35. Hoeller, D.; Dikic, I. Targeting the ubiquitin system in cancer therapy. Nat. Cell Biol. 2009, 458, 438-444. [CrossRef] [PubMed]

36. O'Connor, O.A.; Stewart, A.K.; Vallone, M.; Molineaux, C.J.; Kunkel, L.A.; Gerecitano, J.F.; Orlowski, R. A Phase 1 Dose Escalation Study of the Safety and Pharmacokinetics of the Novel Proteasome Inhibitor Carfilzomib (PR-171) in Patients with Hematologic Malignancies. Clin. Cancer Res. 2009, 15, 7085-7091. [CrossRef]

37. Demo, S.D.; Kirk, C.J.; Aujay, M.A.; Buchholz, T.J.; Dajee, M.; Ho, M.N.; Jiang, J.; Laidig, G.J.; Lewis, E.R.; Parlati, F.; et al. Antitumor Activity of PR-171, a Novel Irreversible Inhibitor of the Proteasome. Cancer Res. 2007, 67, 6383-6391. [CrossRef]

38. Rajan, A.M.; Kumar, S. New investigational drugs with single-agent activity in multiple myeloma. Blood Cancer J. 2016, 6, e451. [CrossRef]

39. Richardson, P.G.; Baz, R.; Wang, M.; Jakubowiak, A.J.; Laubach, J.P.; Harvey, R.D.; Talpaz, M.; Berg, D.; Liu, G.; Yu, J.; et al. Phase 1 study of twice-weekly ixazomib, an oral proteasome inhibitor, in relapsed/refractory multiple myeloma patients. Blood 2014, 124, 1038-1046. [CrossRef] [PubMed]

40. Lee, B.-H.; Lee, M.J.; Park, S.; Oh, D.-C.; Elsasser, S.; Chen, P.-C.; Gartner, C.; Dimova, N.; Hanna, J.; Gygi, S.P.; et al. Enhancement of proteasome activity by a small-molecule inhibitor of USP. Nat. Cell Biol. 2010, 467, 179-184. [CrossRef]

41. D’Arcy, P.; Brnjic, S.; Olofsson, M.H.; Fryknäs, M.; Lindsten, K.; De Cesare, M.; Perego, P.; Sadeghi, B.; Hassan, M.; Larsson, R.; et al. Inhibition of proteasome deubiquitinating activity as a new cancer therapy. Nat. Med. 2011, 17, 1636-1640. [CrossRef] 
42. Wang, X.; Mazurkiewicz, M.; Hillert, E.-K.; Olofsson, M.H.; Pierrou, S.; Hillertz, P.; Gullbo, J.; Selvaraju, K.; Paulus, A.; Akhtar, S.; et al. The proteasome deubiquitinase inhibitor VLX1570 shows selectivity for ubiquitin-specific protease-14 and induces apoptosis of multiple myeloma cells. Sci. Rep. 2016, 6, 26979. [CrossRef]

43. Coughlin, K.; Anchoori, R.; Iizuka, Y.; Meints, J.; MacNeill, L.; Vogel, R.; Orlowski, R.; Lee, M.K.; Roden, R.B.; Bazzaro, M. Small-Molecule RA-9 Inhibits Proteasome-Associated DUBs and Ovarian Cancer In Vitro and In Vivo via Exacerbating Unfolded Protein Responses. Clin. Cancer Res. 2014, 20, 3174-3186. [CrossRef] [PubMed]

44. Kapuria, V.; Peterson, L.F.; Fang, D.; Bornmann, W.G.; Talpaz, M.; Donato, N.J. Deubiquitinase Inhibition by Small-Molecule WP1130 Triggers Aggresome Formation and Tumor Cell Apoptosis. Cancer Res. 2010, 70, 9265-9276. [CrossRef] [PubMed]

45. Anchoori, R.K.; Karanam, B.; Peng, S.; Wang, J.W.; Jiang, R.; Tanno, T.; Orlowski, R.; Matsui, W.; Zhao, M.; Rudek, M.A.; et al. A bis-Benzylidine Piperidone Targeting Proteasome Ubiquitin Receptor RPN13/ADRM1 as a Therapy for Cancer. Cancer Cell 2013, 24, 791-805. [CrossRef] [PubMed]

46. Karin, M.; Cao, Y.; Greten, F.; Li, Z.-W. NF-кB in cancer: From innocent bystander to major culprit. Nat. Rev. Cancer 2002, 2, 301-310. [CrossRef] [PubMed]

47. Hideshima, T.; Chauhan, D.; Richardson, P.; Mitsiades, C.; Mitsiades, N.; Hayashi, T.; Munshi, N.; Dang, L.; Castro, A.; Palombella, V.; et al. NF-kB as a Therapeutic Target in Multiple Myeloma. J. Biol. Chem. 2002, 277, 16639-16647. [CrossRef]

48. Richardson, P.G.; Sonneveld, P.; Schuster, M.; Irwin, D.; Stadtmauer, E.; Facon, T.; Harousseau, J.-L.; Ben-Yehuda, D.; Lonial, S.; Goldschmidt, H.; et al. Bortezomib or High-Dose Dexamethasone for Relapsed Multiple Myeloma. N. Engl. J. Med. 2005, 352, 2487-2498. [CrossRef]

49. Sunwoo, J.B.; Chen, Z.; Dong, G.; Yeh, N.; Bancroft, C.C.; Sausville, E.; Adams, J.; Elliott, P.; Van Waes, C. Novel proteasome inhibitor PS-341 inhibits activation of nuclear factor $-\mathrm{kB}$, cell survival, tumor growth, and angiogenesis in squamous cell carcinoma. Clin. Cancer Res. 2001, 7, 1419-1428.

50. Hideshima, T.; Richardson, P.; Chauhan, D.; Palombella, V.J.; Elliott, P.J.; Adams, J.; Anderson, K.C. The proteasome inhibitor PS-341 inhibits growth, induces apoptosis, and overcomes drug resistance in human multiple myeloma cells. Cancer Res. 2001, 61, 3071-3076.

51. Baiz, D.; Pozzato, G.; Dapas, B.; Farra, R.; Scaggiante, B.; Grassi, M.; Uxa, L.; Giansante, C.; Zennaro, C.; Guarnieri, G.; et al. Bortezomib arrests the proliferation of hepatocellular carcinoma cells HepG2 and JHH6 by differentially affecting E2F1, p21 and p27 levels. Biochimie 2009, 91, 373-382. [CrossRef] [PubMed]

52. Kontopodis, E.; Kotsakis, A.; Kentepozidis, N.; Syrigos, K.; Ziras, N.; Moutsos, M.; Filippa, G.; Mala, A.; Vamvakas, L.; Mavroudis, D.; et al. A phase II, open-label trial of bortezomib (VELCADE®) in combination with gemcitabine and cisplatin in patients with locally advanced or metastatic non-small cell lung cancer. Cancer Chemother. Pharmacol. 2016, 77, 949-956. [CrossRef]

53. Fisher, R.I.; Bernstein, S.H.; Kahl, B.S.; Djulbegovic, B.; Robertson, M.J.; De Vos, S.; Epner, E.; Krishnan, A.; Leonard, J.P.; Lonial, S.; et al. Multicenter Phase II Study of Bortezomib in Patients with Relapsed or Refractory Mantle Cell Lymphoma. J. Clin. Oncol. 2006, 24, 4867-4874. [CrossRef]

54. Cavaletti, G.; Jakubowiak, A.J. Peripheral neuropathy during bortezomib treatment of multiple myeloma: A review of recent studies. Leuk. Lymphoma 2010, 51, 1178-1187. [CrossRef]

55. Shin, Y.K.; Jang, S.Y.; Lee, H.K.; Jung, J.; Suh, D.J.; Seo, S.-Y.; Park, H.T. Pathological adaptive responses of Schwann cells to endoplasmic reticulum stress in bortezomib-induced peripheral neuropathy. Glia 2010, 58, 1961-1976. [CrossRef]

56. Suzuki, E.; Demo, S.; Deu, E.; Keats, J.; Arastu-Kapur, S.; Bergsagel, P.L.; Bennett, M.K.; Kirk, C.J. Molecular Mechanisms of Bortezomib Resistant Adenocarcinoma Cells. PLoS ONE 2011, 6, e27996. [CrossRef] [PubMed]

57. Oerlemans, R.; Franke, N.E.; Assaraf, Y.G.; Cloos, J.; Van Zantwijk, I.; Berkers, C.R.; Scheffer, G.L.; Debipersad, K.; Vojtekova, K.; Lemos, C.; et al. Molecular basis of bortezomib resistance: Proteasome subunit $\beta 5$ (PSMB5) gene mutation and overexpression of PSMB5 protein. Blood 2008, 112, 2489-2499. [CrossRef]

58. Wu, H.Q.; Baker, D.; Ovaa, H. Small molecules that target the ubiquitin system. Biochem. Soc. Trans. 2020, 48, 479-497. [CrossRef]

59. Girnius, S.K.; Lee, S.; Kambhampati, S.; Rose, M.G.; Mohiuddin, A.; Houranieh, A.; Zimelman, A.; Grady, T.; Mehta, P.; Behler, C.; et al. A Phase II trial of weekly bortezomib and dexamethasone in veterans with newly diagnosed multiple myeloma not eligible for or who deferred autologous stem cell transplantation. Br. J. Haematol. 2015, 169, 36-43. [CrossRef] [PubMed]

60. Straka, C.; Knop, S.; Vogel, M.; Müller, J.; Kropff, M.; Metzner, B.; Langer, C.; Sayer, H.; Jung, W.; Dürk, H.A.; et al. Bortezomib consolidation following autologous transplant in younger and older patients with newly diagnosed multiple myeloma in two phase III trials. Eur. J. Haematol. 2019, 103, 255-267. [CrossRef]

61. Moreau, P.; Pylypenko, H.; Grosicki, S.; Karamanesht, I.; Leleu, X.; Grishunina, M.; Rekhtman, G.; Masliak, Z.; Robak, T.; Shubina, A.; et al. Subcutaneous versus intravenous administration of bortezomib in patients with relapsed multiple myeloma: A randomised, phase 3, non-inferiority study. Lancet Oncol. 2011, 12, 431-440. [CrossRef]

62. Berenson, J.R.; Hilger, J.D.; Yellin, O.; Dichmann, R.; Pateldonnelly, D.; Boccia, R.V.; Bessudo, A.; Stampleman, L.; Gravenor, D.S.; Eshaghian, S.; et al. Replacement of bortezomib with carfilzomib for multiple myeloma patients progressing from bortezomib combination therapy. Leukemia 2014, 28, 1529-1536. [CrossRef] [PubMed]

63. Moreau, P.; Joshua, D.; Chng, W.-J.; Palumbo, A.; Goldschmidt, H.; Hajek, R.; Facon, T.; Ludwig, H.; Pour, L.; Niesvizky, R.; et al. Impact of prior treatment on patients with relapsed multiple myeloma treated with carfilzomib and dexamethasone vs bortezomib and dexamethasone in the phase 3 ENDEAVOR study. Leukemia 2016, 31, 115-122. [CrossRef] 
64. Berdeja, J.G.; Gregory, T.K.; Faber, E.A.; Hart, L.L.; Mace, J.R.; Arrowsmith, E.R.; Flinn, I.W.; Matous, J.V. A phase I/II study of the combination of panobinostat and carfilzomib in patients with relapsed or relapsed/refractory multiple myeloma: Final analysis of second dose-expansion cohort. Am. J. Hematol. 2021, 96, 428-435. [CrossRef] [PubMed]

65. Chauhan, D.; Singh, A.V.; Aujay, M.; Kirk, C.J.; Bandi, M.; Ciccarelli, B.; Raje, N.; Richardson, P.; Anderson, K.C. A novel orally active proteasome inhibitor ONX 0912 triggers in vitro and in vivo cytotoxicity in multiple myeloma. Blood 2010, 116, 4906-4915. [CrossRef] [PubMed]

66. Hari, P.; Paba-Prada, C.E.; Voorhees, P.M.; Frye, J.; Chang, Y.-L.; Moreau, P.; Zonder, J.; Boccia, R.; Shain, K.H. Efficacy and safety results from a phase $1 \mathrm{~b} / 2$, multicenter, open-label study of oprozomib and dexamethasone in patients with relapsed and/or refractory multiple myeloma. Leuk. Res. 2019, 83, 106172. [CrossRef]

67. Kupperman, E.; Lee, E.C.; Cao, Y.; Bannerman, B.; Fitzgerald, M.; Berger, A.; Yu, J.; Yang, Y.; Hales, P.; Bruzzese, F.; et al. Evaluation of the Proteasome Inhibitor MLN9708 in Preclinical Models of Human Cancer. Cancer Res. 2010, 70, 1970-1980. [CrossRef] [PubMed]

68. Chauhan, D.; Tian, Z.; Zhou, B.; Kuhn, D.; Orlowski, R.; Raje, N.; Richardson, P.; Anderson, K.C. In Vitro and In Vivo Selective Antitumor Activity of a Novel Orally Bioavailable Proteasome Inhibitor MLN9708 against Multiple Myeloma Cells. Clin. Cancer Res. 2011, 17, 5311-5321. [CrossRef] [PubMed]

69. Lee, E.C.; Fitzgerald, M.; Bannerman, B.; Donelan, J.; Bano, K.; Terkelsen, J.; Bradley, D.P.; Subakan, O.; Silva, M.D.; Liu, R.; et al. Antitumor Activity of the Investigational Proteasome Inhibitor MLN9708 in Mouse Models of B-cell and Plasma Cell Malignancies. Clin. Cancer Res. 2011, 17, 7313-7323. [CrossRef]

70. Ludwig, H.; Poenisch, W.; Knop, S.; Egle, A.; Schreder, M.; Lechner, D.; Hajek, R.; Gunsilius, E.; Krenosz, K.J.; Petzer, A.; et al. Ixazomib-Thalidomide-Dexamethasone for induction therapy followed by Ixazomib maintenance treatment in patients with relapsed/refractory multiple myeloma. Br. J. Cancer 2019, 121, 751-757. [CrossRef]

71. Gupta, N.; Yang, H.; Hanley, M.J.; Zhang, S.; Liu, R.; Kumar, S.; Richardson, P.G.; Skacel, T.; Venkatakrishnan, K. Dose and Schedule Selection of the Oral Proteasome Inhibitor Ixazomib in Relapsed/Refractory Multiple Myeloma: Clinical and Model-Based Analyses. Target. Oncol. 2017, 12, 643-654. [CrossRef]

72. Wang, Y.; Jiang, Y.; Ding, S.; Li, J.; Song, N.; Ren, Y.; Hong, D.; Wu, C.; Li, B.; Wang, F.; et al. Small molecule inhibitors reveal allosteric regulation of USP14 via steric blockade. Cell Res. 2018, 28, 1186-1194. [CrossRef]

73. Tian, Z.; D'Arcy, P.; Wang, X.; Ray, A.; Tai, Y.-T.; Hu, Y.; Carrasco, R.D.; Richardson, P.; Linder, S.; Chauhan, D.; et al. A novel small molecule inhibitor of deubiquitylating enzyme USP14 and UCHL5 induces apoptosis in multiple myeloma and overcomes bortezomib resistance. Blood 2014, 123, 706-716. [CrossRef]

74. Zhang, X.; Pellegrini, P.; Saei, A.A.; Hillert, E.-K.; Mazurkiewicz, M.; Olofsson, M.H.; Zubarev, R.; D'Arcy, P.; Linder, S. The deubiquitinase inhibitor b-AP15 induces strong proteotoxic stress and mitochondrial damage. Biochem. Pharmacol. 2018, 156, 291-301. [CrossRef] [PubMed]

75. Sun, H.; Kapuria, V.; Peterson, L.F.; Fang, D.; Bornmann, W.G.; Bartholomeusz, G.; Talpaz, M.; Donato, N.J. Bcr-Abl ubiquitination and Usp9x inhibition block kinase signaling and promote CML cell apoptosis. Blood 2011, 117, 3151-3162. [CrossRef]

76. Potu, H.; Kandarpa, M.; Peterson, L.F.; Durham, A.; Donato, N.J.; Talpaz, M. Downregulation of SOX2 by inhibition of Usp9X induces apoptosis in melanoma. Oncotarget 2021, 12, 160-172. [CrossRef] [PubMed]

77. Pham, L.V.; Tamayo, A.T.; Li, C.; Bornmann, W.; Priebe, W.; Ford, R.J. Degrasyn Potentiates the Antitumor Effects of Bortezomib in Mantle Cell Lymphoma Cells In vitro and In vivo: Therapeutic Implications. Mol. Cancer Ther. 2010, 9, 2026-2036. [CrossRef]

78. Akiyama, H.; Umezawa, Y.; Ishida, S.; Okada, K.; Nogami, A.; Miura, O. Inhibition of USP9X induces apoptosis in FLT3-ITDpositive AML cells cooperatively by inhibiting the mutant kinase through aggresomal translocation and inducing oxidative stress. Cancer Lett. 2019, 453, 84-94. [CrossRef]

79. Li, J.; Yakushi, T.; Parlati, F.; MacKinnon, A.L.; Perez, C.; Ma, Y.; Carter, K.P.; Colayco, S.; Magnuson, G.; Brown, B.; et al. Capzimin is a potent and specific inhibitor of proteasome isopeptidase Rpn. Nat. Chem. Biol. 2017, 13, 486-493. [CrossRef]

80. Li, J.; Zhang, Y.; Santos, B.D.S.S.D.; Wang, F.; Ma, Y.; Perez, C.; Yang, Y.; Peng, J.; Cohen, S.M.; Chou, T.-F.; et al. Epidithiodiketopiperazines Inhibit Protein Degradation by Targeting Proteasome Deubiquitinase Rpn. Cell Chem. Biol. 2018, 25, 1350-1358.e9. [CrossRef] [PubMed]

81. Soucy, T.A.; Smith, P.G.; Milhollen, M.A.; Berger, A.J.; Gavin, J.M.; Adhikari, S.; Brownell, J.E.; Burke, K.E.; Cardin, D.P.; Critchley, S.; et al. An inhibitor of NEDD8-activating enzyme as a new approach to treat cancer. Nat. Cell Biol. 2009, 458, 732-736. [CrossRef]

82. Milhollen, M.A.; Traore, T.; Adams-Duffy, J.; Thomas, M.P.; Berger, A.J.; Dang, L.; Dick, L.R.; Garnsey, J.J.; Koenig, E.; Langston, S.P.; et al. MLN4924, a NEDD8-activating enzyme inhibitor, is active in diffuse large B-cell lymphoma models: Rationale for treatment of NF-kB-dependent lymphoma. Blood 2010, 116, 1515-1523. [CrossRef] [PubMed]

83. Swords, R.T.; Kelly, K.R.; Smith, P.G.; Garnsey, J.J.; Mahalingam, D.; Medina, E.; Oberheu, K.; Padmanabhan, S.; Dwyer, M.O.; Nawrocki, S.T.; et al. Brief report Inhibition of NEDD8-activating enzyme: A novel approach for the treatment of acute myeloid leukemia. Blood 2010, 115, 3796-3800. [CrossRef] [PubMed]

84. Zhou, X.; Sedarati, F.; Faller, D.V.; Zhao, D.; Faessel, H.M.; Chowdhury, S.; Bolleddula, J.; Li, Y.; Venkatakrishnan, K.; Papai, Z. Phase I study assessing the mass balance, pharmacokinetics, and excretion of $\left[{ }^{14} \mathrm{C}\right]$-pevonedistat, a NEDD8-activating enzyme inhibitor in patients with advanced solid tumors. Investig. New Drugs 2021, 39, 488-498. [CrossRef] 
85. Faessel, H.M.; Mould, D.R.; Zhou, X.; Faller, U.V.; Sedarati, F.; Venkatakrishnan, K. Population pharmacokinetics of pevonedistat alone or in combination with standard of care in patients with solid tumours or haematological malignancies. Br. J. Clin. Pharmacol. 2019, 85, 2568-2579. [CrossRef] [PubMed]

86. Lockhart, A.C.; Bauer, T.M.; Aggarwal, C.; Lee, C.B.; Harvey, R.D.; Cohen, R.B.; Sedarati, F.; Nip, T.K.; Faessel, H.; Dash, A.B.; et al. Phase Ib study of pevonedistat, a NEDD8-activating enzyme inhibitor, in combination with docetaxel, carboplatin and paclitaxel, or gemcitabine, in patients with advanced solid tumors. Investig. New Drugs 2019, 37, 87-97. [CrossRef]

87. Swords, R.T.; Coutre, S.; Maris, M.B.; Zeidner, J.F.; Foran, J.M.; Cruz, J.; Erba, H.P.; Berdeja, J.G.; Tam, W.; Vardhanabhuti, S.; et al. Pevonedistat, a first-in-class NEDD8-activating enzyme inhibitor, combined with azacitidine in patients with AML. Blood 2018, 131, 1415-1424. [CrossRef]

88. Ceccarelli, D.; Tang, X.; Pelletier, B.; Orlicky, S.; Xie, W.; Plantevin, V.; Neculai, D.; Chou, Y.-C.; Ogunjimi, A.; Al-Hakim, A.; et al. An Allosteric Inhibitor of the Human Cdc34 Ubiquitin-Conjugating Enzyme. Cell 2011, 145, 1075-1087. [CrossRef]

89. Pulvino, M.; Liang, Y.; Oleksyn, D.; DeRan, M.; Van Pelt, E.; Shapiro, J.; Sanz, I.; Chen, L.; Zhao, J. Inhibition of proliferation and survival of diffuse large B-cell lymphoma cells by a small-molecule inhibitor of the ubiquitin-conjugating enzyme Ubc13-Uev1A. Blood 2012, 120, 1668-1677. [CrossRef]

90. Yang, Y.; Kitagaki, J.; Dai, R.-M.; Tsai, Y.C.; Lorick, K.L.; Ludwig, R.L.; Pierre, S.A.; Jensen, J.P.; Davydov, I.V.; Oberoi, P.; et al. Inhibitors of Ubiquitin-Activating Enzyme (E1), a New Class of Potential Cancer Therapeutics. Cancer Res. 2007, 67, 9472-9481. [CrossRef]

91. You, X.; Xu, D.D.; Zhang, D.; Chen, J.; Gao, F.G. PYR-41 and Thalidomide Impair Dendritic Cell Cross-Presentation by Inhibiting Myddosome Formation and Attenuating the Endosomal Recruitments of p97 and Sec61 via NF-кB Inactivation. J. Immunol. Res. 2018, 2018, 1-14. [CrossRef] [PubMed]

92. Micel, L.N.; Tentler, J.J.; Smith, P.G.; Eckhardt, G.S. Role of Ubiquitin Ligases and the Proteasome in Oncogenesis: Novel Targets for Anticancer Therapies. J. Clin. Oncol. 2013, 31, 1231-1238. [CrossRef]

93. Sarantopoulos, J.; Shapiro, G.I.; Cohen, R.B.; Clark, J.W.; Kauh, J.S.; Weiss, G.J.; Cleary, J.M.; Mahalingam, D.; Pickard, M.D.; Faessel, H.M.; et al. Phase I Study of the Investigational NEDD8-Activating Enzyme Inhibitor Pevonedistat (TAK-924/MLN4924) in Patients with Advanced Solid Tumors. Clin. Cancer Res. 2016, 22, 847-857. [CrossRef]

94. Lovering, R.; Hanson, I.M.; Borden, K.L.; Martin, S.; O’Reilly, N.; Evan, G.I.; Rahman, D.; Pappin, D.; Trowsdale, J.; Freemont, P. Identification and preliminary characterization of a protein motif related to the zinc finger. Proc. Natl. Acad. Sci. USA 1993, 90, 2112-2116. [CrossRef] [PubMed]

95. Metzger, M.B.; Pruneda, J.; Klevit, R.E.; Weissman, A.M. RING-type E3 ligases: Master manipulators of E2 ubiquitin-conjugating enzymes and ubiquitination. Biochim. Biophys. Acta Bioenerg. 2014, 1843, 47-60. [CrossRef]

96. Lee, J.; Zhou, P. DCAFs, the Missing Link of the CUL4-DDB1 Ubiquitin Ligase. Mol. Cell 2007, 26, 775-780. [CrossRef]

97. Schreiber, A.; Stengel, F.; Zhang, Z.; Enchev, R.I.; Kong, E.H.; Morris, E.; Robinson, C.V.; Da Fonseca, P.C.A.; Barford, D. Structural basis for the subunit assembly of the anaphase-promoting complex. Nat. Cell Biol. 2011, 470, 227-232. [CrossRef] [PubMed]

98. Berndsen, C.; Wolberger, C. New insights into ubiquitin E3 ligase mechanism. Nat. Struct. Mol. Biol. 2014, 21, 301-307. [CrossRef]

99. Rotin, D.; Kumar, S. Physiological functions of the HECT family of ubiquitin ligases. Nat. Rev. Mol. Cell Biol. 2009, 10, 398-409. [CrossRef]

100. Wang, Y.; Argiles-Castillo, D.; Kane, E.I.; Zhou, A.; Spratt, D.E. Erratum: HECT E3 ubiquitin ligases-Emerging insights into their biological roles and disease relevance. J. Cell Sci. 2020, 133. [CrossRef]

101. Kojima, K.; Konopleva, M.; Samudio, I.J.; Shikami, M.; Cabreira-Hansen, M.; McQueen, T.; Ruvolo, V.; Tsao, T.; Zeng, Z.; Vassilev, L.T.; et al. MDM2 antagonists induce p53-dependent apoptosis in AML: Implications for leukemia therapy. Blood 2005, 106, 3150-3159. [CrossRef] [PubMed]

102. Secchiero, P.; Barbarotto, E.; Tiribelli, M.; Zerbinati, C.; Di Iasio, M.G.; Gonelli, A.; Cavazzini, F.; Campioni, D.; Fanin, R.; Cuneo, A.; et al. Functional integrity of the p53-mediated apoptotic pathway induced by the nongenotoxic agent nutlin-3 in B-cell chronic lymphocytic leukemia (B-CLL). Blood 2006, 107, 4122-4129. [CrossRef] [PubMed]

103. Secchiero, P.; Melloni, E.; Di Iasio, M.G.; Tiribelli, M.; Rimondi, E.; Corallini, F.; Gattei, V.; Zauli, G. Nutlin-3 up-regulates the expression of Notch1 in both myeloid and lymphoid leukemic cells, as part of a negative feedback antiapoptotic mechanism. Blood 2009, 113, 4300-4308. [CrossRef] [PubMed]

104. Gu, L.; Zhu, N.; Findley, H.W.; Zhou, M. MDM2 antagonist nutlin-3 is a potent inducer of apoptosis in pediatric acute lymphoblastic leukemia cells with wild-type p53 and overexpression of MDM. Leukemia 2008, 22, 730-739. [CrossRef]

105. Kaindl, U.; Morak, M.; Portsmouth, C.; Mecklenbräuker, A.; Kauer, M.; Zeginigg, M.; Attarbaschi, A.; Haas, O.A.; PanzerGrümayer, R. Blocking ETV6/RUNX1-induced MDM2 overexpression by Nutlin-3 reactivates p53 signaling in childhood leukemia. Leukemia 2013, 28, 600-608. [CrossRef]

106. Tonsing-Carter, A.; Bailey, B.J.; Saadatzadeh, M.R.; Ding, J.; Wang, H.; Sinn, A.L.; Peterman, K.M.; Spragins, T.K.; Silver, J.M.; Sprouse, A.A.; et al. Potentiation of Carboplatin-Mediated DNA Damage by the Mdm2 Modulator Nutlin-3a in a Humanized Orthotopic Breast-to-Lung Metastatic Model. Mol. Cancer Ther. 2015, 14, 2850-2863. [CrossRef]

107. Tosoni, D.; Pambianco, S.; Soppo, B.E.; Zecchini, S.; Bertalot, G.; Pruneri, G.; Viale, G.; Di Fiore, P.P.; Pece, S. Pre-clinical validation of a selective anti-cancer stem cell therapy for Numb-deficient human breast cancers. EMBO Mol. Med. 2017, 9, 655-671. [CrossRef] 
108. Sarisozen, C.; Tan, Y.; Liu, J.; Bilir, C.; Shen, L.; Filipczak, N.; Porter, T.M.; Torchilin, V.P. MDM2 antagonist-loaded targeted micelles in combination with doxorubicin: Effective synergism against human glioblastoma via p53 re-activation. J. Drug Target. 2019, 27, 624-633. [CrossRef]

109. Vu, B.; Wovkulich, P.; Pizzolato, G.; Lovey, A.; Ding, Q.; Jiang, N.; Liu, J.-J.; Zhao, C.; Glenn, K.; Wen, Y.; et al. Discovery of RG7112: A Small-Molecule MDM2 Inhibitor in Clinical Development. ACS Med. Chem. Lett. 2013, 4, 466-469. [CrossRef] [PubMed]

110. Patnaik, A.; Tolcher, A.; Beeram, M.; Nemunaitis, J.; Weiss, G.J.; Bhalla, K.; Agrawal, M.; Nichols, G.; Middleton, S.; Beryozkina, A.; et al. Clinical pharmacology characterization of RG7112, an MDM2 antagonist, in patients with advanced solid tumors. Cancer Chemother. Pharmacol. 2015, 76, 587-595. [CrossRef]

111. Ray-Coquard, I.; Blay, J.-Y.; Italiano, A.; Le Cesne, A.; Penel, N.; Zhi, J.; Heil, F.; Rueger, R.; Graves, B.; Ding, M.; et al. Effect of the MDM2 antagonist RG7112 on the P53 pathway in patients with MDM2-amplified, well-differentiated or dedifferentiated liposarcoma: An exploratory proof-of-mechanism study. Lancet Oncol. 2012, 13, 1133-1140. [CrossRef]

112. Andreeff, M.; Kelly, K.R.; Yee, K.W.; Assouline, S.; Strair, R.K.; Popplewell, L.; Bowen, D.; Martinelli, G.; Drummond, M.W.; Vyas, P.; et al. Results of the Phase I Trial of RG7112, a Small-Molecule MDM2 Antagonist in Leukemia. Clin. Cancer Res. 2016, 22, 868-876. [CrossRef] [PubMed]

113. Ding, Q.; Zhang, Z.; Liu, J.-J.; Jiang, N.; Zhang, J.; Ross, T.M.; Chu, X.-J.; Bartkovitz, D.; Podlaski, F.; Janson, C.; et al. Discovery of RG7388, a Potent and Selective p53-MDM2 Inhibitor in Clinical Development. J. Med. Chem. 2013, 56, 5979-5983. [CrossRef] [PubMed]

114. Mascarenhas, J.; Lu, M.; Kosiorek, H.; Virtgaym, E.; Xia, L.; Sandy, L.; Mesa, R.; Petersen, B.; Farnoud, N.; Najfeld, V.; et al. Oral idasanutlin in patients with polycythemia vera. Blood 2019, 134, 525-533. [CrossRef] [PubMed]

115. Yee, K.; Papayannidis, C.; Vey, N.; Dickinson, M.J.; Kelly, K.R.; Assouline, S.; Kasner, M.; Seiter, K.; Drummond, M.W.; Yoon, S.-S.; et al. Murine double minute 2 inhibition alone or with cytarabine in acute myeloid leukemia: Results from an idasanutlin phase 1/1b study*. Leuk. Res. 2021, 100, 106489. [CrossRef] [PubMed]

116. Montesinos, P.; Beckermann, B.M.; Catalani, O.; Esteve, J.; Gamel, K.; Konopleva, M.Y.; Martinelli, G.; Monnet, A.; Papayannidis, C.; Park, A.; et al. MIRROS: A randomized, placebo-controlled, Phase III trial of cytarabine \pm idasanutlin in relapsed or refractory acute myeloid leukemia. Futur. Oncol. 2020, 16, 807-815. [CrossRef]

117. Wang, S.; Sun, W.; Zhao, Y.; McEachern, D.; Meaux, I.; Barrière, C.; Stuckey, J.A.; Meagher, J.L.; Bai, L.; Liu, L.; et al. SAR405838: An Optimized Inhibitor of MDM2-p53 Interaction That Induces Complete and Durable Tumor Regression. Cancer Res. 2014, 74, 5855-5865. [CrossRef] [PubMed]

118. De Jonge, M.; de Weger, V.A.; Dickson, M.A.; Langenberg, M.; Le Cesne, A.; Wagner, A.J.; Hsu, K.; Zheng, W.; Macé, S.; Tuffal, G.; et al. A phase I study of SAR405838, a novel human double minute 2 (HDM2) antagonist, in patients with solid tumours. Eur. J. Cancer 2017, 76, 144-151. [CrossRef]

119. De Weger, V.A.; De Jonge, M.; Langenberg, M.H.G.; Schellens, J.H.M.; Lolkema, M.; Varga, A.; Demers, B.; Thomas, K.; Hsu, K.; Tuffal, G.; et al. A phase I study of the HDM2 antagonist SAR405838 combined with the MEK inhibitor pimasertib in patients with advanced solid tumours. Br. J. Cancer 2019, 120, 286-293. [CrossRef]

120. Ravandi, F.; Gojo, I.; Patnaik, M.M.; Minden, M.D.; Kantarjian, H.; Johnson-Levonas, A.O.; Fancourt, C.; Lam, R.; Jones, M.B.; Knox, C.D.; et al. A phase I trial of the human double minute 2 inhibitor (MK-8242) in patients with refractory/recurrent acute myelogenous leukemia (AML). Leuk. Res. 2016, 48, 92-100. [CrossRef]

121. Wagner, A.J.; Banerji, U.; Mahipal, A.; Somaiah, N.; Hirsch, H.; Fancourt, C.; Johnson-Levonas, A.O.; Lam, R.; Meister, A.K.; Russo, G.; et al. Phase I Trial of the Human Double Minute 2 Inhibitor MK-8242 in Patients With Advanced Solid Tumors. J. Clin. Oncol. 2017, 35, 1304-1311. [CrossRef]

122. Sun, D.; Li, Z.; Rew, Y.; Gribble, M.; Bartberger, M.D.; Beck, H.P.; Canon, J.; Chen, A.; Chen, X.; Chow, D.; et al. Discovery of AMG 232, a Potent, Selective, and Orally Bioavailable MDM2-p53 Inhibitor in Clinical Development. J. Med. Chem. 2014, 57, 1454-1472. [CrossRef] [PubMed]

123. Canon, J.; Osgood, T.; Olson, S.H.; Saiki, A.Y.; Robertson, R.; Yu, D.; Eksterowicz, J.; Ye, Q.; Jin, L.; Chen, A.; et al. The MDM2 Inhibitor AMG 232 Demonstrates Robust Antitumor Efficacy and Potentiates the Activity of p53-Inducing Cytotoxic Agents. Mol. Cancer Ther. 2015, 14, 649-658. [CrossRef]

124. Werner, L.R.; Huang, S.; Francis, D.M.; Armstrong, E.A.; Ma, F.; Li, C.; Iyer, G.; Canon, J.; Harari, P.M. Small Molecule Inhibition of MDM2-p53 Interaction Augments Radiation Response in Human Tumors. Mol. Cancer Ther. 2015, 14, 1994-2003. [CrossRef] [PubMed]

125. Erba, H.P.; Becker, P.S.; Shami, P.J.; Grunwald, M.R.; Flesher, D.L.; Zhu, M.; Rasmussen, E.; Henary, H.A.; Anderson, A.A.; Wang, E.S. Phase $1 \mathrm{~b}$ study of the MDM2 inhibitor AMG 232 with or without trametinib in relapsed/refractory acute myeloid leukemia. Blood Adv. 2019, 3, 1939-1949. [CrossRef]

126. Gluck, W.L.; Gounder, M.M.; Frank, R.; Eskens, F.; Blay, J.Y.; Cassier, P.A.; Soria, J.-C.; Chawla, S.; De Weger, V.; Wagner, A.J.; et al. Phase 1 study of the MDM2 inhibitor AMG 232 in patients with advanced P53 wild-type solid tumors or multiple myeloma. Investig. New Drugs 2019, 38, 831-843. [CrossRef]

127. Arnhold, V.; Schmelz, K.; Proba, J.; Winkler, A.; Wünschel, J.; Toedling, J.; Deubzer, H.E.; Künkele, A.; Eggert, A.; Schulte, J.H.; et al. Reactivating TP53 signaling by the novel MDM2 inhibitor DS-3032b as a therapeutic option for high-risk neuroblastoma. Oncotarget 2017, 9, 2304-2319. [CrossRef] [PubMed] 
128. Bauer, T.M.; Gounder, M.M.; Weise, A.M.; Schwartz, G.K.; Carvajal, R.D.; Kumar, P.; Zernovak, O.; Beck, A.; Doyle, J.; MendellHarary, J.; et al. A phase 1 study of MDM2 inhibitor DS-3032b in patients with well/de-differentiated liposarcoma (WD/DD LPS), solid tumors (ST) and lymphomas (L). J. Clin. Oncol. 2018, 36, 11514. [CrossRef]

129. Dinardo, C.D.; Rosenthal, M.J.; Andreeff, M.; Zernovak, O.; Kumar, P.; Gajee, R.; Chen, S.; Rosen, M.; Song, S.; Kochan, J.; et al. Phase 1 Dose Escalation Study of MDM2 Inhibitor DS-3032b in Patients with Hematological Malignancies-Preliminary Results. Blood 2016, 128, 593. [CrossRef]

130. Jeay, S.; Ferretti, S.; Holzer, P.; Fuchs, J.; Chapeau, E.A.; Wartmann, M.; Sterker, D.; Romanet, V.; Murakami, M.; Kerr, G.; et al. Dose and Schedule Determine Distinct Molecular Mechanisms Underlying the Efficacy of the p53-MDM2 Inhibitor HDM201. Cancer Res. 2018, 78, 6257-6267. [CrossRef]

131. Holzer, P.; Chène, P.; Ferretti, S.; Furet, P.; Gabriel, T.; Gruenenfelder, B.; Guagnano, V.; Hofmann, F.; Kallen, J.; Mah, R.; et al. Abstract 4855: Discovery of NVP-HDM201-First disclosure of a Next-Generation Mdm2 inhibitor with superior characteristics. Cancer Chem. 2016, 76, 4855. [CrossRef]

132. Ferretti, S.; Rebmann, R.; Berger, M.; Santacroce, F.; Albrecht, G.; Pollehn, K.; Sterker, D.; Wartmann, M.; Hueber, A.; Wiesmann, M.; et al. Abstract 1224: Insights into the mechanism of action of NVP-HDM201, a differentiated and versatile Next-Generation small-molecule inhibitor of Mdm2, under evaluation in phase I clinical trials. Exp. Mol. Ther. 2016, 76, 1224. [CrossRef]

133. Aguilar, A.; Lu, J.; Liu, L.; Du, D.; Bernard, D.; McEachern, D.; Przybranowski, S.; Li, X.; Luo, R.; Wen, B.; et al. Discovery

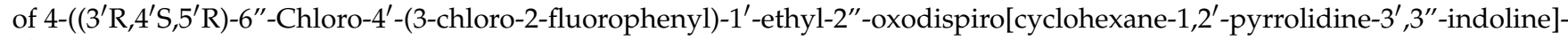
$5^{\prime}$-carboxamido)bicyclo[2.2.2]octane-1-carboxylic Acid (AA-115/APG-115): A Potent and Orally Active Murine Double Minute 2 (MDM2) Inhibitor in Clinical Development. J. Med. Chem. 2017, 60, 2819-2839. [CrossRef] [PubMed]

134. Rasco, D.W.; Lakhani, N.J.; Li, Y.; Men, L.; Wang, H.; Ji, J.; Tang, Y.; Liang, Z.; Amaya, A.; Estkowski, K.; et al. A phase I study of a novel MDM2 antagonist APG-115 in patients with advanced solid tumors. J. Clin. Oncol. 2019, 37, 3126. [CrossRef]

135. Tolcher, A.W.; Karim, R.; Tang, Y.; Wang, H.; Ji, J.; Chen, J.; Kaiser, A.; Sheladia, P.; Ahmad, M.; Liang, Z.; et al. Phase Ib study of a novel, small-molecule MDM2 inhibitor APG-115 combined with pembrolizumab in U.S. patients with metastatic solid tumors. J. Clin. Oncol. 2020, 38, 3512. [CrossRef]

136. Holzer, P.; Masuya, K.; Furet, P.; Kallen, J.; Valat-Stachyra, T.; Ferretti, S.; Berghausen, J.; Bouisset-Leonard, M.; Buschmann, N.; Pissot-Soldermann, C.; et al. Discovery of a Dihydroisoquinolinone Derivative (NVP-CGM097): A Highly Potent and Selective MDM2 Inhibitor Undergoing Phase 1 Clinical Trials in p53wt Tumors. J. Med. Chem. 2015, 58, 6348-6358. [CrossRef]

137. Bykov, V.J.; Issaeva, N.; Shilov, A.; Hultcrantz, M.; Pugacheva, E.; Chumakov, P.; Bergman, J.; Wiman, K.; Selivanova, G. Restoration of the tumor suppressor function to mutant p53 by a low-molecular-weight compound. Nat. Med. 2002, 8, 282-288. [CrossRef] [PubMed]

138. Bykov, V.J.N.; Zache, N.; Stridh, H.; Westman, J.; Bergman, J.; Selivanova, G.; Wiman, K.G. PRIMA-1MET synergizes with cisplatin to induce tumor cell apoptosis. Oncogene 2005, 24, 3484-3491. [CrossRef]

139. Tessoulin, B.; Descamps, G.; Moreau, P.; Maïga, S.; Lodé, L.; Godon, C.; Marionneau-Lambot, S.; Oullier, T.; le Gouill, S.; Amiot, M.; et al. PRIMA-1Met induces myeloma cell death independent of p53 by impairing the GSH/ROS balance. Blood 2014, 124, 1626-1636. [CrossRef] [PubMed]

140. Deneberg, S.; Cherif, H.; Lazarevic, V.; Andersson, P.-O.; Von Euler, M.; Juliusson, G.; Lehmann, S. An open-label phase I dose-finding study of APR-246 in hematological malignancies. Blood Cancer J. 2016, 6, e447. [CrossRef]

141. Ding, K.; Lu, Y.; Nikolovska-Coleska, Z.; Wang, G.; Qiu, S.; Shangary, S.; Gao, W.; Qin, D.; Stuckey, J.; Krajewski, K.; et al. Structure-Based Design of Spiro-oxindoles as Potent, Specific Small-Molecule Inhibitors of the MDM2-p53 Interaction. J. Med. Chem. 2006, 49, 3432-3435. [CrossRef] [PubMed]

142. Shangary, S.; Qin, D.; McEachern, D.; Liu, M.; Miller, R.S.; Qiu, S.; Nikolovska-Coleska, Z.; Ding, K.; Wang, G.; Chen, J.; et al Temporal activation of p53 by a specific MDM2 inhibitor is selectively toxic to tumors and leads to complete tumor growth inhibition. Proc. Natl. Acad. Sci. USA 2008, 105, 3933-3938. [CrossRef]

143. Sasiela, C.A.; Stewart, D.H.; Kitagaki, J.; Safiran, Y.J.; Yang, Y.; Weissman, A.M.; Oberoi, P.; Davydov, I.V.; Goncharova, E.; Beutler, J.A.; et al. Identification of Inhibitors for MDM2 Ubiquitin Ligase Activity from Natural Product Extracts by a Novel High-Throughput Electrochemiluminescent Screen. J. Biomol. Screen. 2008, 13, 229-237. [CrossRef] [PubMed]

144. Issaeva, N.; Bozko, P.; Enge, M.; Protopopova, M.; Verhoef, L.G.G.C.; Masucci, M.; Pramanik, A.; Selivanova, G. Small molecule RITA binds to p53, blocks p53-HDM-2 interaction and activates p53 function in tumors. Nat. Med. 2004, 10, 1321-1328. [CrossRef] [PubMed]

145. Li, W.-D. Cytotoxic effect of a non-peptidic small molecular inhibitor of the p53-HDM2 interaction on tumor cells. World J. Gastroenterol. 2005, 11, 2927-2931. [CrossRef] [PubMed]

146. Kitagaki, J.; Agama, K.K.; Pommier, Y.; Yang, Y.; Weissman, A.M. Targeting tumor cells expressing p53 with a water-soluble inhibitor of Hdm2. Mol. Cancer Ther. 2008, 7, 2445-2454. [CrossRef]

147. Herman, A.G.; Hayano, M.; Poyurovsky, M.V.; Shimada, K.; Skouta, R.; Prives, C.; Stockwell, B.R. Discovery of Mdm2-MdmX E3 Ligase Inhibitors Using a Cell-Based Ubiquitination Assay. Cancer Discov. 2011, 1, 312-325. [CrossRef]

148. Wang, H.; Ma, X.; Ren, S.; Buolamwini, J.K.; Yan, C. A Small-Molecule Inhibitor of MDMX Activates p53 and Induces Apoptosis. Mol. Cancer Ther. 2011, 10, 69-79. [CrossRef] 
149. Huang, H.-L.; Weng, H.-Y.; Wang, L.-Q.; Yu, C.-H.; Huang, Q.-J.; Zhao, P.-P.; Wen, J.-Z.; Zhou, H.; Qu, L.-H. Triggering Fbw7Mediated Proteasomal Degradation of c-Myc by Oridonin Induces Cell Growth Inhibition and Apoptosis. Mol. Cancer Ther. 2012, 11, 1155-1165. [CrossRef]

150. Orlicky, S.; Tang, X.; Neduva, V.; Elowe, N.; Brown, E.D.; Sicheri, F.; Tyers, M. An allosteric inhibitor of substrate recognition by the SCFCdc4 ubiquitin ligase. Nat. Biotechnol. 2010, 28, 733-737. [CrossRef] [PubMed]

151. Chen, Q.; Xie, W.; Kuhn, D.J.; Voorhees, P.M.; Lopez-Girona, A.; Mendy, D.; Corral, L.G.; Krenitsky, V.P.; Xu, W.; Parseval, L.M.-D.; et al. Targeting the p27 E3 ligase SCFSkp2 results in p27- and Skp2-mediated cell-cycle arrest and activation of autophagy. Blood 2008, 111, 4690-4699. [CrossRef] [PubMed]

152. Rico-Bautista, E.; Yang, C.-C.; Lu, L.; Roth, G.P.; A Wolf, D. Chemical genetics approach to restoring p27Kip1 reveals novel compounds with antiproliferative activity in prostate cancer cells. BMC Biol. 2010, 8, 153. [CrossRef]

153. Wu, L.; Grigoryan, A.V.; Li, Y.; Hao, B.; Pagano, M.; Cardozo, T.J. Specific Small Molecule Inhibitors of Skp2-Mediated p27 Degradation. Chem. Biol. 2012, 19, 1515-1524. [CrossRef]

154. Chan, C.-H.; Morrow, J.; Li, C.-F.; Gao, Y.; Jin, G.; Moten, A.; Stagg, L.J.; Ladbury, J.; Cai, Z.; Xu, D.; et al. Pharmacological Inactivation of Skp2 SCF Ubiquitin Ligase Restricts Cancer Stem Cell Traits and Cancer Progression. Cell 2013, 154, 556-568. [CrossRef]

155. Liao, Y.-J.; Bai, H.-Y.; Li, Z.-H.; Zou, J.; Chen, J.-W.; Zheng, F.; Zhang, J.-X.; Mai, S.-J.; Zeng, M.-S.; Sun, H.-D.; et al. Longikaurin A, a natural ent-kaurane, induces G2/M phase arrest via downregulation of Skp2 and apoptosis induction through ROS/JNK/c-Jun pathway in hepatocellular carcinoma cells. Cell Death Dis. 2014, 5, e1137. [CrossRef] [PubMed]

156. Huang, H.-C.; Lin, C.-L.; Lin, J.-K. 1,2,3,4,6-Penta-O-galloyl- $\beta$-d-glucose, Quercetin, Curcumin and Lycopene Induce Cell-Cycle Arrest in MDA-MB-231 and BT474 Cells through Downregulation of Skp2 Protein. J. Agric. Food Chem. 2011, 59, 6765-6775. [CrossRef] [PubMed]

157. Su, J.; Zhou, X.; Wang, L.; Yin, X.; Wang, Z. Curcumin inhibits cell growth and invasion and induces apoptosis through down-regulation of Skp2 in pancreatic cancer cells. Am. J. Cancer Res. 2016, 6, 1949-1962. [PubMed]

158. Wang, L.; Ye, X.; Cai, X.; Su, J.; Ma, R.; Yin, X.; Zhou, X.; Li, H.; Wang, Z. Curcumin suppresses cell growth and invasion and induces apoptosis by down-regulation of Skp2 pathway in glioma cells. Oncotarget 2015, 6, 18027-18037. [CrossRef]

159. James, M.I.; Iwuji, C.; Irving, G.; Karmokar, A.; Higgins, J.A.; Griffin-Teal, N.; Thomas, A.; Greaves, P.; Cai, H.; Patel, S.R.; et al. Curcumin inhibits cancer stem cell phenotypes in ex vivo models of colorectal liver metastases, and is clinically safe and tolerable in combination with FOLFOX chemotherapy. Cancer Lett. 2015, 364, 135-141. [CrossRef] [PubMed]

160. Howells, L.M.; Iwuji, C.O.O.; Irving, G.R.B.; Barber, S.; Walter, H.; Sidat, Z.; Griffin-Teall, N.; Singh, R.; Foreman, N.; Patel, S.R.; et al. Curcumin Combined with FOLFOX Chemotherapy Is Safe and Tolerable in Patients with Metastatic Colorectal Cancer in a Randomized Phase IIa Trial. J. Nutr. 2019, 149, 1133-1139. [CrossRef]

161. Blees, J.S.; Bokesch, H.R.; Rübsamen, D.; Schulz, K.; Milke, L.; Bajer, M.M.; Gustafson, K.R.; Henrich, C.J.; McMahon, J.B.; Colburn, N.H.; et al. Erioflorin Stabilizes the Tumor Suppressor Pdcd4 by Inhibiting Its Interaction with the E3-ligase $\beta$-TrCP1. PLoS ONE 2012, 7, e46567. [CrossRef]

162. Ward, C.C.; Kleinman, J.I.; Brittain, S.M.; Lee, P.S.; Chung, C.Y.-S.; Kim, K.; Petri, Y.; Thomas, J.R.; Tallarico, J.A.; McKenna, J.M.; et al. Covalent Ligand Screening Uncovers a RNF4 E3 Ligase Recruiter for Targeted Protein Degradation Applications. ACS Chem. Biol. 2019, 14, 2430-2440. [CrossRef]

163. Flygare, J.A.; Beresini, M.; Budha, N.; Chan, H.; Chan, I.T.; Cheeti, S.; Cohen, F.; Deshayes, K.; Doerner, K.; Eckhardt, S.G.; et al. Discovery of a Potent Small-Molecule Antagonist of Inhibitor of Apoptosis (IAP) Proteins and Clinical Candidate for the Treatment of Cancer (GDC-0152). J. Med. Chem. 2012, 55, 4101-4113. [CrossRef] [PubMed]

164. Chang, Y.-C.; Kondapuram, S.K.; Yang, T.-H.; Syed, S.B.; Cheng, S.M.; Lin, T.-Y.; Lin, Y.-C.; Coumar, M.S.; Chang, J.-Y.; Leung, E.; et al. The SMAC mimetic LCL161 is a direct ABCB1/MDR1-ATPase activity modulator and BIRC5/Survivin expression down-regulator in cancer cells. Toxicol. Appl. Pharmacol. 2020, 401, 115080. [CrossRef] [PubMed]

165. Tian, A.; Wilson, G.S.; Lie, S.; Wu, G.; Hu, Z.; Hebbard, L.; Duan, W.; George, J.; Qiao, L. Synergistic effects of IAP inhibitor LCL161 and paclitaxel on hepatocellular carcinoma cells. Cancer Lett. 2014, 351, 232-241. [CrossRef]

166. Shekhar, T.M.; Burvenich, I.J.G.; Harris, M.A.; Rigopoulos, A.; Zanker, D.; Spurling, A.; Parker, B.S.; Walkley, C.R.; Scott, A.M.; Hawkins, C.J. Smac mimetics LCL161 and GDC-0152 inhibit osteosarcoma growth and metastasis in mice. BMC Cancer 2019, 19, 1-18. [CrossRef] [PubMed]

167. Infante, J.R.; Dees, E.C.; Olszanski, A.J.; Dhuria, S.V.; Sen, S.; Cameron, S.; Cohen, R.B. Phase I Dose-Escalation Study of LCL161, an Oral Inhibitor of Apoptosis Proteins Inhibitor, in Patients with Advanced Solid Tumors. J. Clin. Oncol. 2014, 32, 3103-3110. [CrossRef]

168. Cai, Q.; Sun, H.; Peng, Y.; Lu, J.; Nikolovska-Coleska, Z.; McEachern, D.; Liu, L.; Qiu, S.; Yang, C.-Y.; Miller, R.; et al. A Potent and Orally Active Antagonist (SM-406/AT-406) of Multiple Inhibitor of Apoptosis Proteins (IAPs) in Clinical Development for Cancer Treatment. J. Med. Chem. 2011, 54, 2714-2726. [CrossRef] [PubMed]

169. Miura, K.; Fujibuchi, W.; Ishida, K.; Naitoh, T.; Ogawa, H.; Ando, T.; Yazaki, N.; Watanabe, K.; Haneda, S.; Shibata, C.; et al. Inhibitor of apoptosis protein family as diagnostic markers and therapeutic targets of colorectal cancer. Surg. Today 2011, 41, 175-182. [CrossRef] [PubMed]

170. Brunckhorst, M.K.; Lerner, D.; Wang, S.; Yu, Q. AT-406, an orally active antagonist of multiple inhibitor of apoptosis proteins, inhibits progression of human ovarian cancer. Cancer Biol. Ther. 2012, 13, 804-811. [CrossRef] 
171. Hurwitz, H.I.; Smith, D.C.; Pitot, H.C.; Brill, J.M.; Chugh, R.; Rouits, E.; Rubin, J.; Strickler, J.; Vuagniaux, G.; Sorensen, J.M.; et al. Safety, pharmacokinetics, and pharmacodynamic properties of oral DEBIO1143 (AT-406) in patients with advanced cancer: Results of a first-in-man study. Cancer Chemother. Pharmacol. 2015, 75, 851-859. [CrossRef]

172. Sun, X.-S.; Tao, Y.; Le Tourneau, C.; Pointreau, Y.; Sire, C.; Kaminsky, M.-C.; Coutte, A.; Alfonsi, M.; Boisselier, P.; Martin, L.; et al. Debio 1143 and high-dose cisplatin chemoradiotherapy in high-risk locoregionally advanced squamous cell carcinoma of the head and neck: A double-blind, multicentre, randomised, phase 2 study. Lancet Oncol. 2020, 21, 1173-1187. [CrossRef]

173. Katragadda, L.; Carter, B.Z.; Borthakur, G. XIAP antisense therapy with AEG 35156 in acute myeloid leukemia. Expert Opin. Investig. Drugs 2013, 22, 663-670. [CrossRef]

174. Lee, A.S.; Zee, B.C.; Cheung, F.Y.; Kwong, P.; Cheng, A.C.K.; Lai, M.; Kwok, C.; Chong, M.; Jolivet, J.; Chiang, C.L.; et al. Randomized phase II study of the x-linked inhibitor of apoptosis (XIAP) antisense AEG35156 in combination with sorafenib in patients with advanced hepatocellular carcinoma (HCC). J. Clin. Oncol. 2012, 30, 4105. [CrossRef]

175. Zhou, L.; Chen, S.; Zhang, Y.; Kmieciak, M.; Leng, Y.; Li, L.; Lin, H.; Turner, J.; Sullivan, D.; Dai, Y.; et al. Abstract 3020 : Targeting both canonical and non-canonical NF-kB pathways by the IAP antagonist birinapant potentiates bortezomib anti-myeloma activity. Cancer Res. 2016, 76, 3020. [CrossRef]

176. Graham, M.A.; Mitsuuchi, Y.; Burns, J.; Chunduru, S.; Benetatos, C.; McKinlay, M.; Weng, D.; Wick, M.J.; Tolcher, A.W.; Papadopoulos, K.; et al. Abstract A25: Phase 1 PK/PD analysis of the Smac-mimetic TL32711 demonstrates potent and sustained cIAP1 suppression in patient PBMCs and tumor biopsies. Apoptosis Necrosis Autophagy 2011, 10, A25. [CrossRef]

177. Nakahara, T.; Takeuchi, M.; Kinoyama, I.; Minematsu, T.; Shirasuna, K.; Matsuhisa, A.; Kita, A.; Tominaga, F.; Yamanaka, K.; Kudoh, M.; et al. YM155, a Novel Small-Molecule Survivin Suppressant, Induces Regression of Established Human HormoneRefractory Prostate Tumor Xenografts. Cancer Res. 2007, 67, 8014-8021. [CrossRef] [PubMed]

178. Kelly, R.J.; Thomas, A.; Rajan, A.; Chun, G.; Lopez-Chavez, A.; Szabo, E.; Spencer, S.; Carter, C.A.; Guha, U.; Khozin, S.; et al. A phase I/II study of sepantronium bromide (YM155, survivin suppressor) with paclitaxel and carboplatin in patients with advanced non-small-cell lung cancer. Ann. Oncol. 2013, 24, 2601-2606. [CrossRef]

179. Brenke, J.K.; Popowicz, G.M.; Schorpp, K.; Rothenaigner, I.; Roesner, M.; Meininger, I.; Kalinski, C.; Ringelstetter, L.; R'Kyek, O.; Jürjens, G.; et al. Targeting TRAF6 E3 ligase activity with a small-molecule inhibitor combats autoimmunity. J. Biol. Chem. 2018, 293, 13191-13203. [CrossRef]

180. Chen, B.; Coon, T.; Glasser, J.; McVerry, B.; Zhao, J.; Zhao, Y.; Zou, C.; Ellis, B.; Sciurba, H.; Zhang, Y.; et al. A combinatorial F box protein directed pathway controls TRAF adaptor stability to regulate inflammation. Nat. Immunol. 2013, 14, 470-479. [CrossRef]

181. Mallampalli, R.K.; Coon, T.A.; Glasser, J.R.; Wang, C.; Dunn, S.R.; Weathington, N.M.; Zhao, J.; Zou, C.; Zhao, Y.; Chen, B.B. Targeting F Box Protein Fbxo3 to Control Cytokine-Driven Inflammation. J. Immunol. 2013, 191, 5247-5255. [CrossRef]

182. Tian, M.; Zeng, T.; Liu, M.; Han, S.; Lin, H.; Lin, Q.; Li, L.; Jiang, T.; Li, G.; Lin, H.; et al. A cell-based high-throughput screening method based on a ubiquitin-reference technique for identifying modulators of E3 ligases. J. Biol. Chem. 2019, 294, 2880-5770. [CrossRef]

183. Peter, S.; Bultinck, J.; Myant, K.; A Jaenicke, L.; Walz, S.; Müller, J.; Gmachl, M.; Treu, M.; Boehmelt, G.; Ade, C.P.; et al. Tumor cell-specific inhibition of MYC function using small molecule inhibitors of the HUWE 1 ubiquitin ligase. EMBO Mol. Med. 2014,6, 1525-1541. [CrossRef] [PubMed]

184. Crawford, L.J.; Campbell, D.C.; Morgan, J.J.; Lawson, M.A.; Down, J.M.; Chauhan, D.; McAvera, R.M.; Morris, T.C.; Hamilton, C.; Krishnan, A.; et al. The E3 ligase HUWE1 inhibition as a therapeutic strategy to target MYC in multiple myeloma. Oncogene 2020, 39, 5001-5014. [CrossRef] [PubMed]

185. Celegato, M.; Messa, L.; Goracci, L.; Mercorelli, B.; Bertagnin, C.; Spyrakis, F.; Suarez, I.; Cousido-Siah, A.; Travé, G.; Banks, L.; et al. A novel small-molecule inhibitor of the human papillomavirus E6-p53 interaction that reactivates p53 function and blocks cancer cells growth. Cancer Lett. 2020, 470, 115-125. [CrossRef] [PubMed]

186. Cherry, J.J.; Rietz, A.; Malinkevich, A.; Liu, Y.; Xie, M.; Bartolowits, M.; Davisson, V.J.; Baleja, J.D.; Androphy, E.J. Structure Based Identification and Characterization of Flavonoids That Disrupt Human Papillomavirus-16 E6 Function. PLoS ONE 2013, 8, e84506. [CrossRef]

187. Strickson, S.; Campbell, D.G.; Emmerich, C.H.; Knebel, A.; Plater, L.; Ritorto, M.S.; Shpiro, N.; Cohen, P. The anti-inflammatory drug BAY 11-7082 suppresses the MyD88-dependent signalling network by targeting the ubiquitin system. Biochem. J. 2013, 451, 427-437. [CrossRef]

188. Chen, L.; Ruan, Y.; Wang, X.; Min, L.; Shen, Z.; Sun, Y.; Qin, X. BAY 11-7082, a nuclear factor-kB inhibitor, induces apoptosis and S phase arrest in gastric cancer cells. J. Gastroenterol. 2013, 49, 864-874. [CrossRef]

189. Katsuya, K.; Oikawa, D.; Iio, K.; Obika, S.; Hori, Y.; Urashima, T.; Ayukawa, K.; Tokunaga, F. Small-molecule inhibitors of linear ubiquitin chain assembly complex (LUBAC), HOIPINs, suppress NF-kB signaling. Biochem. Biophys. Res. Commun. 2019, 509, 700-706. [CrossRef] [PubMed]

190. Oikawa, D.; Sato, Y.; Ohtake, F.; Komakura, K.; Hanada, K.; Sugawara, K.; Terawaki, S.; Mizukami, Y.; Phuong, H.T.; Iio, K.; et al. Molecular bases for HOIPINs-mediated inhibition of LUBAC and innate immune responses. Commun. Biol. $2020,3,163$. [CrossRef]

191. Keating, M.J.; Bach, C.; Yasothan, U.; Kirkpatrick, P. Bendamustine. Nat. Rev. Drug Discov. 2008, 7, 473-474. [CrossRef] 
192. Damaj, G.; Gressin, R.; Bouabdallah, K.; Cartron, G.; Choufi, B.; Gyan, E.; Banos, A.; Jaccard, A.; Park, S.; Tournilhac, O.; et al. Results from a Prospective, Open-Label, Phase II Trial of Bendamustine in Refractory or Relapsed T-Cell Lymphomas: The BENTLY Trial. J. Clin. Oncol. 2013, 31, 104-110. [CrossRef] [PubMed]

193. Weidmann, E.; Kim, S.-Z.; Rost, A.; Schuppert, H.; Seipelt, G.; Hoelzer, D.; Mitrou, P.S. Bendamustine is effective in relapsed or refractory aggressive non-Hodgkin's lymphoma. Ann. Oncol. 2002, 13, 1285-1289. [CrossRef] [PubMed]

194. Weidmann, E.; Neumann, A.; Fauth, F.; Atmaca, A.; Al-Batran, S.E.; Pauligk, C.; Jäger, E. Phase II study of bendamustine in combination with rituximab as first-line treatment in patients 80 years or older with aggressive B-cell lymphomas. Ann. Oncol. 2011, 22, 1839-1844. [CrossRef] [PubMed]

195. Flinn, I.W.; Panayiotidis, P.; Afanasyev, B.; Janssens, A.; Grosicki, S.; Homenda, W.; Smolej, L.; Kuliczkowski, K.; Doubek, M.; Domnikova, N.; et al. A phase 2, multicenter study investigating ofatumumab and bendamustine combination in patients with untreated or relapsed CLL. Am. J. Hematol. 2016, 91, 900-906. [CrossRef]

196. Midgley, C.A.; Lane, D.P. p53 protein stability in tumour cells is not determined by mutation but is dependent on Mdm2 binding. Oncogene 1997, 15, 1179-1189. [CrossRef] [PubMed]

197. Haupt, Y.; Mayat, R.; Kazazt, A.; Orent, M. Mdm2 promotes the rapid degradation of p53. Nature 1997, 387, 296-299. [CrossRef] [PubMed]

198. Tisato, V.; Voltan, R.; Gonelli, A.; Secchiero, P.; Zauli, G. MDM2/X inhibitors under clinical evaluation: Perspectives for the management of hematological malignancies and pediatric cancer. J. Hematol. Oncol. 2017, 10, 1-17. [CrossRef] [PubMed]

199. Vassilev, L.T.; Vu, B.T.; Graves, B.; Carvajal, D.; Podlaski, F.; Filipovic, Z.; Kong, N.; Kammlott, U.; Lukacs, C.; Klein, C.; et al. In Vivo Activation of the p53 Pathway by Small-Molecule Antagonists of MDM2. Science 2004, 303, 844-848. [CrossRef] [PubMed]

200. Lau, L.M.S.; Nugent, J.K.; Zhao, X.; Irwin, M.S. HDM2 antagonist Nutlin-3 disrupts p73-HDM2 binding and enhances p73 function. Oncogene 2007, 27, 997-1003. [CrossRef]

201. Zhang, Z.; Wang, H.; Li, M.; Rayburn, E.R.; Agrawal, S.; Zhang, R. Stabilization of E2F1 protein by MDM2 through the E2F1 ubiquitination pathway. Oncogene 2005, 24, 7238-7247. [CrossRef]

202. Furet, P.; Masuya, K.; Kallen, J.; Stachyra-Valat, T.; Ruetz, S.; Guagnano, V.; Holzer, P.; Mah, R.; Stutz, S.; Vaupel, A.; et al. Discovery of a novel class of highly potent inhibitors of the p53-MDM2 interaction by structure-based design starting from a conformational argument. Bioorg. Med. Chem. Lett. 2016, 26, 4837-4841. [CrossRef] [PubMed]

203. Skaar, J.R.; Pagan, J.; Pagano, M. SCF ubiquitin ligase-targeted therapies. Nat. Rev. Drug Discov. 2014, 13, 889-903. [CrossRef] [PubMed]

204. Wang, Z.; Liu, P.; Inuzuka, H.; Wei, W. Roles of F-box proteins in cancer. Nat. Rev. Cancer 2014, 14, 233-247. [CrossRef] [PubMed]

205. Yumimoto, K.; Yamauchi, Y.; Nakayama, K.I. F-Box Proteins and Cancer. Cancers 2020, 12, 1249. [CrossRef] [PubMed]

206. Aghajan, M.; Jonai, N.; Flick, K.; Fu, F.; Luo, M.; Cai, X.; Ouni, I.; Pierce, N.; Tang, X.; Lomenick, B.; et al. Chemical genetics screen for enhancers of rapamycin identifies a specific inhibitor of an SCF family E3 ubiquitin ligase. Nat. Biotechnol. 2010, $28,738-742$. [CrossRef] [PubMed]

207. Bjornsti, M.-A.; Houghton, P.J. The tor pathway: A target for cancer therapy. Nat. Rev. Cancer 2004, 4, 335-348. [CrossRef] [PubMed]

208. Easton, J.B.; Houghton, P.J. mTOR and cancer therapy. Oncogene 2006, 25, 6436-6446. [CrossRef]

209. Cloughesy, T.F.; Yoshimoto, K.; Nghiemphu, P.; Brown, K.; Dang, J.; Zhu, S.; Hsueh, T.; Chen, Y.; Wang, W.; Youngkin, D.; et al. Antitumor Activity of Rapamycin in a Phase I Trial for Patients with Recurrent PTEN-Deficient Glioblastoma. PLoS Med. 2008, 5, e8. [CrossRef]

210. Su, J.; Wang, L.; Yin, X.; Zhao, Z.; Hou, Y.; Ye, X.; Zhou, X.; Wang, Z. Rottlerin exhibits anti-cancer effect through inactivation of S phase kinase-associated protein 2 in pancreatic cancer cells. Am. J. Cancer Res. 2016, 6, 2178-2191. [PubMed]

211. Yin, X.; Zhang, Y.; Su, J.; Hou, Y.; Wang, L.; Ye, X.; Zhao, Z.; Zhou, X.; Li, Y.; Wang, Z. Rottlerin exerts its anti-tumor activity through inhibition of Skp2 in breast cancer cells. Oncotarget 2016, 7, 66512-66524. [CrossRef]

212. Li, X.; Yokoyama, N.N.; Zhang, S.; Ding, L.; Liu, H.-M.; Lilly, M.B.; Mercola, D.; Zi, X. Flavokawain A induces deNEDDylation and Skp2 degradation leading to inhibition of tumorigenesis and cancer progression in the TRAMP transgenic mouse model. Oncotarget 2015, 6, 41809-41824. [CrossRef]

213. Zhou, L.; Yu, X.; Li, M.; Gong, G.; Liu, W.; Li, T.; Zuo, H.; Li, W.; Gao, F.; Liu, H. Cdh1-mediated Skp2 degradation by dioscin reprogrammes aerobic glycolysis and inhibits colorectal cancer cells growth. EBioMedicine 2020, 51, 102570. [CrossRef] [PubMed]

214. Benary, U.; Wolf, J. Wolf Controlling Nuclear NF-кB Dynamics by $\beta$-TrCP-Insights from a Computational Model. Biomedicine 2019, 7, 40. [CrossRef]

215. Nalepa, G.; Rolfe, M.; Harper, J. Drug discovery in the ubiquitin-proteasome system. Nat. Rev. Drug Discov. 2006, 5, 596-613. [CrossRef]

216. Müerköster, S.; Arlt, A.; Sipos, B.; Witt, M.; Großmann, M.; Klöppel, G.; Kalthoff, H.; Fölsch, U.R.; Schäfer, H. Increased Expression of the E3-Ubiquitin Ligase Receptor Subunit $\beta$ TRCP1 Relates to Constitutive Nuclear Factor- $\mathrm{kB}$ Activation and Chemoresistance in Pancreatic Carcinoma Cells. Cancer Res. 2005, 65, 1316-1324. [CrossRef]

217. Nakajima, H.; Fujiwara, H.; Furuichi, Y.; Tanaka, K.; Shimbara, N. A novel small-molecule inhibitor of NF- $\mathrm{kB}$ signaling. Biochem. Biophys. Res. Commun. 2008, 368, 1007-1013. [CrossRef] [PubMed]

218. Plechanovová, A.; Jaffray, E.G.; McMahon, S.A.; Johnson, K.A.; Navrátilová, I.; Naismith, J.; Hay, R.T. Mechanism of ubiquitylation by dimeric RING ligase RNF4. Nat. Struct. Mol. Biol. 2011, 18, 1052-1059. [CrossRef] [PubMed] 
219. Hunter, A.M.; Lacasse, E.C.; Korneluk, R.G. The inhibitors of apoptosis (IAPs) as cancer targets. Apoptosis 2007, 12, 1543-1568. [CrossRef]

220. Wu, H.; Tschopp, J.; Lin, S.-C. Smac Mimetics and TNF $\alpha$ : A Dangerous Liaison? Cell 2007, 131, 655-658. [CrossRef]

221. Cohen, P.; Tcherpakov, M. Will the Ubiquitin System Furnish as Many Drug Targets as Protein Kinases? Cell 2010, 143, 686-693. [CrossRef] [PubMed]

222. Inoue, J.-I.; Ishidab, T.; Tsukamotoa, N.; Kobayashia, N.; Naitoa, A.; Azumaa, S.; Yamamotoa, T. Tumor Necrosis Factor ReceptorAssociated Factor (TRAF) Family: Adapter Proteins That Mediate Cytokine Signaling. Exp. Cell Res. 2000, 254, 14-24. [CrossRef] [PubMed]

223. Wajant, H.; Henkler, F.; Scheurich, P. The TNF-receptor-associated factor family: Scaffold molecules for cytokine receptors, kinases and their regulators. Cell. Signal. 2001, 13, 389-400. [CrossRef]

224. Xie, P. TRAF molecules in cell signaling and in human diseases. J. Mol. Signal. 2013, 8, 7. [CrossRef] [PubMed]

225. Ostuni, R.; Zanoni, I.; Granucci, F. Deciphering the complexity of Toll-like receptor signaling. Cell. Mol. Life Sci. 2010, 67, 4109-4134. [CrossRef] [PubMed]

226. Starczynowski, D.T.; Lockwood, W.W.; Deléhouzée, S.; Chari, R.; Wegrzyn, J.; Fuller, M.; Tsao, M.-S.; Lam, S.; Gazdar, A.F.; Lam, W.L.; et al. TRAF6 is an amplified oncogene bridging the RAS and NF-kB pathways in human lung cancer. J. Clin. Investig. 2011, 121, 4095-4105. [CrossRef]

227. Meng, Q.; Zheng, M.; Liu, H.; Song, C.; Zhang, W.; Yan, J.; Qin, L.; Liu, X. TRAF6 regulates proliferation, apoptosis, and invasion of osteosarcoma cell. Mol. Cell. Biochem. 2012, 371, 177-186. [CrossRef] [PubMed]

228. Zhong, L.; Cao, F.; You, Q. Effect of TRAF6 on the biological behavior of human lung adenocarcinoma cell. Tumor Biol. 2012, 34, 231-239. [CrossRef]

229. Owais, A.; Mishra, R.K.; Kiyokawa, H. The HECT E3 ligase E6AP/UBE3A as a Therapeutic Target in Cancer and Neurological Disorders. Cancers 2020, 12, 2108. [CrossRef]

230. Watt, J.E.; Hughes, G.R.; Walpole, S.; Monaco, S.; Stephenson, G.R.; Page, P.C.B.; Hemmings, A.M.; Angulo, J.; Chantry, A. Discovery of Small Molecule WWP2 Ubiquitin Ligase Inhibitors. Chem. A Eur. J. 2018, 24, 17677-17680. [CrossRef]

231. Wang, M.; Guo, L.; Wu, Q.; Zeng, T.; Lin, Q.; Qiao, Y.; Wang, Q.; Liu, M.; Zhang, X.; Ren, L.; et al. ATR/Chk1/Smurf1 pathway determines cell fate after DNA damage by controlling RhoB abundance. Nat. Commun. 2014, 5, 4901. [CrossRef]

232. Kao, S.-H.; Wu, H.-T.; Wu, K.-J. Ubiquitination by HUWE1 in tumorigenesis and beyond. J. Biomed. Sci. 2018, 25, 1-15. [CrossRef]

233. Ricci-López, J.; Vidal-Limon, A.; Zunñiga, M.; Jimènez, V.A.; Alderete, J.B.; Brizuela, C.A.; Aguila, S. Molecular modeling simulation studies reveal new potential inhibitors against HPV E6 protein. PLoS ONE 2019, 14, e0213028. [CrossRef]

234. Li, X.; Elmira, E.; Rohondia, S.; Wang, J.; Liu, J.; Dou, Q.P. A patent review of the ubiquitin ligase system: 2015-2018. Expert Opin. Ther. Patents 2018, 28, 919-937. [CrossRef] [PubMed]

235. Yamagishi, Y.; Shoji, I.; Miyagawa, S.; Kawakami, T.; Katoh, T.; Goto, Y.; Suga, H. Natural Product-Like Macrocyclic N-MethylPeptide Inhibitors against a Ubiquitin Ligase Uncovered from a Ribosome-Expressed De Novo Library. Chem. Biol. 2011, 18, 1562-1570. [CrossRef]

236. Mund, T.; Lewis, M.J.; Maslen, S.; Pelham, H.R. Peptide and small molecule inhibitors of HECT-type ubiquitin ligases. Proc. Natl. Acad. Sci. USA 2014, 111, 16736-16741. [CrossRef]

237. Wang, P.; Dai, X.; Jiang, W.; Li, Y.; Wei, W. RBR E3 ubiquitin ligases in tumorigenesis. Semin. Cancer Biol. 2020, 67, 131-144. [CrossRef] [PubMed]

238. Kirisako, T.; Kamei, K.; Murata, S.; Kato, M.; Fukumoto, H.; Kanie, M.; Sano, S.; Tokunaga, F.; Tanaka, K.; Iwai, K. A ubiquitin ligase complex assembles linear polyubiquitin chains. EMBO J. 2006, 25, 4877-4887. [CrossRef] [PubMed]

239. Gerlach, B.; Cordier, S.M.; Schmukle, A.C.; Emmerich, C.H.; Rieser, E.; Haas, T.; Webb, A.I.; Rickard, J.A.; Anderton, H.; Wong, W.W.-L.; et al. Linear ubiquitination prevents inflammation and regulates immune signalling. Nat. Cell Biol. 2011, 471, 591-596. [CrossRef] [PubMed]

240. Ikeda, F.; Deribe, Y.L.; Skånland, S.S.; Stieglitz, B.; Grabbe, C.; Franz-Wachtel, M.; Van Wijk, S.J.L.; Goswami, P.; Nagy, V.; Terzic, J.; et al. SHARPIN forms a linear ubiquitin ligase complex regulating NF-kB activity and apoptosis. Nat. Cell Biol. 2011, 471, 637-641. [CrossRef] [PubMed]

241. Tokunaga, F.; Nakagawa, T.; Nakahara, M.; Saeki, Y.; Taniguchi, M.; Sakata, S.-I.; Tanaka, K.; Nakano, H.; Iwai, K. SHARPIN is a component of the NF-кB-activating linear ubiquitin chain assembly complex. Nat. Cell Biol. 2011, 471, 633-636. [CrossRef] [PubMed]

242. Yang, Y.; Schmitz, R.; Mitala, J.; Whiting, A.L.; Xiao, W.; Ceribelli, M.; Wright, G.W.; Zhao, H.; Yang, Y.; Xu, W.; et al. Essential Role of the Linear Ubiquitin Chain Assembly Complex in Lymphoma Revealed by Rare Germline Polymorphisms. Cancer Discov. 2014, 4, 480-493. [CrossRef]

243. Sakamoto, H.; Egashira, S.; Saito, N.; Kirisako, T.; Miller, S.; Sasaki, Y.; Matsumoto, T.; Shimonishi, M.; Komatsu, T.; Terai, T.; et al. Gliotoxin Suppresses NF-кB Activation by Selectively Inhibiting Linear Ubiquitin Chain Assembly Complex (LUBAC). ACS Chem. Biol. 2015, 10, 675-681. [CrossRef] [PubMed]

244. De Cesare, V.; Johnson, C.; Barlow, V.; Hastie, J.; Knebel, A.; Trost, M. The MALDI-TOF E2/E3 Ligase Assay as Universal Tool for Drug Discovery in the Ubiquitin Pathway. Cell Chem. Biol. 2018, 25, 1117-1127.e4. [CrossRef] 
245. Johansson, H.; Tsai, Y.-C.I.; Fantom, K.; Chung, C.-W.; Kümper, S.; Martino, L.; Thomas, D.A.; Eberl, H.C.; Muelbaier, M.; House, D.; et al. Fragment-Based Covalent Ligand Screening Enables Rapid Discovery of Inhibitors for the RBR E3 Ubiquitin Ligase HOIP. J. Am. Chem. Soc. 2019, 141, 2703-2712. [CrossRef] [PubMed]

246. Tsai, Y.-C.I.; Johansson, H.; Dixon, D.; Martin, S.; Chung, C.-W.; Clarkson, J.; House, D.; Rittinger, K. Single-Domain Antibodies as Crystallization Chaperones to Enable Structure-Based Inhibitor Development for RBR E3 Ubiquitin Ligases. Cell Chem. Biol. 2020, 27, 83-93.e9. [CrossRef] [PubMed]

247. Eletr, Z.M.; Wilkinson, K.D. Regulation of proteolysis by human deubiquitinating enzymes. Biochim. Biophys. Acta Bioenerg. 2014, 1843, 114-128. [CrossRef]

248. Zhang, W.; Sidhu, S.S. Development of inhibitors in the ubiquitination cascade. FEBS Lett. 2014, 588, 356-367. [CrossRef]

249. Colland, F.; Formstecher, E.; Jacq, X.; Reverdy, C.; Planquette, C.; Conrath, S.; Trouplin, V.; Bianchi, J.; Aushev, V.N.; Camonis, J.; et al. Small-molecule inhibitor of USP7/HAUSP ubiquitin protease stabilizes and activates p53 in cells. Mol. Cancer Ther. 2009, 8, 2286-2295. [CrossRef]

250. Li, M.; Chen, D.; Shiloh, A.; Luo, J.; Nikolaev, A.Y.; Qin, J.; Gu, W. Deubiquitination of p53 by HAUSP is an important pathway for p53 stabilization. Nat. Cell Biol. 2002, 416, 648-653. [CrossRef]

251. Li, M.; Brooks, C.L.; Kon, N.; Gu, W. A Dynamic Role of HAUSP in the p53-Mdm2 Pathway. Mol. Cell 2004, 13, 879-886. [CrossRef]

252. Reverdy, C.; Conrath, S.; Lopez, R.; Planquette, C.; Atmanene, C.; Collura, V.; Harpon, J.; Battaglia, V.; Vivat, V.; Sippl, W.; et al. Discovery of Specific Inhibitors of Human USP7/HAUSP Deubiquitinating Enzyme. Chem. Biol. 2012, 19, 467-477. [CrossRef]

253. Chauhan, D.; Tian, Z.; Nicholson, B.; Kumar, G.S.; Zhou, B.; Carrasco, R.; McDermott, J.L.; Leach, C.A.; Fulcinniti, M.; Kodrasov, M.P.; et al. A small molecule inhibitor of ubiquitin-specific protease-7 induces apoptosis in multiple myeloma cells and overcomes bortezomib resistance. Cancer Cell 2012, 22, 345-358. [CrossRef] [PubMed]

254. Weinstock, J.; Wu, J.; Cao, P.; Kingsbury, W.D.; McDermott, J.L.; Kodrasov, M.P.; McKelvey, D.M.; Kumar, K.G.S.; Goldenberg, S.J.; Mattern, M.R.; et al. Selective Dual Inhibitors of the Cancer-Related Deubiquitylating Proteases USP7 and USP47. ACS Med. Chem. Lett. 2012, 3, 789-792. [CrossRef]

255. Fan, Y.-H.; Cheng, J.; A Vasudevan, S.; Dou, J.; Zhang, H.; Patel, R.H.; Ma, I.T.; Rojas, Y.; Zhao, Y.; Yu, Y.; et al. USP7 inhibitor P22077 inhibits neuroblastoma growth via inducing p53-mediated apoptosis. Cell Death Dis. 2013, 4, e867. [CrossRef] [PubMed]

256. Altun, M.; Kramer, H.B.; Willems, L.I.; McDermott, J.L.; Leach, C.A.; Goldenberg, S.J.; Kumar, K.S.; Konietzny, R.; Fischer, R.; Kogan, E.; et al. Activity-Based Chemical Proteomics Accelerates Inhibitor Development for Deubiquitylating Enzymes. Chem. Biol. 2011, 18, 1401-1412. [CrossRef]

257. Pozhidaeva, A.; Valles, G.; Wang, F.; Wu, J.; Sterner, D.E.; Nguyen, P.; Weinstock, J.; Kumar, K.S.; Kanyo, J.; Wright, D.; et al. USP7-Specific Inhibitors Target and Modify the Enzyme's Active Site via Distinct Chemical Mechanisms. Cell Chem. Biol. 2017, 24, 1501-1512.e5. [CrossRef] [PubMed]

258. Tavana, O.; Gu, W. Modulation of the p53/MDM2 interplay by HAUSP inhibitors. J. Mol. Cell Biol. 2017, 9, 45-52. [CrossRef] [PubMed]

259. Gavory, G.; O’Dowd, C.R.; Helm, M.D.; Flasz, J.; Arkoudis, E.; Dossang, A.; Hughes, C.; Cassidy, E.; McClelland, K.; Odrzywol, E.; et al. Discovery and characterization of highly potent and selective allosteric USP7 inhibitors. Nat. Chem. Biol. 2018, 14, 118-125. [CrossRef] [PubMed]

260. Di Lello, P.; Pastor, R.; Murray, J.M.; Blake, R.A.; Cohen, F.; Crawford, T.D.; Drobnick, J.; Drummond, J.; Kategaya, L.; Kleinheinz, T.; et al. Discovery of Small-Molecule Inhibitors of Ubiquitin Specific Protease 7 (USP7) Using Integrated NMR and in Silico Techniques. J. Med. Chem. 2017, 60, 10056-10070. [CrossRef] [PubMed]

261. Lamberto, I.; Liu, X.; Seo, H.-S.; Schauer, N.J.; Iacob, R.E.; Hu, W.; Das, D.; Mikhailova, T.; Weisberg, E.L.; Engen, J.R.; et al. Structure-Guided Development of a Potent and Selective Non-covalent Active-Site Inhibitor of USP7. Cell Chem. Biol. 2017, 24, 1490-1500.e11. [CrossRef] [PubMed]

262. Turnbull, A.P.; Ioannidis, S.; Krajewski, W.W.; Pinto-Fernandez, A.; Heride, C.; Martin, A.C.L.; Tonkin, L.M.; Townsend, E.C.; Buker, S.M.; Lancia, D.R.; et al. Molecular basis of USP7 inhibition by selective small-molecule inhibitors. Nature 2017, 550, 481-486. [CrossRef] [PubMed]

263. Chen, J.; Dexheimer, T.S.; Ai, Y.; Liang, Q.; Villamil, M.A.; Inglese, J.; Maloney, D.J.; Jadhav, A.; Simeonov, A.; Zhuang, Z. Selective and Cell-Active Inhibitors of the USP1/ UAF1 Deubiquitinase Complex Reverse Cisplatin Resistance in Non-small Cell Lung Cancer Cells. Chem. Biol. 2011, 18, 1390-1400. [CrossRef] [PubMed]

264. Kobayashi, E.; Hwang, D.; Bheda-Malge, A.; Whitehurst, C.B.; Kabanov, A.V.; Kondo, S.; Aga, M.; Yoshizaki, T.; Pagano, J.S.; Sokolsky, M.; et al. Inhibition of UCH-L1 Deubiquitinating Activity with Two Forms of LDN-57444 Has Anti-Invasive Effects in Metastatic Carcinoma Cells. Int. J. Mol. Sci. 2019, 20, 3733. [CrossRef]

265. Peterson, L.F.; Sun, H.; Liu, Y.; Potu, H.; Kandarpa, M.; Ermann, M.; Courtney, S.M.; Young, M.; Showalter, H.D.; Sun, D.; et al. Targeting deubiquitinase activity with a novel small-molecule inhibitor as therapy for B-cell malignancies. Blood 2015, 125, 3588-3597. [CrossRef]

266. Clancy, A.; Heride, C.; Pinto-Fernández, A.; Elcocks, H.; Kallinos, A.; Kayser-Bricker, K.J.; Wang, W.; Smith, V.; Davis, S.; Fessler, S.; et al. The deubiquitylase USP9X controls ribosomal stalling. J. Cell Biol. 2021, 220. [CrossRef]

267. Zhang, W.; Sidhu, S.S. Allosteric inhibitors hit USP7 hard. Nat. Chem. Biol. 2018, 14, 110-111. [CrossRef] 
268. Kategaya, L.; Di Lello, P.; Rougé, L.; Pastor, R.; Clark, K.R.; Drummond, J.; Kleinheinz, T.; Lin, E.; Upton, J.-P.; Prakash, S.; et al. USP7 small-molecule inhibitors interfere with ubiquitin binding. Nat. Cell Biol. 2017, 550, 534-538. [CrossRef]

269. Cohn, M.A.; Kowal, P.; Yang, K.; Haas, W.; Huang, T.T.; Gygi, S.P.; D'Andrea, A.D. A UAF1-Containing Multisubunit Protein Complex Regulates the Fanconi Anemia Pathway. Mol. Cell 2007, 28, 786-797. [CrossRef]

270. Kee, Y.; D'Andrea, A.D. Expanded roles of the Fanconi anemia pathway in preserving genomic stability. Genes Dev. 2010, 24, 1680-1694. [CrossRef]

271. Boselli, M.; Lee, B.-H.; Robert, J.; Prado, M.A.; Min, S.-W.; Cheng, C.; Silva, M.C.; Seong, C.; Elsasser, S.; Hatle, K.M.; et al. An inhibitor of the proteasomal deubiquitinating enzyme USP14 induces tau elimination in cultured neurons. J. Biol. Chem. 2017, 292, 19209-19225. [CrossRef]

272. Palmer, A.L.; De Jong, A.; Leestemaker, Y.; Geurink, P.P.; Wijdeven, R.H.; Ovaa, H.; Dolan, B.P. Inhibition of the Deubiquitinase Usp14 Diminishes Direct MHC Class I Antigen Presentation. J. Immunol. 2018, 200, 928-936. [CrossRef]

273. Sha, B.; Chen, X.; Wu, H.; Li, M.; Shi, J.; Wang, L.; Liu, X.; Chen, P.; Hu, T.; Li, P. Deubiquitylatinase inhibitor b-AP15 induces c-Myc-Noxa-mediated apoptosis in esophageal squamous cell carcinoma. Apoptosis 2019, 24, 826-836. [CrossRef]

274. Verma, R.; Aravind, L.; Oania, R.; McDonald, W.H.; Yates, J.R., III; Koonin, E.V.; Deshaies, R.J. Role of Rpn11 Metalloprotease in Deubiquitination and Degradation by the 26S Proteasome. Science 2002, 298, 611-615. [CrossRef]

275. Perez, C.; Li, J.; Parlati, F.; Rouffet, M.; Ma, Y.; MacKinnon, A.L.; Chou, T.-F.; Deshaies, R.J.; Cohen, S.M.; Parlati, F.; et al. Discovery of an Inhibitor of the Proteasome Subunit Rpn11. J. Med. Chem. 2017, 60, 1343-1361. [CrossRef] [PubMed]

276. Lauinger, L.; Li, J.; Shostak, A.; Cemel, I.A.; Ha, N.; Zhang, Y.; Merkl, P.E.; Obermeyer, S.; Stankovic-Valentin, N.; Schafmeier, T.; et al. Thiolutin is a zinc chelator that inhibits the Rpn11 and other JAMM metalloproteases. Nat. Chem. Biol. 2017, 13, 709-714. [CrossRef] [PubMed]

277. Ott, C.A.; Baljinnyam, B.; Zakharov, A.V.; Jadhav, A.; Simeonov, A.; Zhuang, Z. Cell Lysate-Based AlphaLISA Deubiquitinase Assay Platform for Identification of Small Molecule Inhibitors. ACS Chem. Biol. 2017, 12, 2399-2407. [CrossRef] [PubMed]

278. Liu, Y.; Lashuel, H.A.; Choi, S.; Xing, X.; Case, A.; Ni, J.; Yeh, L.-A.; Cuny, G.D.; Stein, R.L.; Lansbury, P.T. Discovery of Inhibitors that Elucidate the Role of UCH-L1 Activity in the H1299 Lung Cancer Cell Line. Chem. Biol. 2003, 10, 837-846. [CrossRef]

279. Kooij, R.; Liu, S.; Sapmaz, A.; Xin, B.-T.; Janssen, G.M.C.; Van Veelen, P.A.; Ovaa, H.; Dijke, P.T.; Geurink, P. A Small-Molecule Activity-Based Probe for Monitoring Ubiquitin C-terminal Hydrolase L1 (UCHL1) Activity in Live Cells and Zebrafish Embryos. J. Am. Chem. Soc. 2020, 142, 16825-16841. [CrossRef]

280. Peddaboina, C.; Jupiter, D.; Fletcher, S.; Yap, J.L.; Rai, A.; Tobin, R.P.; Jiang, W.; Rascoe, P.; Rogers, M.K.N.; Smythe, W.R.; et al. The downregulation of Mcl-1 via USP9X inhibition sensitizes solid tumors to Bcl-xl inhibition. BMC Cancer 2012, 12, 541. [CrossRef] [PubMed]

281. Schwickart, M.; Huang, X.; Lill, J.R.; Liu, J.; Ferrando, R.; French, D.M.; Maecker, H.; O’Rourke, K.; Bazan, F.; Eastham-Anderson, J.; et al. Deubiquitinase USP9X stabilizes MCL1 and promotes tumour cell survival. Nat. Cell Biol. 2009, 463, 103-107. [CrossRef]

282. Kapuria, V.; Levitzki, A.; Bornmann, W.G.; Maxwell, D.; Priebe, W.; Sorenson, R.J.; Showalter, H.D.; Talpaz, M.; Donato, N.J. A novel small molecule deubiquitinase inhibitor blocks Jak2 signaling through Jak2 ubiquitination. Cell. Signal. 2011, 23, $2076-2085$. [CrossRef] [PubMed]

283. Wang, S.; Kollipara, R.K.; Srivastava, N.; Li, R.; Ravindranathan, P.; Hernandez, E.; Freeman, E.; Humphries, C.G.; Kapur, P.; Lotan, Y.; et al. Ablation of the oncogenic transcription factor ERG by deubiquitinase inhibition in prostate cancer. Proc. Natl. Acad. Sci. USA 2014, 111, 4251-4256. [CrossRef] [PubMed]

284. Li, S.; Zheng, H.; Mao, A.-P.; Zhong, B.; Li, Y.; Liu, Y.; Gao, Y.; Ran, Y.; Tien, P.; Shu, H.-B. Regulation of Virus-triggered Signaling by OTUB1- and OTUB2-mediated Deubiquitination of TRAF3 and TRAF6. J. Biol. Chem. 2010, 285, 4291-4297. [CrossRef] [PubMed]

285. Beck, A.; Vinik, Y.; Shatz-Azoulay, H.; Isaac, R.; Streim, S.; Jona, G.; Boura-Halfon, S.; Zick, Y. Otubain 2 is a novel promoter of beta cell survival as revealed by siRNA high-throughput screens of human pancreatic islets. Diabetologia 2013, 56, 1317-1326. [CrossRef]

286. Kudo, L.C.; Parfenova, L.; Vi, N.; Lau, K.; Pomakian, J.; Valdmanis, P.; Rouleau, G.A.; Vinters, H.V.; Wiedau-Pazos, M.; Karsten, S.L. Integrative gene-tissue microarray-based approach for identification of human disease biomarkers: Application to amyotrophic lateral sclerosis. Hum. Mol. Genet. 2010, 19, 3233-3253. [CrossRef] [PubMed]

287. Zhang, Z.; Du, J.; Wang, S.; Shao, L.; Jin, K.; Li, F.; Wei, B.; Ding, W.; Fu, P.; van Dam, H.; et al. OTUB2 Promotes Cancer Metastasis via Hippo-Independent Activation of YAP and TAZ. Mol. Cell 2019, 73, 7-21.e7. [CrossRef]

288. Mevissen, T.E.; Hospenthal, M.K.; Geurink, P.; Elliott, P.; Akutsu, M.; Arnaudo, N.; Ekkebus, R.; Kulathu, Y.; Wauer, T.; El Oualid, F.; et al. OTU Deubiquitinases Reveal Mechanisms of Linkage Specificity and Enable Ubiquitin Chain Restriction Analysis. Cell 2013, 154, 169-184. [CrossRef]

289. Resnick, E.; Bradley, A.; Gan, J.; Douangamath, A.; Krojer, T.; Sethi, R.; Geurink, P.P.; Aimon, A.; Amitai, G.; Bellini, D.; et al. Rapid Covalent-Probe Discovery by Electrophile-Fragment Screening. J. Am. Chem. Soc. 2019, 141, 8951-8968. [CrossRef]

290. Bednash, J.S.; Weathington, N.; Londino, J.; Rojas, M.; Gulick, D.L.; Fort, R.; Han, S.; McKelvey, A.C.; Chen, B.B.; Mallampalli, R.K. Targeting the deubiquitinase STAMBP inhibits NALP7 inflammasome activity. Nat. Commun. 2017, 8, 15203. [CrossRef]

291. Aleo, E.; Henderson, C.J.; Fontanini, A.; Solazzo, B.; Brancolini, C. Identification of New Compounds That Trigger ApoptosomeIndependent Caspase Activation and Apoptosis. Cancer Res. 2006, 66, 9235-9244. [CrossRef] 
292. Reiner, T.; Parrondo, R.; Pozas, A.D.L.; Palenzuela, D.; Perez-Stable, C. Betulinic Acid Selectively Increases Protein Degradation and Enhances Prostate Cancer-Specific Apoptosis: Possible Role for Inhibition of Deubiquitinase Activity. PLoS ONE 2013, 8 , e56234. [CrossRef]

293. D'Arcy, P.; Wang, X.; Linder, S. Deubiquitinase inhibition as a cancer therapeutic strategy. Pharmacol. Ther. 2015, 147, 32-54. [CrossRef]

294. Dixon, S.J.; Stockwell, B.R. Identifying druggable disease-modifying gene products. Curr. Opin. Chem. Biol. 2009, 13, 549-555. [CrossRef]

295. Russ, A.P.; Lampel, S. The druggable genome: An update. Drug Discov. Today 2005, 10, 1607-1610. [CrossRef]

296. Ottis, P.; Crews, C.M. Proteolysis-Targeting Chimeras: Induced Protein Degradation as a Therapeutic Strategy. ACS Chem. Biol. 2017, 12, 892-898. [CrossRef]

297. Cromm, P.M.; Crews, C.M. Targeted Protein Degradation: From Chemical Biology to Drug Discovery. Cell Chem. Biol. 2017, 24, 1181-1190. [CrossRef] [PubMed]

298. Toure, M.; Crews, C.M. Small-Molecule PROTACS: New Approaches to Protein Degradation. Angew. Chem. Int. Ed. 2016, 55, 1966-1973. [CrossRef]

299. Wells, J.A.; McClendon, C.L. Reaching for high-hanging fruit in drug discovery at protein-protein interfaces. Nat. Cell Biol. 2007, 450, 1001-1009. [CrossRef]

300. Pettersson, M.; Crews, C.M. PROteolysis TArgeting Chimeras (PROTACs)—Past, present and future. Drug Discov. Today Technol. 2019, 31, 15-27. [CrossRef] [PubMed]

301. Sakamoto, K.M.; Kim, K.B.; Kumagai, A.; Mercurio, F.; Crews, C.M.; Deshaies, R.J. Protacs: Chimeric molecules that target proteins to the Skp1-Cullin-F box complex for ubiquitination and degradation. Proc. Natl. Acad. Sci. USA 2001, 98, 8554-8559. [CrossRef]

302. Bondeson, D.P.; Mares, A.; Stafford-Smith, M.; Ko, E.; Campos, S.; Miah, A.H.; Mulholland, K.E.; Routly, N.; Buckley, D.L.; Gustafson, J.L.; et al. Catalytic in vivo protein knockdown by small-molecule PROTACs. Nat. Chem. Biol. 2015, 11, 611-617. [CrossRef] [PubMed]

303. Khan, S.; He, Y.; Zhang, X.; Yuan, Y.; Pu, S.; Kong, Q.; Zheng, G.; Zhou, D. PROteolysis TArgeting Chimeras (PROTACs) as emerging anticancer therapeutics. Oncogene 2020, 39, 4909-4924. [CrossRef] [PubMed]

304. Leiser, D.; Pochon, B.; Blank-Liss, W.; Francica, P.; Glück, A.A.; Aebersold, D.M.; Zimmer, Y.; Medová, M. Targeting of the MET receptor tyrosine kinase by small molecule inhibitors leads to MET accumulation by impairing the receptor downregulation. FEBS Lett. 2014, 588, 653-658. [CrossRef] [PubMed]

305. Spiegel, J.; Cromm, P.; Zimmermann, G.; Grossmann, T.; Waldmann, H. Small-molecule modulation of Ras signaling. Nat. Chem. Biol. 2014, 10, 613-622. [CrossRef]

306. An, S.; Fu, L. Small-molecule PROTACs: An emerging and promising approach for the development of targeted therapy drugs. EBioMedicine 2018, 36, 553-562. [CrossRef]

307. Yaron, A.; Hatzubai, A.; Davis, M.; Lavon, I.; Amit, S.; Manning, A.M.; Andersen, J.S.; Mann, M.; Mercurio, F.; Ben-Neriah, Y. Identification of the receptor component of the IkBa-ubiquitin ligase. Nature 1998, 396, 590-594. [CrossRef]

308. Sakamoto, K.M.; Kim, K.B.; Verma, R.; Ransick, A.; Stein, B.; Crews, C.M.; Deshaies, R. Development of Protacs to Target Cancer-promoting Proteins for Ubiquitination and Degradation. Mol. Cell. Proteom. 2003, 2, 1350-1358. [CrossRef]

309. Schneekloth, J.S.; Fonseca, F.N.; Koldobskiy, M.; Mandal, A.; Deshaies, R.; Sakamoto, K.M.; Crews, C.M. Chemical Genetic Control of Protein Levels: Selective in Vivo Targeted Degradation. J. Am. Chem. Soc. 2004, 126, 3748-3754. [CrossRef]

310. Schneekloth, A.R.; Pucheault, M.; Tae, H.S.; Crews, C.M. Targeted intracellular protein degradation induced by a small molecule: En route to chemical proteomics. Bioorg. Med. Chem. Lett. 2008, 18, 5904-5908. [CrossRef]

311. Ito, T.; Ando, H.; Suzuki, T.; Ogura, T.; Hotta, K.; Imamura, Y.; Yamaguchi, Y.; Handa, H. Identification of a Primary Target of Thalidomide Teratogenicity. Science 2010, 327, 1345-1350. [CrossRef]

312. Buckley, D.L.; Van Molle, I.; Gareiss, P.C.; Tae, H.S.; Michel, J.; Noblin, D.J.; Jorgensen, W.L.; Ciulli, A.; Crews, C.M. Targeting the von Hippel-Lindau E3 Ubiquitin Ligase Using Small Molecules to Disrupt the VHL/HIF-1 $\alpha$ Interaction. J. Am. Chem. Soc. 2012, 134, 4465-4468. [CrossRef]

313. Buckley, D.L.; Gustafson, J.L.; Van Molle, I.; Roth, A.G.; Tae, H.S.; Gareiss, P.C.; Jorgensen, W.L.; Ciulli, A.; Crews, C.M. SmallMolecule Inhibitors of the Interaction between the E3 Ligase VHL and HIF1 $\alpha$. Angew. Chem. Int. Ed. 2012, 51, 11463-11467. [CrossRef] [PubMed]

314. Van Molle, I.; Thomann, A.; Buckley, D.L.; So, E.C.; Lang, S.; Crews, C.M.; Ciulli, A. Dissecting Fragment-Based Lead Discovery at the von Hippel-Lindau Protein:Hypoxia Inducible Factor $1 \alpha$ Protein-Protein Interface. Chem. Biol. 2012, 19, 1300-1312. [CrossRef] [PubMed]

315. Galdeano, C.; Gadd, M.S.; Soares, P.; Scaffidi, S.; Van Molle, I.; Birced, I.; Hewitt, S.; Dias, D.M.; Ciulli, A. Structure-Guided Design and Optimization of Small Molecules Targeting the Protein-Protein Interaction between the von Hippel-Lindau (VHL) E3 Ubiquitin Ligase and the Hypoxia Inducible Factor (HIF) Alpha Subunit with in Vitro Nanomolar Affinities. J. Med. Chem. 2014, 57, 8657-8663. [CrossRef]

316. Buckley, D.L.; Raina, K.; Darricarrere, N.; Hines, J.; Gustafson, J.L.; Smith, I.E.; Miah, A.H.; Harling, J.D.; Crews, C.M. HaloPROTACS: Use of Small Molecule PROTACs to Induce Degradation of HaloTag Fusion Proteins. ACS Chem. Biol. 2015, 10, 1831-1837. [CrossRef] 
317. Zengerle, M.; Chan, K.-H.; Ciulli, A. Selective Small Molecule Induced Degradation of the BET Bromodomain Protein BRD4. ACS Chem. Biol. 2015, 10, 1770-1777. [CrossRef] [PubMed]

318. Belkina, A.; Denis, G.V. BET domain co-regulators in obesity, inflammation and cancer. Nat. Rev. Cancer 2012, 12, 465-477. [CrossRef] [PubMed]

319. Zuber, J.; Shi, J.; Wang, E.; Rappaport, A.R.; Herrmann, H.; Sison, E.A.; Magoon, D.; Qi, J.; Blatt, K.; Wunderlich, M.; et al. RNAi screen identifies Brd4 as a therapeutic target in acute myeloid leukaemia. Nat. Cell Biol. 2011, 478, 524-528. [CrossRef]

320. Baratta, M.G.; Schinzel, A.C.; Zwang, Y.; Bandopadhayay, P.; Bowman-Colin, C.; Kutt, J.; Curtis, J.; Piao, H.; Wong, L.C.; Kung, A.L.; et al. An in-tumor genetic screen reveals that the BET bromodomain protein, BRD4, is a potential therapeutic target in ovarian carcinoma. Proc. Natl. Acad. Sci. USA 2015, 112, 232-237. [CrossRef]

321. Raina, K.; Lu, J.; Qian, Y.; Altieri, M.; Gordon, D.; Rossi, A.M.K.; Wang, J.; Chen, X.; Dong, H.; Siu, K.; et al. PROTAC-induced BET protein degradation as a therapy for castration-resistant prostate cancer. Proc. Natl. Acad. Sci. USA 2016, 113, 7124-7129. [CrossRef] [PubMed]

322. Lu, J.; Qian, Y.; Altieri, M.; Dong, H.; Wang, J.; Raina, K.; Hines, J.; Winkler, J.D.; Crew, A.P.; Coleman, K.; et al. Hijacking the E3 Ubiquitin Ligase Cereblon to Efficiently Target BRD4. Chem. Biol. 2015, 22, 755-763. [CrossRef] [PubMed]

323. Winter, G.; Buckley, D.L.; Paulk, J.; Roberts, J.; Souza, A.; Dhe-Paganon, S.; Bradner, J.E. Phthalimide conjugation as a strategy for in vivo target protein degradation. Science 2015, 348, 1376-1381. [CrossRef]

324. Li, X.; Song, Y. Proteolysis-targeting chimera (PROTAC) for targeted protein degradation and cancer therapy. J. Hematol. Oncol. 2020, 13, 1-14. [CrossRef]

325. Ishikawa, M.; Tomoshige, S.; Demizu, Y.; Naito, M. Selective Degradation of Target Proteins by Chimeric Small-Molecular Drugs, PROTACs and SNIPERs. Pharmaceuticals 2020, 13, 74. [CrossRef]

326. Ocaña, A.; Pandiella, A. Proteolysis targeting chimeras (PROTACs) in cancer therapy. J. Exp. Clin. Cancer Res. 2020, 13, 50. [CrossRef] [PubMed]

327. Robb, C.M.; Contreras, J.I.; Kour, S.; Taylor, M.A.; Abid, M.; Sonawane, Y.A.; Zahid, M.; Murry, D.J.; Natarajan, A.; Rana, S. Chemically induced degradation of CDK9 by a proteolysis targeting chimera (PROTAC). Chem. Commun. 2017, 53, 7577-7580. [CrossRef]

328. Su, S.; Yang, Z.; Gao, H.; Yang, H.; Zhu, S.; An, Z.; Wang, J.; Li, Q.; Chandarlapaty, S.; Deng, H.; et al. Potent and Preferential Degradation of CDK6 via Proteolysis Targeting Chimera Degraders. J. Med. Chem. 2019, 62, 7575-7582. [CrossRef] [PubMed]

329. Brand, M.; Jiang, B.; Bauer, S.; Donovan, K.; Liang, Y.; Wang, E.S.; Nowak, R.P.; Yuan, J.C.; Zhang, T.; Kwiatkowski, N.; et al. Homolog-Selective Degradation as a Strategy to Probe the Function of CDK6 in AML. Cell Chem. Biol. 2019, 26, 300-306.e9. [CrossRef]

330. Zorba, A.; Nguyen, C.; Xu, Y.; Starr, J.; Borzilleri, K.; Smith, J.; Zhu, H.; Farley, K.A.; Ding, W.; Schiemer, J.; et al. Delineating the role of cooperativity in the design of potent PROTACs for BTK. Proc. Natl. Acad. Sci. USA 2018, 115, E7285-E7292. [CrossRef] [PubMed]

331. Jaime-Figueroa, S.; Buhimschi, A.D.; Toure, M.; Hines, J.; Crews, C.M. Design, synthesis and biological evaluation of Proteolysis Targeting Chimeras (PROTACs) as a BTK degraders with improved pharmacokinetic properties. Bioorg. Med. Chem. Lett. 2020, 30, 126877. [CrossRef]

332. Schiedel, M.; Herp, D.; Hammelmann, S.; Swyter, S.; Lehotzky, A.; Robaa, D.; Oláh, J.; Ovádi, J.; Sippl, W.; Jung, M. Chemically Induced Degradation of Sirtuin 2 (Sirt2) by a Proteolysis Targeting Chimera (PROTAC) Based on Sirtuin Rearranging Ligands (SirReals). J. Med. Chem. 2018, 61, 482-491. [CrossRef] [PubMed]

333. Yang, K.; Song, Y.; Xie, H.; Wu, H.; Wu, Y.-T.; Leisten, E.D.; Tang, W. Development of the first small molecule histone deacetylase 6 (HDAC6) degraders. Bioorg. Med. Chem. Lett. 2018, 28, 2493-2497. [CrossRef] [PubMed]

334. Yang, H.; Lv, W.; He, M.; Deng, H.; Li, H.; Wu, W.; Rao, Y. Plasticity in designing PROTACs for selective and potent degradation of HDAC6. Chem. Commun. 2019, 55, 14848-14851. [CrossRef]

335. Bassi, Z.I.; Fillmore, M.C.; Miah, A.H.; Chapman, T.D.; Maller, C.; Roberts, E.J.; Davis, L.C.; Lewis, D.E.; Galwey, N.W.; Waddington, K.E.; et al. Modulating PCAF/GCN5 Immune Cell Function through a PROTAC Approach. ACS Chem. Biol. 2018, 13, 2862-2867. [CrossRef] [PubMed]

336. McCoull, W.; Cheung, T.; Anderson, E.; Barton, P.; Burgess, J.; Byth, K.; Cao, Q.; Castaldi, M.P.; Chen, H.; Chiarparin, E.; et al. Development of a Novel B-Cell Lymphoma 6 (BCL6) PROTAC to Provide Insight into Small Molecule Targeting of BCL. ACS Chem. Biol. 2018, 13, 3131-3141. [CrossRef]

337. Zhou, H.; Bai, L.; Xu, R.; Zhao, Y.; Chen, J.; McEachern, D.; Chinnaswamy, K.; Wen, B.; Dai, L.; Kumar, P.; et al. StructureBased Discovery of SD-36 as a Potent, Selective, and Efficacious PROTAC Degrader of STAT3 Protein. J. Med. Chem. 2019, 62, 11280-11300. [CrossRef]

338. Bai, L.; Zhou, B.; Yang, C.-Y.; Ji, J.; McEachern, D.; Przybranowski, S.; Jiang, H.; Hu, J.; Xu, F.; Zhao, Y.; et al. Targeted Degradation of BET Proteins in Triple-Negative Breast Cancer. Cancer Res. 2017, 77, 2476-2487. [CrossRef]

339. Lai, A.C.; Toure, M.; Hellerschmied, D.; Salami, J.; Jaime-Figueroa, S.; Ko, E.; Hines, J.; Crews, C.M. Modular PROTAC Design for the Degradation of Oncogenic BCR-ABL. Angew. Chem. Int. Ed. 2016, 55, 807-810. [CrossRef] 
340. Gadd, M.S.; Testa, A.; Lucas, X.; Chan, K.-H.; Chen, W.; Lamont, D.J.; Zengerle, M.; Ciulli, A. Structural basis of PROTAC cooperative recognition for selective protein degradation Accession codes Atomic coordinates and structure factors for hsBrd4 BD2-MZ1-hsVHL-hsEloC-hsEloB have been deposited in the Protein Data Bank (PDB) under accession number. Nat. Chem. Biol. 2017, 13, 514-521. [CrossRef]

341. Crew, A.P.; Raina, K.; Dong, H.; Qian, Y.; Wang, J.; Vigil, D.; Serebrenik, Y.; Hamman, B.D.; Morgan, A.; Ferraro, C.; et al. Identification and Characterization of Von Hippel-Lindau-Recruiting Proteolysis Targeting Chimeras (PROTACs) of TANKBinding Kinase. J. Med. Chem. 2018, 61, 583-598. [CrossRef]

342. Gechijian, L.N.; Buckley, D.L.; Lawlor, M.A.; Reyes, J.; Paulk, J.; Ott, C.J.; Winter, G.E.; Erb, M.A.; Scott, T.G.; Xu, M.; et al. Functional TRIM24 degrader via conjugation of ineffectual bromodomain and VHL ligands. Nat. Chem. Biol. 2018, 14, 405-412. [CrossRef]

343. Burslem, G.M.; Song, J.; Chen, X.; Hines, J.; Crews, C.M. Enhancing Antiproliferative Activity and Selectivity of a FLT-3 Inhibitor by Proteolysis Targeting Chimera Conversion. J. Am. Chem. Soc. 2018, 140, 16428-16432. [CrossRef]

344. Kang, C.H.; Lee, D.H.; Lee, C.O.; Du Ha, J.; Park, C.H.; Hwang, J.Y. Induced protein degradation of anaplastic lymphoma kinase (ALK) by proteolysis targeting chimera (PROTAC). Biochem. Biophys. Res. Commun. 2018, 505, 542-547. [CrossRef]

345. Cromm, P.M.; Samarasinghe, K.T.G.; Hines, J.; Crews, C.M. Addressing Kinase-Independent Functions of Fak via PROTACMediated Degradation. J. Am. Chem. Soc. 2018, 140, 17019-17026. [CrossRef] [PubMed]

346. Han, X.; Wang, C.; Qin, C.; Xiang, W.; Fernandez-Salas, E.; Yang, C.-Y.; Wang, M.; Zhao, L.; Xu, T.; Chinnaswamy, K.; et al. Discovery of ARD-69 as a Highly Potent Proteolysis Targeting Chimera (PROTAC) Degrader of Androgen Receptor (AR) for the Treatment of Prostate Cancer. J. Med. Chem. 2019, 62, 941-964. [CrossRef]

347. Smith, B.; Wang, S.L.; Jaime-Figueroa, S.; Harbin, A.; Wang, J.; Hamman, B.D.; Crews, C.M. Differential PROTAC substrate specificity dictated by orientation of recruited E3 ligase. Nat. Commun. 2019, 10, 131. [CrossRef] [PubMed]

348. Nunes, J.; McGonagle, G.A.; Eden, J.; Kiritharan, G.; Touzet, M.; Lewell, X.; Emery, J.; Eidam, H.; Harling, J.D.; Anderson, N.A. Targeting IRAK4 for Degradation with PROTACs. ACS Med. Chem. Lett. 2019, 10, 1081-1085. [CrossRef] [PubMed]

349. Khan, S.; Zhang, X.; Lv, D.; Zhang, Q.; He, Y.; Zhang, P.; Liu, X.; Thummuri, D.; Yuan, Y.; Wiegand, J.S.; et al. A selective BCL-XL PROTAC degrader achieves safe and potent antitumor activity. Nat. Med. 2019, 25, 1938-1947. [CrossRef]

350. Zhang, X.; Thummuri, D.; Liu, X.; Hu, W.; Zhang, P.; Khan, S.; Yuan, Y.; Zhou, D.; Zheng, G. Discovery of PROTAC BCL-XL degraders as potent anticancer agents with low on-target platelet toxicity. Eur. J. Med. Chem. 2020, 192, 112186. [CrossRef]

351. Hines, J.; Lartigue, S.; Dong, H.; Qian, Y.; Crews, C.M. MDM2-Recruiting PROTAC Offers Superior, Synergistic Antiproliferative Activity via Simultaneous Degradation of BRD4 and Stabilization of p53. Cancer Res. 2019, 79, 251-262. [CrossRef] [PubMed]

352. Zhao, Q.; Lan, T.; Su, S.; Rao, Y. Induction of apoptosis in MDA-MB-231 breast cancer cells by a PARP1-targeting PROTAC small molecule. Chem. Commun. 2019, 55, 369-372. [CrossRef]

353. Li, Y.; Yang, J.; Aguilar, A.; McEachern, D.; Przybranowski, S.; Liu, L.; Yang, C.-Y.; Wang, M.; Han, X.; Wang, S. Discovery of MD-224 as a First-in-Class, Highly Potent, and Efficacious Proteolysis Targeting Chimera Murine Double Minute 2 Degrader Capable of Achieving Complete and Durable Tumor Regression. J. Med. Chem. 2019, 62, 448-466. [CrossRef] [PubMed]

354. Lu, M.; Liu, T.; Jiao, Q.; Ji, J.; Tao, M.; Liu, Y.; You, Q.; Jiang, Z. Discovery of a Keap1-dependent peptide PROTAC to knockdown Tau by ubiquitination-proteasome degradation pathway. Eur. J. Med. Chem. 2018, 146, 251-259. [CrossRef] [PubMed]

355. Zhang, X.; Crowley, V.M.; Wucherpfennig, T.G.; Dix, M.M.; Cravatt, B.F. Electrophilic PROTACs that degrade nuclear proteins by engaging DCAF16. Nat. Chem. Biol. 2019, 15, 737-746. [CrossRef]

356. Spradlin, J.N.; Hu, X.; Ward, C.C.; Brittain, S.M.; Jones, M.D.; Ou, L.; To, M.; Proudfoot, A.; Ornelas, E.; Woldegiorgis, M.; et al. Harnessing the anti-cancer natural product nimbolide for targeted protein degradation. Nat. Chem. Biol. 2019, 15, 747-755. [CrossRef] [PubMed]

357. Neklesa, T.; Snyder, L.B.; Willard, R.R.; Vitale, N.; Raina, K.; Pizzano, J.; Gordon, D.; Bookbinder, M.; Macaluso, J.; Dong, H.; et al. Abstract 5236: ARV-110: An androgen receptor PROTAC degrader for prostate cancer. Clin. Trials 2018, 78, 5236. [CrossRef]

358. Flanagan, J.; Qian, Y.; Gough, S.; Andreoli, M.; Bookbinder, M.; Cadelina, G.; Bradley, J.; Rousseau, E.; Willard, R.; Pizzano, J.; et al. Abstract P5-04-18: ARV-471, an oral estrogen receptor PROTAC degrader for breast cancer. Poster Sess. Abstr. 2019, 79, P5-04. [CrossRef]

359. Itoh, Y.; Ishikawa, M.; Naito, M.; Hashimoto, Y. Protein Knockdown Using Methyl Bestatin-Ligand Hybrid Molecules: Design and Synthesis of Inducers of Ubiquitination-Mediated Degradation of Cellular Retinoic Acid-Binding Proteins. J. Am. Chem. Soc. 2010, 132, 5820-5826. [CrossRef]

360. Naito, M.; Ohoka, N.; Shibata, N. SNIPERs-Hijacking IAP activity to induce protein degradation. Drug Discov. Today Technol. 2019, 31, 35-42. [CrossRef]

361. Itoh, Y.; Ishikawa, M.; Kitaguchi, R.; Sato, S.; Naito, M.; Hashimoto, Y. Development of target protein-selective degradation inducer for protein knockdown. Bioorg. Med. Chem. 2011, 19, 3229-3241. [CrossRef]

362. Okuhira, K.; Demizu, Y.; Hattori, T.; Ohoka, N.; Shibata, N.; Nishimaki-Mogami, T.; Okuda, H.; Kurihara, M.; Naito, M. Development of hybrid small molecules that induce degradation of estrogen receptor-alpha and necrotic cell death in breast cancer cells. Cancer Sci. 2013, 104, 1492-1498. [CrossRef]

363. Ohoka, N.; Morita, Y.; Nagai, K.; Shimokawa, K.; Ujikawa, O.; Fujimori, I.; Ito, M.; Hayase, Y.; Okuhira, K.; Shibata, N.; et al. Derivatization of inhibitor of apoptosis protein (IAP) ligands yields improved inducers of estrogen receptor $\alpha$ degradation. J. Biol. Chem. 2018, 293, 6776-6790. [CrossRef] 
364. Shibata, N.; Nagai, K.; Morita, Y.; Ujikawa, O.; Ohoka, N.; Hattori, T.; Koyama, R.; Sano, O.; Imaeda, Y.; Nara, H.; et al. Development of Protein Degradation Inducers of Androgen Receptor by Conjugation of Androgen Receptor Ligands and Inhibitor of Apoptosis Protein Ligands. J. Med. Chem. 2018, 61, 543-575. [CrossRef]

365. Ohoka, N.; Ujikawa, O.; Shimokawa, K.; Sameshima, T.; Shibata, N.; Hattori, T.; Nara, H.; Cho, N.; Naito, M. Different Degradation Mechanisms of Inhibitor of Apoptosis Proteins (IAPs) by the Specific and Nongenetic IAP-Dependent Protein Eraser (SNIPER). Chem. Pharm. Bull. 2019, 67, 203-209. [CrossRef] [PubMed]

366. Maniaci, C.; Hughes, S.J.; Testa, A.; Chen, W.; Lamont, D.J.; Rocha, S.; Alessi, D.R.; Romeo, R.; Ciulli, A. Homo-PROTACs: Bivalent small-molecule dimerizers of the VHL E3 ubiquitin ligase to induce self-degradation. Nat. Commun. 2017, 8, 1-14. [CrossRef] [PubMed]

367. Steinebach, C.; Lindner, S.; Udeshi, N.D.; Mani, D.C.; Kehm, H.; Köpff, S.; Carr, S.A.; Gütschow, M.; Krönke, J. Homo-PROTACs for the Chemical Knockdown of Cereblon. ACS Chem. Biol. 2018, 13, 2771-2782. [CrossRef]

368. Girardini, M.; Maniaci, C.; Hughes, S.J.; Testa, A.; Ciulli, A. Cereblon versus VHL: Hijacking E3 ligases against each other using PROTACs. Bioorg. Med. Chem. 2019, 27, 2466-2479. [CrossRef]

369. Lebraud, H.; Wright, D.; Johnson, C.N.; Heightman, T.D. Protein Degradation by In-Cell Self-Assembly of Proteolysis Targeting Chimeras. ACS Cent. Sci. 2016, 2, 927-934. [CrossRef]

370. Xue, G.; Wang, K.; Zhou, D.; Zhong, H.; Pan, Z. Light-Induced Protein Degradation with Photocaged PROTACs. J. Am. Chem. Soc. 2019, 141, 18370-18374. [CrossRef] [PubMed]

371. Pfaff, P.; Samarasinghe, K.T.G.; Crews, C.M.; Carreira, E.M. Reversible Spatiotemporal Control of Induced Protein Degradation by Bistable PhotoPROTACs. ACS Cent. Sci. 2019, 5, 1682-1690. [CrossRef] [PubMed]

372. Reynders, M.; Matsuura, B.S.; Bérouti, M.; Simoneschi, D.; Marzio, A.; Pagano, M.; Trauner, D. PHOTACs enable optical control of protein degradation. Sci. Adv. 2020, 6, 5064. [CrossRef]

373. Liu, J.; Chen, H.; Ma, L.; He, Z.; Wang, D.; Liu, Y.; Lin, Q.; Zhang, T.; Gray, N.; Kaniskan, H. Ümit; et al. Light-induced control of protein destruction by opto-PROTAC. Sci. Adv. 2020, 6, eaay5154. [CrossRef]

374. Moreau, K.; Coen, M.; Zhang, A.X.; Pachl, F.; Castaldi, M.P.; Dahl, G.; Boyd, H.; Scott, C.; Newham, P. Proteolysis-targeting chimeras in drug development: A safety perspective. Br. J. Pharmacol. 2020, 177, 1709-1718. [CrossRef]

375. Edmondson, S.D.; Yang, B.; Fallan, C. Proteolysis targeting chimeras (PROTACs) in 'beyond rule-of-five' chemical space: Recent progress and future challenges. Bioorg. Med. Chem. Lett. 2019, 29, 1555-1564. [CrossRef] [PubMed]

376. Watt, G.F.; Scott-Stevens, P.; Gaohua, L. Targeted protein degradation in vivo with Proteolysis Targeting Chimeras: Current status and future considerations. Drug Discov. Today Technol. 2019, 31, 69-80. [CrossRef] [PubMed]

377. Schapira, M.; Calabrese, M.F.; Bullock, A.N.; Crews, C.M. Targeted protein degradation: Expanding the toolbox. Nat. Rev. Drug Discov. 2019, 18, 949-963. [CrossRef]

378. Roy, R.D.; Rosenmund, C.; Stefan, M. Cooperative binding mitigates the high-dose hook effect. BMC Syst. Biol. 2017, 11, 74. [CrossRef] [PubMed]

379. Nowak, R.P.; DeAngelo, S.L.; Buckley, D.; He, Z.; Donovan, K.; An, J.; Safaee, N.; Jedrychowski, M.P.; Ponthier, C.M.; Ishoey, M.; et al. Plasticity in binding confers selectivity in ligand-induced protein degradation. Nat. Chem. Biol. 2018, 14, 706-714. [CrossRef] [PubMed]

380. Alabi, S.B.; Crews, C.M. Major advances in targeted protein degradation: PROTACs, LYTACs, and MADTACs. J. Biol. Chem. 2021, 296, 100647. [CrossRef] [PubMed]

381. Troup, R.I.; Fallan, C.; Baud, M.G.J. Current strategies for the design of PROTAC linkers: A critical review. Explor. Target. Anti-tumor Ther. 2020, 1, 273-312. [CrossRef]

382. Lu, G.; Middleton, R.E.; Sun, H.; Naniong, M.; Ott, C.J.; Mitsiades, C.S.; Wong, K.-K.; Bradner, J.E.; Kaelin, W.G., Jr. The Myeloma Drug Lenalidomide Promotes the Cereblon-Dependent Destruction of Ikaros Proteins. Science 2014, 343, 305-309. [CrossRef] [PubMed]

383. Krönke, J.; Fink, E.C.; Hollenbach, P.W.; Macbeth, K.J.; Hurst, S.N.; Udeshi, N.D.; Chamberlain, P.P.; Mani, D.R.; Man, H.W.; Gandhi, A.K.; et al. Lenalidomide induces ubiquitination and degradation of CK1 $\alpha$ in del(5q) MDS. Nature 2015, 523, 183-188. [CrossRef] [PubMed]

384. Pan, B.; Lentzsch, S. The application and biology of immunomodulatory drugs (IMiDs) in cancer. Pharmacol. Ther. 2012, 136, 56-68. [CrossRef]

385. Fischer, E.S.; Böhm, K.; Lydeard, J.R.; Yang, H.; Stadler, M.B.; Cavadini, S.; Nagel, J.; Serluca, F.; Acker, V.; Lingaraju, G.M.; et al. Structure of the DDB1-CRBN E3 ubiquitin ligase in complex with thalidomide. Nat. Cell Biol. 2014, 512, 49-53. [CrossRef]

386. Rasco, D.W.; Papadopoulos, K.P.; Pourdehnad, M.; Gandhi, A.K.; Hagner, P.R.; Li, Y.; Wei, X.; Chopra, R.; Hege, K.; DiMartino, J.F.; et al. A First-in-Human Study of Novel Cereblon Modulator Avadomide (CC-122) in Advanced Malignancies. Clin. Cancer Res. 2018, 25, 90-98. [CrossRef]

387. Bjorklund, C.C.; Kang, J.; Amatangelo, M.; Polonskaia, A.; Katz, M.; Chiu, H.; Couto, S.; Wang, M.; Ren, Y.; Ortiz, M.; et al. Iberdomide (CC-220) is a potent cereblon E3 ligase modulator with antitumor and immunostimulatory activities in lenalidomideand pomalidomide-resistant multiple myeloma cells with dysregulated CRBN. Leukemia 2020, 34, 1197-1201. [CrossRef]

388. Han, T.; Goralski, M.; Gaskill, N.; Capota, E.; Kim, J.; Ting, T.C.; Xie, Y.; Williams, N.S.; Nijhawan, D. Anticancer sulfonamides target splicing by inducing RBM39 degradation via recruitment to DCAF15. Science 2017, 356, eaal3755. [CrossRef] 
389. Dauvois, S.; Danielian, P.S.; White, R.; Parker, M.G. Antiestrogen ICI 164, 384 Reduces Cellular Estrogen Receptor Content by Increasing Its Turnover. Proc. Natl. Acad. Sci. USA 1992, 89, 4037-4041. [CrossRef]

390. Xie, T.; Lim, S.M.; Westover, K.D.; Dodge, M.E.; Ercan, D.; Ficarro, S.B.; Udayakumar, D.; Gurbani, D.; Tae, H.S.; Riddle, S.M.; et al. Pharmacological targeting of the pseudokinase Her3. Nat. Chem. Biol. 2014, 10, 1006-1012. [CrossRef] [PubMed]

391. Gustafson, J.L.; Neklesa, T.K.; Cox, C.S.; Roth, A.G.; Buckley, D.L.; Tae, H.S.; Sundberg, T.B.; Stagg, D.; Hines, J.; McDonnell, D.P.; et al. Small-Molecule-Mediated Degradation of the Androgen Receptor through Hydrophobic Tagging. Angew. Chem. Int. Ed. 2015, 54, 9659-9662. [CrossRef]

392. Portnoff, A.D.; Stephens, E.A.; Varner, J.D.; DeLisa, M.P. Ubiquibodies, Synthetic E3 Ubiquitin Ligases Endowed with Unnatural Substrate Specificity for Targeted Protein Silencing. J. Biol. Chem. 2014, 289, 7844-7855. [CrossRef] [PubMed]

393. Long, M.J.C.; Gollapalli, D.R.; Hedstrom, L. Inhibitor Mediated Protein Degradation. Chem. Biol. 2012, 19, 629-637. [CrossRef]

394. Kanner, S.A.; Shuja, Z.; Choudhury, P.; Jain, A.; Colecraft, H.M. Targeted deubiquitination rescues distinct trafficking-deficient ion channelopathies. Nat. Methods 2020, 17, 1245-1253. [CrossRef]

395. Carvajal, L.A.; Ben Neriah, D.; Senecal, A.; Benard, L.; Thiruthuvanathan, V.; Yatsenko, T.; Narayanagari, S.-R.; Wheat, J.C.; Todorova, T.I.; Mitchell, K.; et al. Dual inhibition of MDMX and MDM2 as a therapeutic strategy in leukemia. Sci. Transl. Med. 2018, 10, eaao3003. [CrossRef]

396. Ernst, A.; Avvakumov, G.; Tong, J.; Fan, Y.; Zhao, Y.; Alberts, P.; Persaud, A.; Walker, J.R.; Neculai, A.-M.; Neculai, D.; et al. A Strategy for Modulation of Enzymes in the Ubiquitin System. Science 2013, 339, 590-595. [CrossRef] [PubMed]

397. Ernst, A. Engineering ubiquitin to modulate the ubiquitin proteosome system. Cell Cycle 2013, 12, 1651-1652. [CrossRef] [PubMed]

398. Zhang, Y.; Zhou, L.; Rouge, L.; Phillips, A.H.; Lam, C.; Liu, P.; Sandoval, W.; Helgason, E.; Murray, J.M.; E Wertz, I.; et al. Conformational stabilization of ubiquitin yields potent and selective inhibitors of USP7. Nat. Chem. Biol. 2012, 9, 51-58. [CrossRef]

399. Zhang, W.; Sartori, M.A.; Makhnevych, T.; Federowicz, K.E.; Dong, X.; Liu, L.; Nim, S.; Dong, A.; Yang, J.; Li, Y.; et al. Generation and Validation of Intracellular Ubiquitin Variant Inhibitors for USP7 and USP10. J. Mol. Biol. 2017, 429, 3546-3560. [CrossRef]

400. Garg, P.; Ceccarelli, D.F.; Keszei, A.F.; Kurinov, I.; Sicheri, F.; Sidhu, S.S. Structural and Functional Analysis of Ubiquitin-based Inhibitors That Target the Backsides of E2 Enzymes. J. Mol. Biol. 2020, 432, 952-966. [CrossRef]

401. LeBlanc, N.; Mallette, E.; Zhang, W. Targeted modulation of E3 ligases using engineered ubiquitin variants. FEBS J. 2021, 288, 2143-2165. [CrossRef] [PubMed] 